\title{
HOUSE: A PRACTICAL MANUAL FOR FITTER, HAPPIER, AND MORE PRODUCTIVE LIVING
}

\author{
YUTONG LIU
}

A THESIS SUBMITTED TO THE FACULTY OF GRADUATE AND POSTDOCTORAL AFFAIRS IN PARTIAL FULFILLMENT OF THE REQUIREMENTS FOR THE DEGREE OF MASTER IN ARCHITECTURE PROFESSIONAL

AZRIELI SCHOOL OF ARCHITECTURE \& URBANISM

CARLETON UNIVERSITY, OTTAWA, ONTARIO

YUTONG LIU @2013 
Library and Archives

Canada

Published Heritage

Branch

395 Wellington Street

Ottawa ON K1A ON4

Canada
Bibliothèque et

Archives Canada

Direction du

Patrimoine de l'édition

395 , rue Wellington

Ottawa ON K1A ON4

Canada
Your file Votre référence

ISBN: 978-0-494-94583-4

Our file Notre référence

ISBN: $978-0-494-94583-4$
NOTICE:

The author has granted a nonexclusive license allowing Library and Archives Canada to reproduce, publish, archive, preserve, conserve, communicate to the public by telecommunication or on the Internet, loan, distrbute and sell theses worldwide, for commercial or noncommercial purposes, in microform, paper, electronic and/or any other formats.

The author retains copyright ownership and moral rights in this thesis. Neither the thesis nor substantial extracts from it may be printed or otherwise reproduced without the author's permission.
AVIS:

L'auteur a accordé une licence non exclusive permettant à la Bibliothèque et Archives Canada de reproduire, publier, archiver, sauvegarder, conserver, transmettre au public par télécommunication ou par l'Internet, prêter, distribuer et vendre des thèses partout dans le monde, à des fins commerciales ou autres, sur support microforme, papier, électronique et/ou autres formats.

L'auteur conserve la propriété du droit d'auteur et des droits moraux qui protege cette thèse. $\mathrm{Ni}$ la thèse ni des extraits substantiels de celle-ci ne doivent être imprimés ou autrement reproduits sans son autorisation.
In compliance with the Canadian Privacy Act some supporting forms may have been removed from this thesis.

While these forms may be included in the document page count, their removal does not represent any loss of content from the thesis.
Conformément à la loi canadienne sur la protection de la vie privée, quelques formulaires secondaires ont été enlevés de cette thèse.

Bien que ces formulaires aient inclus dans la pagination, il n'y aura aucun contenu manquant. 
<smiles>C1CC1</smiles> 


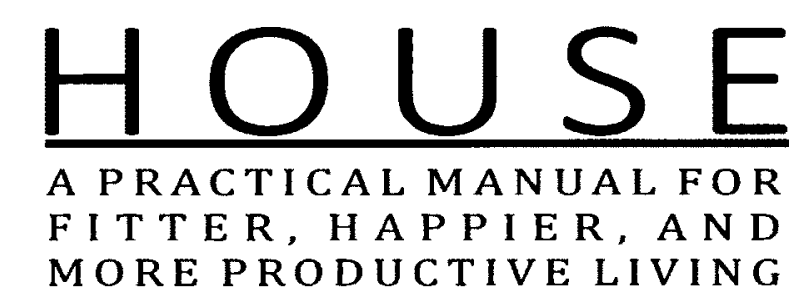


SHIRLEY YUTONG LIU COPYRIGHT (C) 2013 OTTAWA

THESIS SUBMITTED TO AZRIELI SCHOOL OF ARCHITECTURE AND URBANISM, CARLETON UNIVERSITY, OTTAWA, ONTARIO, CANADA

IN PARTIAL FULFILMENT OF THE REQUIREMENTS FOR THE DEGREEOFMASTERSOFARCHITECTURE(M.ARCHPROFESSIONAL) 
first of all,

I would like to thank those who supported me on achieving this level of living and learning.

my supervisor Roger Connah, who let me act, play, and be,

my family, who believed in me.

my friends, who shared insights, and

my cat, who stayed by my side all along. 


\section{A B S T R A C T}

Today we are "demanding accommodations of all kinds, moving at ever greater speeds, communicating over vast distances in no time at all, and urbanizing at astonishing densities." Such means of building is aimed to fulfill our ways of spending and consuming, but is this approach fit to sustaining our ways of thinking and living?

I hereby wish to imagine a HOUSE that provides the dwellers with a set of basic and advanced survival skills for a fit and happy mentality. "It is the contention of this manual that only through the restored opportunities for first-hand experience that HOUSE gives can health be brought back to the world of the mass culture."2 


\section{OPEN HOUSE THE ONE THAT FITS IN YOUR TIGHT LIEE TIME LINE}

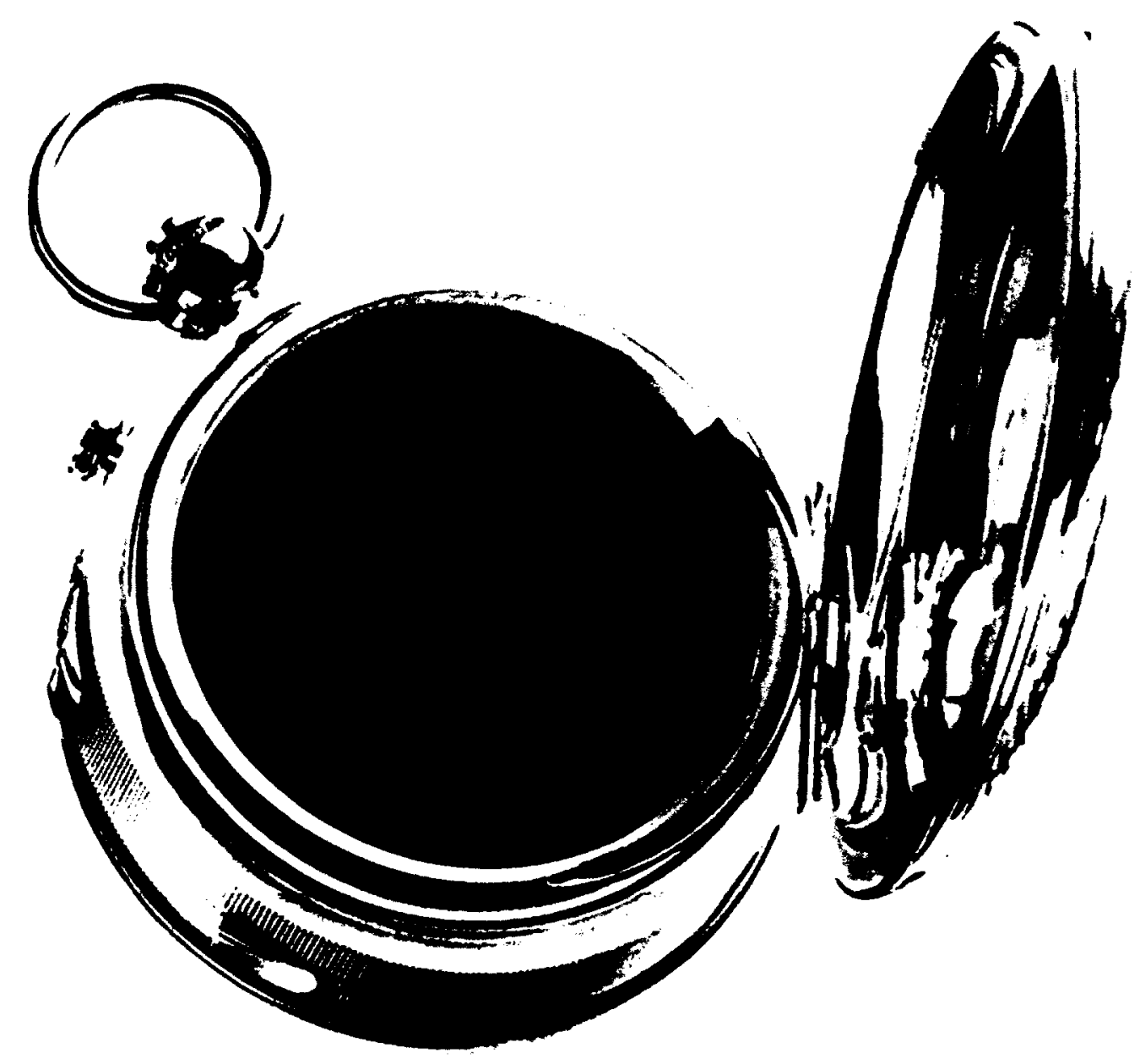


PROLOGUE

ACT 1 HOST'S SPEECH

o. WELCOMING

1. $V|S| O N$ PROPOSITION OBSERVATION DEDUCTION

CONSTRUCTION

INVITATION
HOUSE MOTTO: FITTER HAPPIER MORE PRODUCTIVE NORM•ODERN BUILDING

HOUSING DEVELOPMENT:VERTICAL/HORIZONTAL PRE-FAB PRE(TTY)-FAST PRE(TTY)-FAT CRITICAL REGIONALISM

THE VISIT
17 18 19 21 28 36

ACT 2 THE VISIT

EPILOGUE 81

CONCLUSION

POSTSCRIPT BIBLIOGRAPHY 


\section{USERS GUIDE TO ACT 1}

O B J E C T I V E

EXISTING DISCOURSE

\section{DEFINITION}
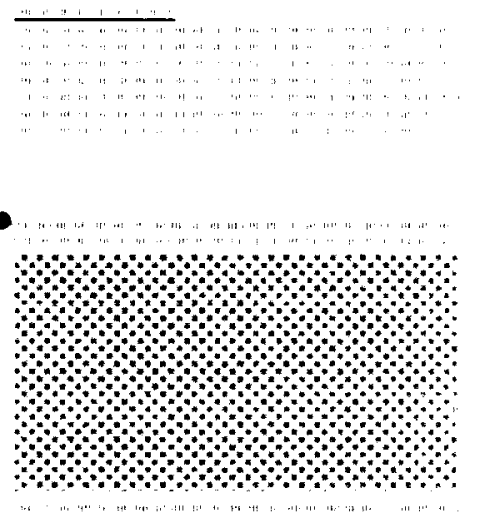

N $D=T$
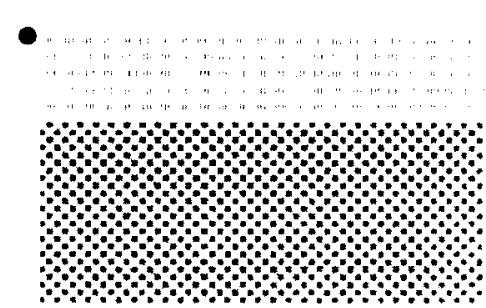

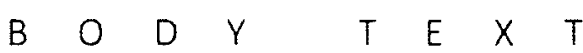

MAIN STREAM OF THE NARRATIVE

\section{(AII VISUALS BY AUTHOR UNIESS OTHERWISE STATED)}

H: (1):

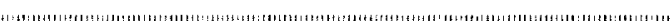
(1). -

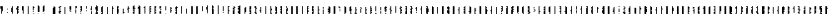

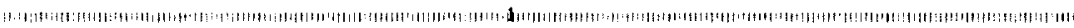
年 Ut.

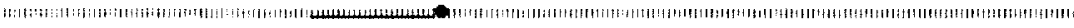

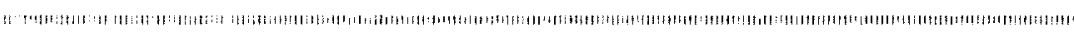

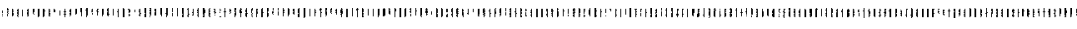
(1):เ

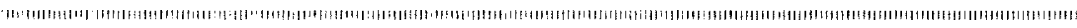
.

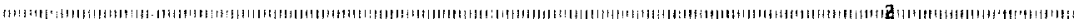
. ㄱ. -

(1).

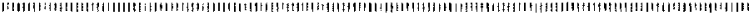
"16.1

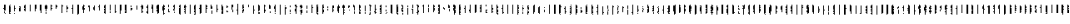
41

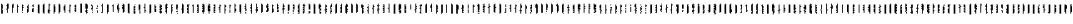

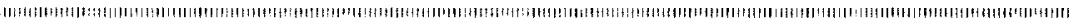

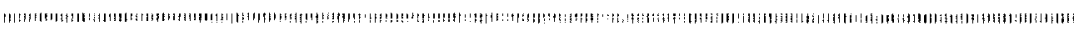

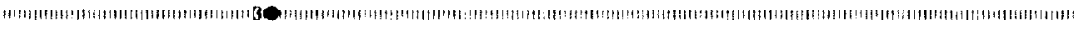

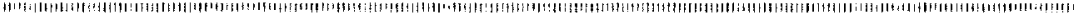
"1: 1.

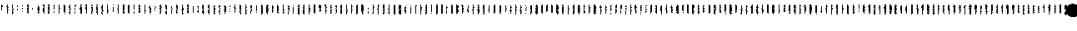

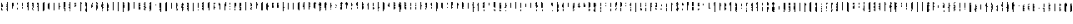
(1)

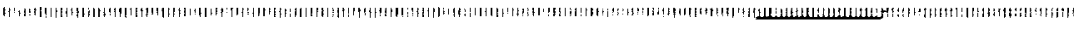

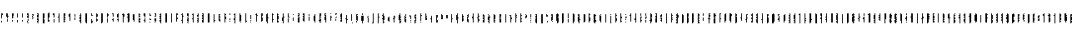

"1.1 19 1. 1.+1 20 31 4.

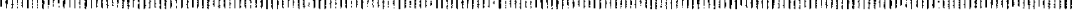
ер " מוד

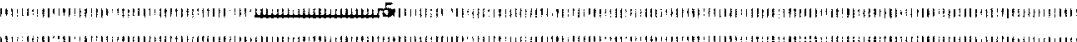
(2) "月.
$S U B$ J E C T I V E AUTHOR'S COMMENTARY

I MAGES / DIAGRAMS CAL VISUALS BY AUTHOR UNHESS OTHERWSE SWNED)

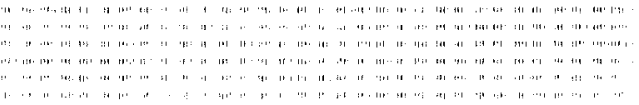




\section{INTRODUCTION}

In the manner of an Open House event, I present to you a medium density, medium rise residential complex project positioned in Centretown, Ottawa, based on the theme: fitter, happier, and more productive living. I will first set the field of vision with a brief background of my beliefs and motivation behind the stage under the subject: personal space. I will then open up the discussion in Act 1 where the theoretical foundation of the project is established upon the existing discourse. Having examined the precipitation of quantity and speed in today's design and production, I propose a compromised performance that is best suited for unique crowds of individuals taking off on a fitted pace and taking place in a fitted space. Following the theme: fitter, happier, and more productive, the project acts closely to each norm, from young to old, in attempt to raise individual responsibility and collective respect as a part and as a whole to the city. The project HOUSE in Act 2 illustrates all components of private, private/public, and public realms, exploring detailed fun!ctions in relation to our body language.

We will have plenty of room for discussion and further vision after the acts. This proposal shows only a few selections of mode we can meditate, so let us together swim in the imagination to discover the forgotten, the overlooked, the misused, and the unknown. 


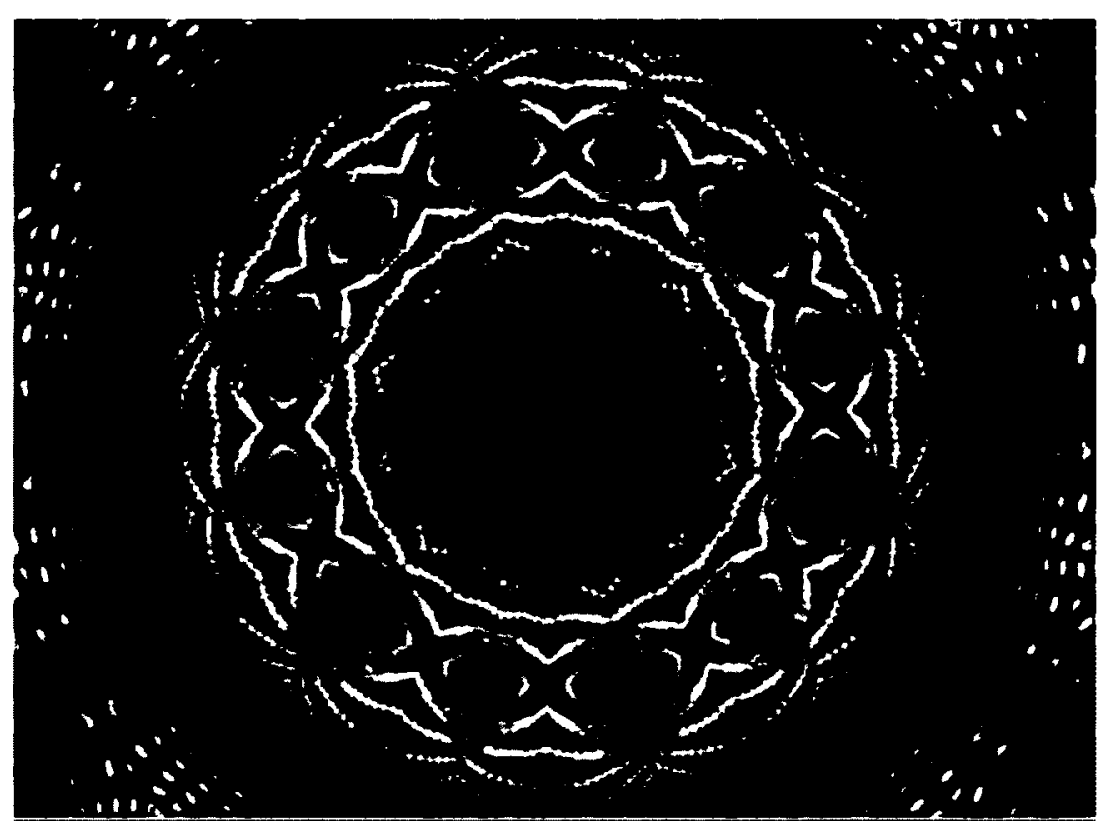

'THE KALEIDOSCOPE OF BRILLIANT COLOURS SPINS INTO THE MONOCHROME GREY' 
Overstimulation at the high, loud, fastend of the spectrum of experience, and deprivation at the low, quiet, slow end is robbing man of balanced variety. Attention is focused largely on the conspicuous dramatic inessentials: the new records, the fastest race, the highest building, the brightest lights, the farthest shot, the biggest audience, the largest fortune. The apparent increase in variety in our wealthy, industrialized society may turn out to be a new form of monotony of mass-produced commodities. More and more becomes less and less, and mere quantity and repetition of individually stimulating events kills their effectiveness. The kaleidoscope of brilliant colours spins into the monochrome grey of the colour wheel. It may be that the uniformity of the 'air-conditioned nightmare' fatigues both mind and body, that under such conditions the vital side of human life degenerates. 


\section{P R O L G U E}

"A large portion of our lives-working, sleeping, playing -is spent in buildings: buildings over whose design and construction we have little or no control; buildings whose effect upon our health and happiness is only obscurely understood." "Good design becomes a meaningless tautology if we consider that man will be reshaped to fit whatever environment he creates." ${ }^{2}$ Where we miss the point is at the initial vision: not so much what sort of environment we want, but what sort of man we want. In order to shape our space we must know how we want to shape ourselves. (By how, I do not only mean by an exact method of executing certain physiques, like controlling one's height and weight with devices, but rather by a whole picture of the way we want to behave and feel, such as attitude and perception.) In this manual, I attempt to approach a building not as a product but as an extension of our bodies acting in conscious or subconscious dimensions. 
We ask ourselves: do we live well? It is sort of a rhetorical question, but let us approach this from the following three points of view to diagnose our way of living to be fitter, happier and more productive. 1) Physical well-being within our personal space and time-frame (good appetite and good metabolism); 2) Awareness of such physical well-being which gives the mind positive signals and therefore psychological well-being (good attitude and good vision); 3) Overall performance of generating and sustaining energy in the cycle of thoughts and actions (good pace, good influence).

PERSONAL SPACE:

REFLECTS TWO USAGES OF THE TERM. THE FIRST REFERS TO THE EMOTIONALLY CHARGED ZONE AROUND EACH PERSON, SOMETIMES DESCRIBED AS A SOAP BUBBLE OR AURA, WHICH HELPS TO REGULATE THE SPACING OF INDIVIDUALS. THE SECOND USAGE REFERS TO THE PROCESSES BY WHICH PEOPLE MARK OUT AND PERSONALIZE THE SPACES THEY INHABIT. ${ }^{1}$ PERSONAL SPACE IS NOT NECESSARILY SPHERICAL IN SHAPE, NOR DOES IT EXTEND EQUALLY IN ALL DIRECTIONS. THERE ARE MAJOR DIFFERENCES BETWEEN CULTURES IN THE DISTANCES THAT PEOPLE MAINTAIN.

1 SOMMER PREFACE $V I I$

2 SOMMER 26.

TIME:

NEW MODE OF PRODUCTION OF TERRITORY ANDTHEORYBODY ANDMIND, THEREFORE REPLACING THE MODERNIST PRODUCTION OF SPACE (ACCORDING TO HENRI LEFEBVRE). NEITHER SPACE NOR TIME ARE NATURAL, BUT ARE RATHER SUBJECTED TO ARTIFICIAL PROCESSES OF CHANGE, TEMPORIZATION, AND MODIFICATION. TIME IS NOT A NATURAL DIMENSION, BUT ONE IN SYNCHRONICITY WITH OUR PSYCHOLOGICAL PERCEPTION OF TIME.

MARINA GRZNIC. TIME" IN ATLS OF TRANSFORMATON ZURICH: RRPRANGIER, 2O1O.FE12
Of course, an individual's level of well-being depends on where one stands in relation to where one wants to stand in the picture, and the effort of moving toward it. To start with, one can examine the familiar, personal space in order to first recognize how one occupies, perceives, and values the surrounding environment (of which, an immediate case would be one's house). Some of us get a big house and fill it up with things, while some find their own flow of time and span of space to float in, and some are comfortable soaking in the pool of societal standards and expectations. However, there are some who get a big house but cannot fill it up or cannot feel proportional with their properties; there are some who get spun off the track of the system and have hard time catching up with the crowd or finding the way home. As long as one is aware and in control, the state of well-being is up to each individual to decide, but for those who hold a slight doubt or discomfort in how they are, this manual might be good night reading.

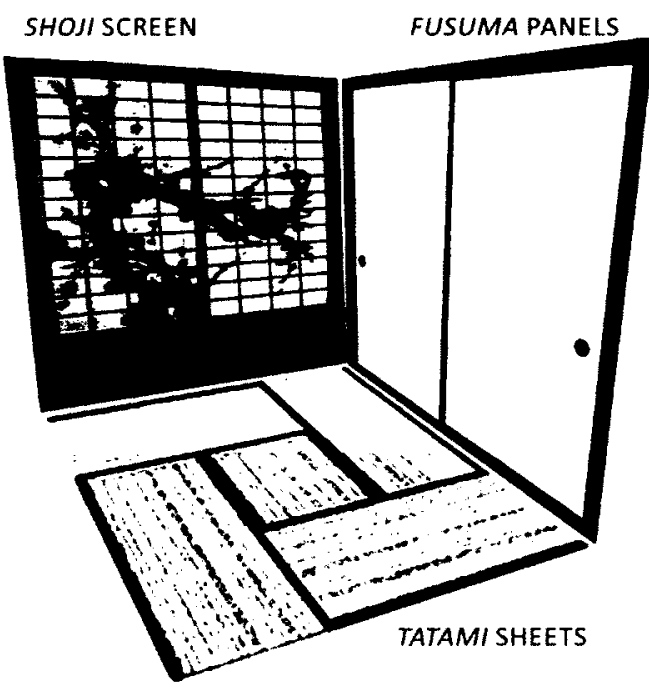

- I WAS RAISED IN A HOUSE COMPOSED OF 24 UNITS OF TATAMI WITH FUSUMA PANELS (WITHIN THE INTERIOR) AND SHOJ SCREENS (WITH-OUT TO THE PXTE WITH EACH FACE AND EDGE CAN BE FOLDED AND UNFOIDED INTO ANY KIND OF VOLUME AS I WANTED. THE SMAU HOUSE DID NOT FEEL SMALL ASI GREW ASIF THE HOUSE GREW WITH MY SENSES AND SENTIMENTS EVERY ELEMENT SO DELICATE YET FIRM-ESSENTIALIY WOOD WOOD PULP AND STRAWS WAS TRANSPARENT IN ITS PRESENCE AND FUNCTIONALITY, IT OFFERED SEASONAL COLOURS, TEMPERATURE AND ATMOSPHERE. THROUGH TS VISIOLEINVISIBLE BOUNDARIES, PERSONAL SPACES OF THE FAMILY AND NEIGHBOURS ARE FITERED OF THE FAMILY AND NEIGHBOURS ARE FITERED TO CARE AND RESPECT OTHERS' PERSONAL SPACES BEFORE MY OWN. 
Before we proceed into the practical manual of shaping the surrounding environment, let us remind ourselves of personal space as the base to establish house upon.

AS DESCRIBED bY TADAO ANDO WITH THE TERM SHINTAI, 'MAN ARTICULATES THE WORLD THROUGH BODY AND THE

ADOLF LOOS IN HIS ARCHITEKTUR 1910 STATED: ICALL CULTURE, THAT BALANCE OF INNER AND OUTER MAN, WHICH ALONE CAN GUARANTEE REASONABLE THOUGHT AND ACTION.'

BOUNDARY:

BOUNDARY IS NOT WHERE THINGS STOP BUT WHERE THINGS START THEIR PRESENCE.

ANCIENT GREEK PHILOSOPHY

MARTIN HEIDEGGER ARGUES THAT THE PHENOMENOLOGICAL ESSENCE OF A SPACE/PLACE DEPENDS UPON THE CONCRETE, CLEARLY DEFINED NATURE OF ITS BOUNDARY, AND THAT ETYMOLOGICALLY THE GERMAN GERUND BUILDING IS CLOSELY LINKED WITH THE ARCHAIC FORMS OF BEING, CULTIVATING AND DWELLING, WHERE ITS CONDITION CAN ONLY TAKE PLACE IN A DOMAIN THAT IS CLEARLY BOUNDED

KENNETH FRAMPTON. 'TOWARDS A CRITICAL REGGONALISM: SIX POINTS FOR AN ARCHITECTURE OF RESISTANCE' IN THE ANTT-AESTHETIC: ESSAYS
ON POSTMODERN CULUURE. ED. FOSTER. H. NEW
YORK: THE NEW PRESS, 1998. P27.
Personal space is shaped by the geographical and cultural environment of one's upbringing. One's reaction to and relationship with the surrounding objects and bodies are founded upon the habitual (invisible) boundaries associated with the personal space. This personalspace then leads to shaping one's perception, where the body and mind are in sync and aware of each other when being in contrast with an external force or information and/or realizing an internal becoming of self.

Space is described by the kanji character ma, containing the meanings of: room, space, void, duration, distance, pause, which involves the notion of time and space in a relation or together as a single concept. $M a$ is derived from two primary characters: the outer illustrating a gate or entrance; the inner illustrating the sun or day. A void inscribed by a form of boundary is illuminated. The boundary traditionally is often open or flexible in its physical and visual transparency, allowing cyclic and dynamic movement of bodies, air and light alongside the boundary; hence the centre of the room becomes the focus, the calm and the still, where individuals gather and face each other. The figurative ma character continues to remind us today of the primary conditions of dwelling, and from that origin, all the possibilities of which a white origami paper box is capable of becoming, and for us dwellers, being.

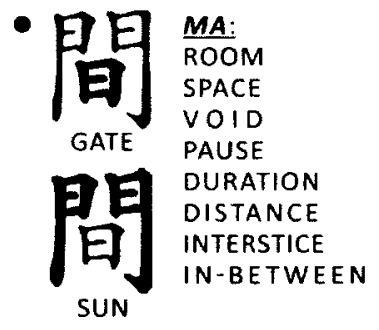


Now you have been invited to the Open House event, where you will be

shown step by step through the HOUSE. You will be presented with a

manual, and your choice of a chair, but you are welcome to bring your

very own, or you may stand on your feet, hands or head as you please.

The event will be followed by an open discussion. 


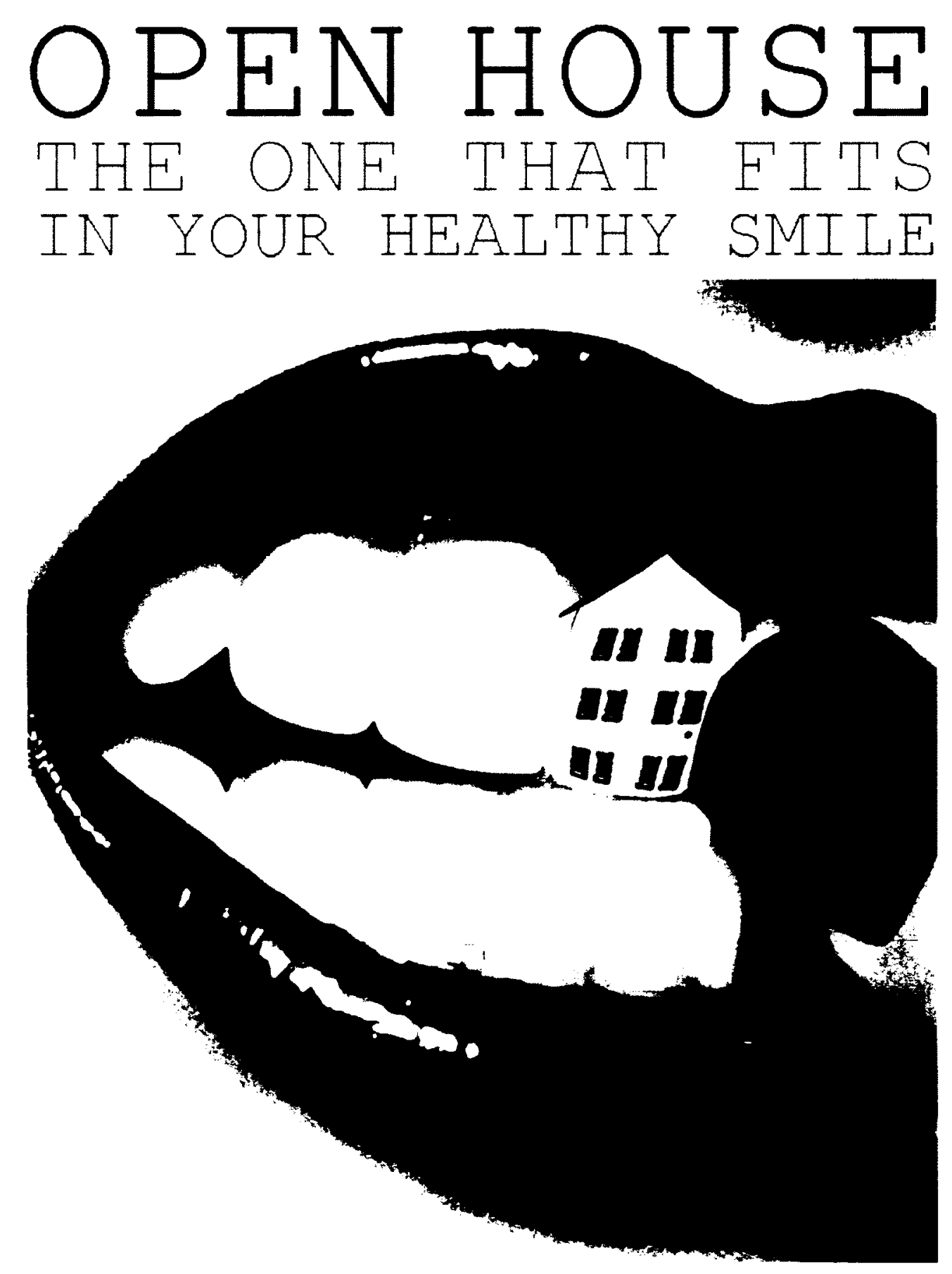




\section{ACT 1 HOST'S SPEECH}

0. WELCOM IN G HOUSE

Welcome to the HOUSE.

(Fill in the with a word or more, your own name, your favourite number, a picture, or leave it as you please... for 1 do not wish to impose an ideal upon the HOUSE and its inhabitants, but only wish to deliver an idea of a house as an open discussion to the inhabitants. You may also erase the title and replace entirely with home, in the future...)

We will together walk through the HOUSE first with the background information on housing industry, and then with attention to details on experiential moments of the HOUSE. Along the way, we will have discussions on some of the on-going topics of today's living and thinking, including: modern perception of time and space, habits and behaviour,

\section{HOME:}

BROUGHT TOGETHER THE MEANINGS OF HOUSE AND OF HOUSEHOLD, OF DWELUNG AND OF REFUGE, OF OWNERSHIP AND OF AFFECTION. HOME MEANT THE HOUSE, BUT ALSO EVERYTHING THAT WAS IN IT AND AROUND $\pi$, AS WELL AS THE PEOPLE, AND THE SENSE OF SATISFACTION AND CONTENTMEN TITAL THESECONVEYED. APHYSICAL PLACE AND ASENSE OF BEING. dimensions, development patterns...... (and further more subjects may be submitted by the guests).

Let's examine how the HOUSE's agents: intentions and purposes, functions and effects could or would advance the inhabitants' behavioural psychology, and how the both actors contribute to a fitter, happier, and more productive living.

Thank you for your participation. 


\section{VISION}

FITTER HAPPIER MORE PRODUCTIVE

RADIOHEAD, FITTER HAPPIER.

THE LYRICS CONSISTS OF A LIST OF $1990^{\circ} S$ COLLOQUIALISMS; THE 50 PHRASES COVERING A RANGE OF ISSUES FROM HEALTH AND PRACTICAL CONCERNS TO MORALITY AND SPIRITUAL MATTERS-A SURVVVAL'S KIT TO CONTEMPORARY LIVING. THE VOICE WAS GENERATED BY THE MACINTOSH COMPUTER SIMPLETEXT APPLICATION. SONGFACTS HITP:/AWWUSONGFACTSCOMM/DETAIL

\section{PRAGMATISM}

MOVEMENT CONSISTING OF VARYING BUT ASSOCATED THEORIES, DISTINGUISHED OF AN IDEA OR A PROPOSTON LIES IN ITS OBSERVABI EPRACTICAL CONSEOUENCES

THE AMERTCAN HERTAGE OKCTONAPY OF THE ENGLISH

\section{IDEALISM:}

PHILOSOPHICAL SENSE, IN WHIOH, IDEAS ARE HELD TO UNDERUE OR TO FORM ALL REAUTY II) ITS MDER MODERN SENSE OF A WAY OF THINKING IN WHICH SOME HIGHER OR BETIER STATE IS PROJECTED AS A WAY OF JUDGING CONDUCTOROF INDICATING ACTON. (ONE OF THE CRITCAL DIFFICUITES OF SENSE II) IS THAT, ESPECAUY IN SOME OF ITS DERMED WORDS, $I$ IS USED, OFTEN LOOSELY FOR BOTHPRAISE AND BLAME

RAMMOND MLLAMS KEMMORDS A VOCABULAAY OF

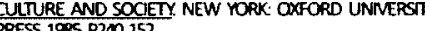

Fitter, happier, more productive

Comfortable

Not drinking too much

At ease

Eating well

(no more microwave dinners and saturated fats)

A patient better driver

Sleeping well (no bad dreams)

No paranoia

Careful to all animals

Keep in contact with old friends

(enjoy a drink now and then)

Favours for favours

No longer afraid of the dark or midday shadows

Nothing ridiculously teenage and desperate

At better pace

Slower and more calculated

No chance of escape

An empowered and informed member of society

(pragmatism not idealism)

Less chance of illness

A good memory

Still cries at a good film

No longer empty and frantic

(an ability to laugh at weakness)

Calm

Fitter, happier, and more productive 


\section{PROPOSITION}

\section{NORM・ODERN BUILDING}

Can a house improve our physical and psychological health ...?

Can a house provide the space for:

a) the young to learn from their own actions affected by the surrounding $\bullet$

b) the elderly to feel comfortable and convenient

c) the middle-aged (norm) to be fit and productive

d) all to be happy...?
COMFORTABLE:

CONFORTARE IATIN: TO

STRENGTHEN OR CONSOLE.

IN 1GTH CENTURY, THE WORD CAME TO MEAN TOLERABLE OR SUFFICIENT, AMPLE BUTNOT LUXURIOUS, ANDEVENTUALYYIT ACQUIRD TS SENSE OF PHYSICAL WELLBEING AND ENOYMENT IN THE 18TH

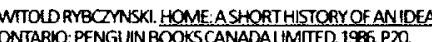

\section{NORM:}

NORMA LATIN:

CARPENTER'S SQUARE, RULE, PATTERN

1) RULE OR STANDARD OF BEHAVIOUR SHARED BY MEMBERSOFA SOCIALGROUP TOWHCH ECHMEMBER SEXPECTEDTO CONFORM; NORMS ARE MORE SPECIFIC IS A VALUES OR IDEALS-HONEST IS A GENERAL VALUE, BUT THE RULES IN APARTICUIAR SITUATIS BEHAUT

II) ANOTHER NAME FOR MODE.

NORM. ENCYCLOPEOIA BRITANNICA, INC.

\section{- STAIRS WITH NO RAILING}

NO RAILNG DOES NOT MEAN THAT ONE WILL FALL, BUT IT NOT TO FALLATYOUNG AGE

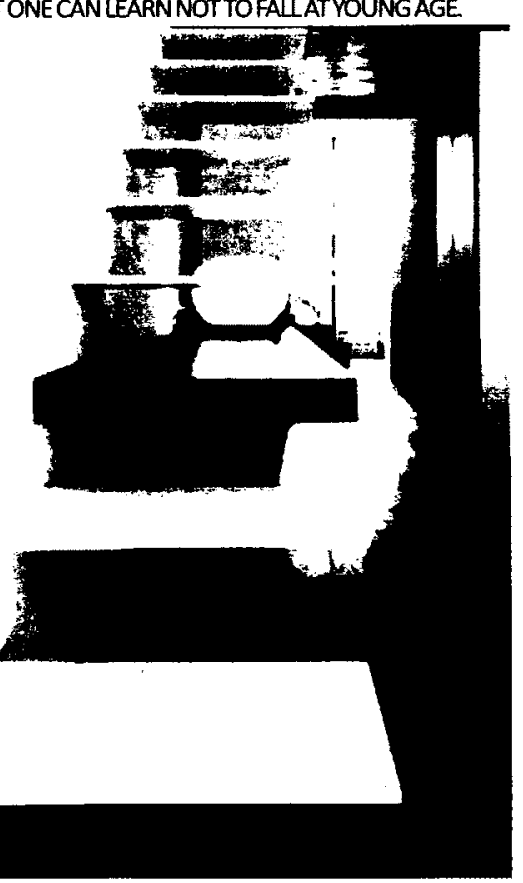


- THE WORD MODERN IN TTS LATIN FORM MODERNUS WAS USED FOR THE FIRST TIME IN THE LATE $5^{\text {TH }}$ CENTURY IN ORDER TO DISTINGUISH THE PRESENT FROM THE ROMAN PAST

MODERNITY REVOLTS AGAINST THE NORMALIING FUNCTONS OF TRADIION MODERNIT LVES ON THE EXPERIENC OF REBEWNG AGANST All THAT IS NORMATIVE. THIS REVOLT IS ONE WAY TO NEUTRALZE THE STANDARDS OF BOTH MORALTYANDUTUTY.

JURGEN HABERMAS. 'MODERNITY: AN IN COMPLETE PROIEC HA W WES MON CRMDU AN IN COMPETE ANT-AESTHETC: ESSAYS ON POSTMODERN CUITUR

- IN THE FIRST MANIFESTO OF DE STJL 1918 THEREISANOLDANDNEWCONSCIOUSNESS OFTHEAGE. THEOLDISDIRECTED TOWARDS THE INDIVDUUAL, AND THE NEW TOWARD THE UNIVESAL THE NEW ART HAD REVEALED THE SUBSTANCE OF THE NEW CONSCOOUSNESS OF THE AGE: AN EQUAL BALANCE BETWEEN THE UNIVERSAL AND THEINDMDUAL

THE ELEVENTH POINT OF VAN DOESBURGS 16 POINTS OF A PLASTIC ARCHITECTUR READS: THE NEW ARCHTECTURE IS ANT CUBIC, WHICH DOES NOT TRY TO FREEZF THEDIFFERENT UUNCTONALSPACECELSIN ONECOSEDCUBE RATHER, TT THROWSTHE FUNCTIONAL SPACE CELUS CENIRIFUGALLY FROM THE CORE OF THE CUBE AND THROUGH THIS MEANS, HEIGHT, WIDTH, DEPTH, AND TIME APPROACHES A TOTALIY NEW PLASTCEXPRESSION INOPEN SPACES IN THIS WAY ARCHTECTURE ACQUURES A MORE OR LESS FLOATNG ASPECT THAT WORKS AGAINST THE GRAVITATIONAL FORCESOFNATURE. KENNETH FRAMPTON. MOOERN ARCHIECTURE: A
CRMTCAL HISTORY LONOON: THAMES \& HUDSON LDD. 1992
P145.

1 KENNETH FRAMPTON. MODERN ARCHITECTURE: A
CRTIICAL HISTORY IONDON: THAMES \& HUDSONITD
Being modern, encouraged by exponential acceleration of technology, implies universal standardization of scale/dimensions of development/ product, and our aesthetic taste in it (what is up-to-date/outdated, rather than what is good/not good).

There has continuously been the paradox and struggle in taking part in modern civilization. "On one hand the nation has to root itself in the soil of its past, forge a national spirit and unfurl this spiritual and cultural revindication," and on the other hand keeping up with the universal movement toward the 'very present' and 'more present'. 


\section{OBSERVATION}

HOUSING DEVELOPMENT:

VERTICAL / HORIZONTAL

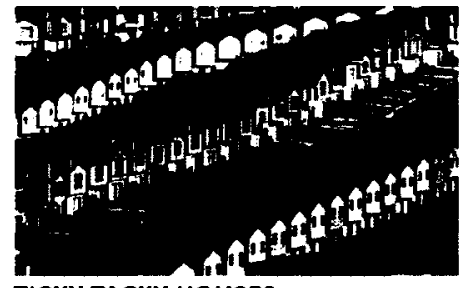

TICKY TACKY HOUSES.

LEVITTOWN, NY. 1950'S

THEHOUSINGSHORTAGEFOLLOWINGTHE END OF WWII FORCED DEVELOPERS TO ADOPT MASS PRODUCTION TECHNIQUES TO MEET DEMAND. REPETITIVE HOUSING CONSTRUCTON METHODS TRANSLATED INTOTHEBUILDINGOF3OHOUSESADAYIN LEVITTOWN. ANDWITH MASS PRODUCED HOUSES CAME A REPETITION THAT IS GLARING IN ITS DEHUMANIZATION.

DEPARTMENT OF REPETIION DEPARTMENT "REPETITON AS CONFOFMITY PART 1". HTTP/TMEDROWORDPRESS
COM.ACCESSEDONDEC21,2012.

\section{PLACE:}

TIME AND SPACE TOGETHER INHABITED AND PERCEIVED WHICH ONE CAN REVISIT ANO REMEMBER. (OEFINED BY AUTHOR)
In the past half century in North America we see largely two types of housingdevelopmenttoaccommodate populationgrowth and accelerated speed/span of transportation: either by horizontal expansion or by vertical stretch. The horizontal: in the suburbs where the neighbours are laid out like Domino; the vertical: in the high-rise condos where the neighbours are stacked up like Jenga (efficiency). In either case the residents are strangers to each other, strangers who share common dimensions of living box but share no communications. Development used to be Scrabble, where residents build as they live, by making the best of available space and resources (productivity). And development became Crossword Puzzle, where perfectly planned patterns are laid by the key players and planners; patterns were formulated around common places. (Refer to the following page for the visual.) And today, we seem to only find personal/social time and space commonly in the virtual world, that we merely inhabit time or space. Caught in the fast paced, hypersensory system, one can easily lose the sight, boundary and control of one's personal space. Under such circumstances, how can one re-situate oneself in a common place (community) and regain consciousness for basic yet original senses (personal space)? 


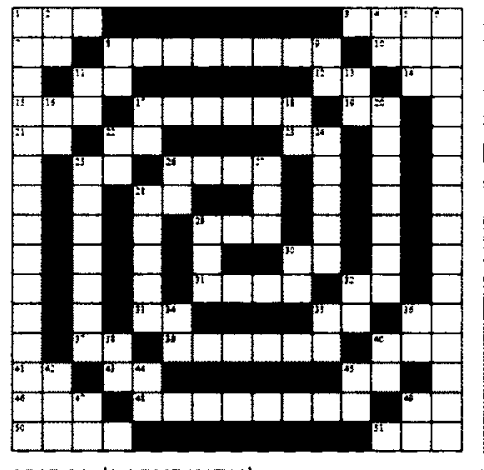

SPIRAL (LABYRINTH)

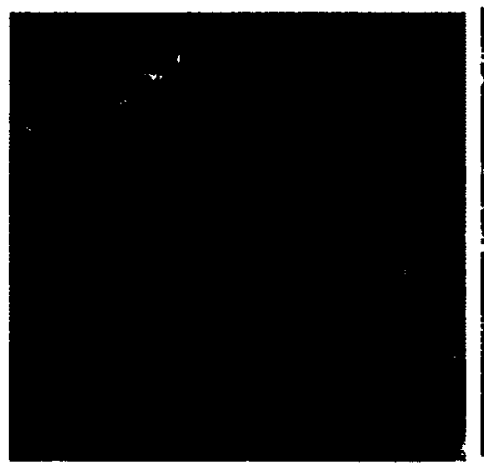

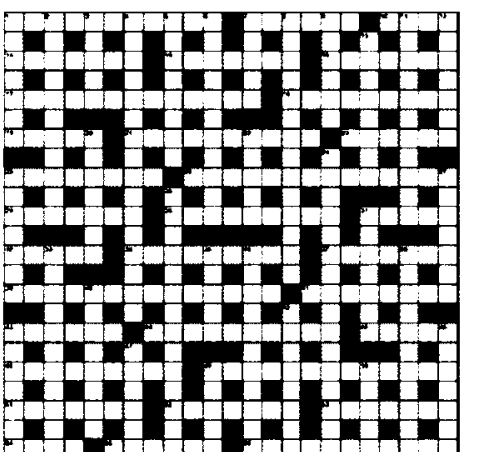
DENSITY (TOKYO)

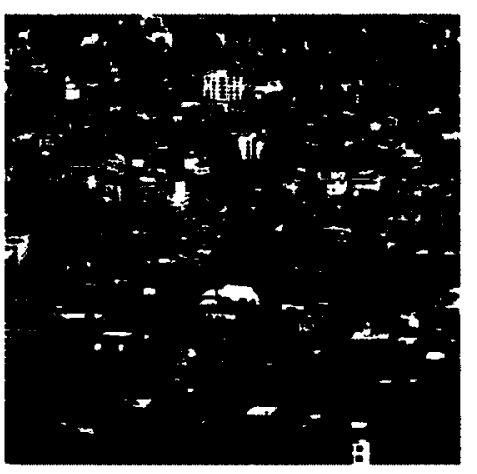

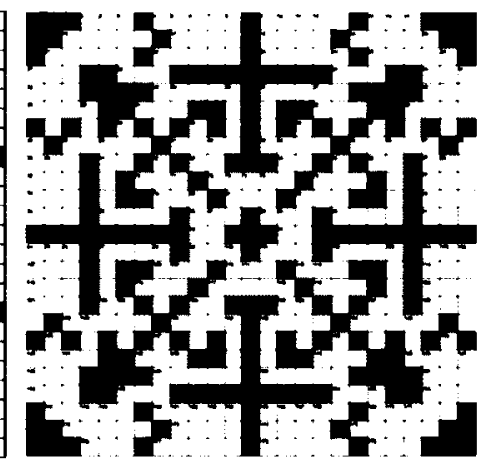

CENTRIPETAL (PARIS)

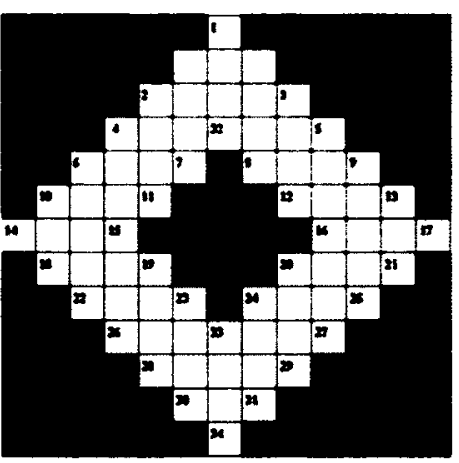

QUADRATIC (CALGARY)

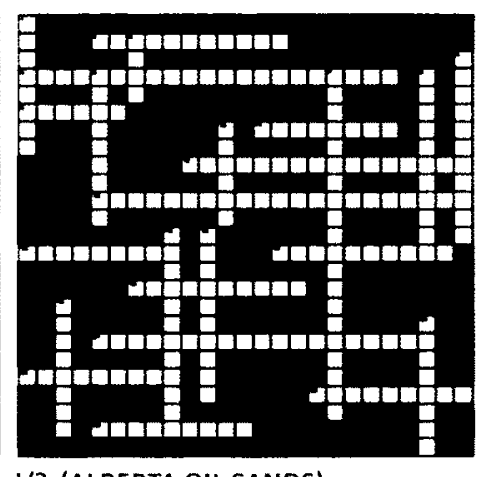

1/? (ALBERTA OIL SANDS)
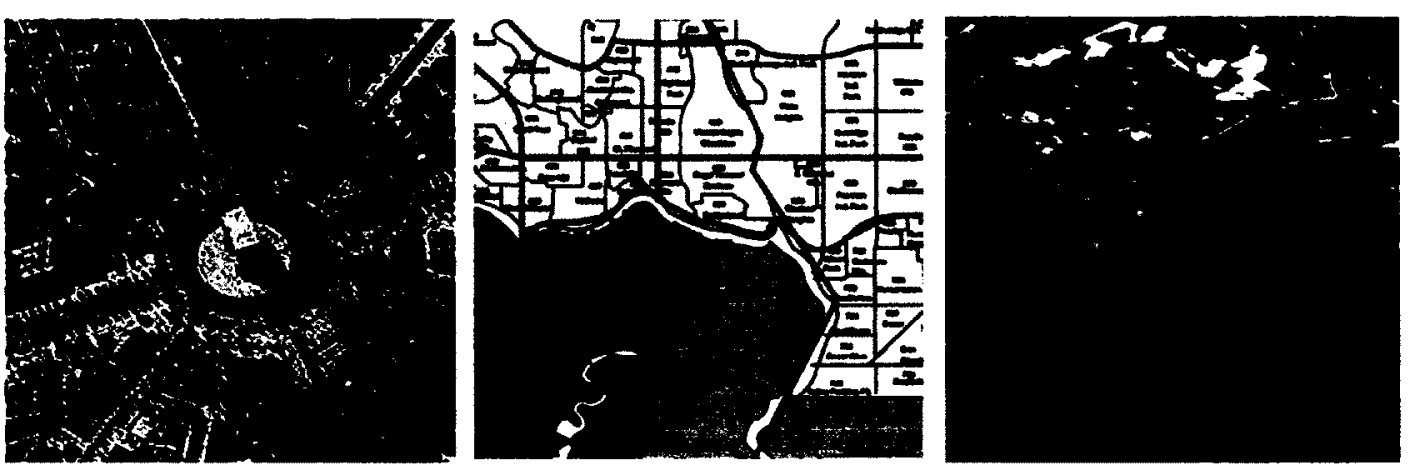

- pattern language

CROSSWORD PUZZLE DEVELOPMENT, WHERE PERFECTLY PLANNED PATTERNS ARE LAID BY THE KEY PLAYERS AND PLANNERS; PATTERNS WERE FORMULATED AROUND COMMON PLACES 
PRODUCTIVITY:

DVERALL PERFORMANCE OF AN ACTION AND ITS CONSEQUENCES IN REFLECTION OF THE ORIGINAL INTENTANDPURPOSE. QUALITATIVE FFECTS, (DEFINED BY AUTHOR)

\section{EFFICIENCY:}

ACHIEVEMENT OF QUANTITATIVE DISPLACEMENT OVER A SEGMENT STATISTICS. (OTIONE INDEPENDET

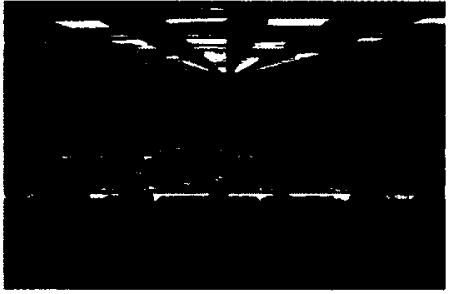

MANUFACTURED LANDSCAPES. 2006. AS OPPOSED TO CRAFT, IT CONTAINS NO REAL RECORD OF THE HUMAN IN ITS MAKING.

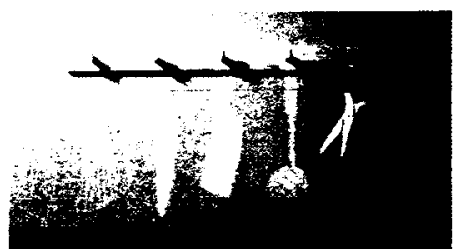

OSAI THAI INSTANT FOOD AD. 1998. THERE IS A GAP BETWEEN A FUNCTION AVALABLE TO EVERYONE AND KNOWN TO VIRTUALYY NO ONE.
Differentiating productivity/efficiency can yield the most fitted balance of positive/negative use of resources. Knowing where, when and how to be efficient and productive can improve quality of performance, from everyday details to social networking to large scale space making

Machine-run systems and technological innovations were to assure efficiency in a particular segment of a production line, although productivity would be a measure demonstrating a balanced performance of the consequences and embodied energy of the entire production line:

In the 1970s new technological arrangements were introduced: electronic breakthroughs. Precise automation and robotics have become a reality and have concentrated on quickness, agility and endurance." "As opposed to craft, technology contains no real record of the human effort and aspirations involved in its making. $\bullet$ In our day to day relationships with technology and technical devices we seldom understand how they work, how to repair them, let alone their histories or where they come from. Contrary to other human pursuits, there is a gap between a function available to everyone and underlying rules or machinery known to virtually no one."
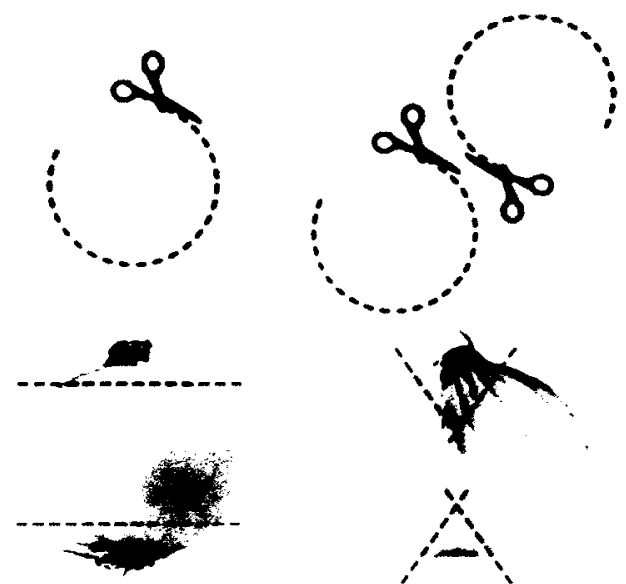

-EFFICIENCY / PRODUCTIVITY COMPARISON

SECTION TYPE A:

MAYBEMACHINEPRODUCED

AT HIGH RATE BUT YIELDS

LEFT-OVERS AND WASTES

SECTION TYPE B:

MAY REQUIRE SLOW PLANNING PROCESSES PLANNING PROCESSES BUT REDUCES TO THE MAXIMUMOUTCOME 


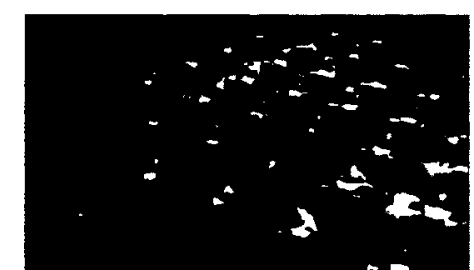

THE TRIAL. 1962. OFFICE SCENE. WHILE THE SOCIAL SCIENCE OF MANAGEMENT CAN CERTAINLY BE PRACTICED, THERE IS ALWAYS A DEGREE OF SOCIAL ANONYMITY AND IN THE END AMOUNTS TO A KIND OF IGNORANCE.
Not only we are able to cover greater distances in less time, in which we can be somewhere without moving the body, now things just happen around us without having to make them happen, or think about them before they happen, or feel what has happened. Sensory signals jump right in to the brain without really passing through the touch of bodies (of oneself and of the other). "With information processing and media, which have also resulted in an increased span of space in compressed time, globalization has come familiarity, and familiarity has come a lessening of distinctions between one place and another. Consequently, a sense of place, that the way by which we differentiate space in our minds and through our cultural activities, has become diminished."3

Now that we have tasted (or we think we have tasted) the greater boundaries of the world, we want to push it further and higher. Whether it is traveling, organizing daily agenda, or building new, bigger and more boxes to occupy, we compete amongst ourselves to achieve the top record. ${ }^{\bullet}$
THE URBAN MELTING POT PROMISES LITTLE MORE SIGNIFICANCE THAN MERE GIGANTISM, AGGRESSIVE UPWARD THRUSTING SKYSCRAPERS AND FLASHING NEON LIGHTS THE SKYSCRAPER, BORN OF LAND THE THE ELEVATOR, IS ALL TOO OFTEN YET IN CRITICAL SUPPLY OR WHEN FUNCTIN IS NOT IMPROVED BY VERTICAL ORGANIZATION.

CHERMAYEFF P56-57.

\footnotetext{
1 PETER G. ROWE, MODERNITY AND HOUSING.
CAMBRIDGE:MIT PRESS, 1995. P13.

2 IBID. P17-18.

3 1810. P22.

4 IBID. P3.
}

WHERE DO THE CHILDREN PLAY? CAT STEVENS.

WELLITHINK IT'S FINE,

BUILDING JUMBO PLANES.

OR TAKING A RIDE ON A COSMIC TRAIN. SWITCHON SUMMER

FROM A SLOT MACHINE.

GET WHAT YOU WANT TO IF YOU WANT 'CAUSE YOU CAN GET ANVTHING

WELL YOU ROLL ON ROADS OVER FRESH GREEN GRASS FOR YOUR LORRY LOADS

AND YOU MAKE THEM LONG

AND YOU MAKE THEM LONG,

AND YOU MAKE THEM TOUGH.

AND IT SEEMS YOU CANT GET OFF.

WHEN YOU CRACK THE SKY,

SCRAPERS FILL THE AIR.

WILL YOU KEEP ON BUILOING HIGHER

TIL THERE'S NOMORE ROOM UP THERE?

WILL YOU MAKE US LAUGH,

WILL YOU MAKE US CRY?

WILL YOU TELL US WHEN TOLIVE

WILL YOU TELL US WHEN TOLIVE,

I KNOW WE'VE COMEA LONG WAY, WE'RE CHANGING DAY TO DAY

DE CME

WHERE DO THE CHILDREN PLAY? 
Here rises the issue of widely defining a normative building program for appropriate accommodations, of designing for everyone but for no one in particular-the issue of standardization in design. ${ }^{4}$ This issue can be challenged by critically diagnosing regional specific features with bottomup or inside-out design approach. The financial input to such face-toface planning method can cost more than standardized planning and may seem not as efficient in construction at the time, but in the long run, the building and dwelling performance in all aspects, environmentally, socially, and politically, would have a healthy and productive outcome.

(To Scene 5. Construction: Critical regionalism)

VERTICAL/HORIZONTAL HOUSING PLANNING
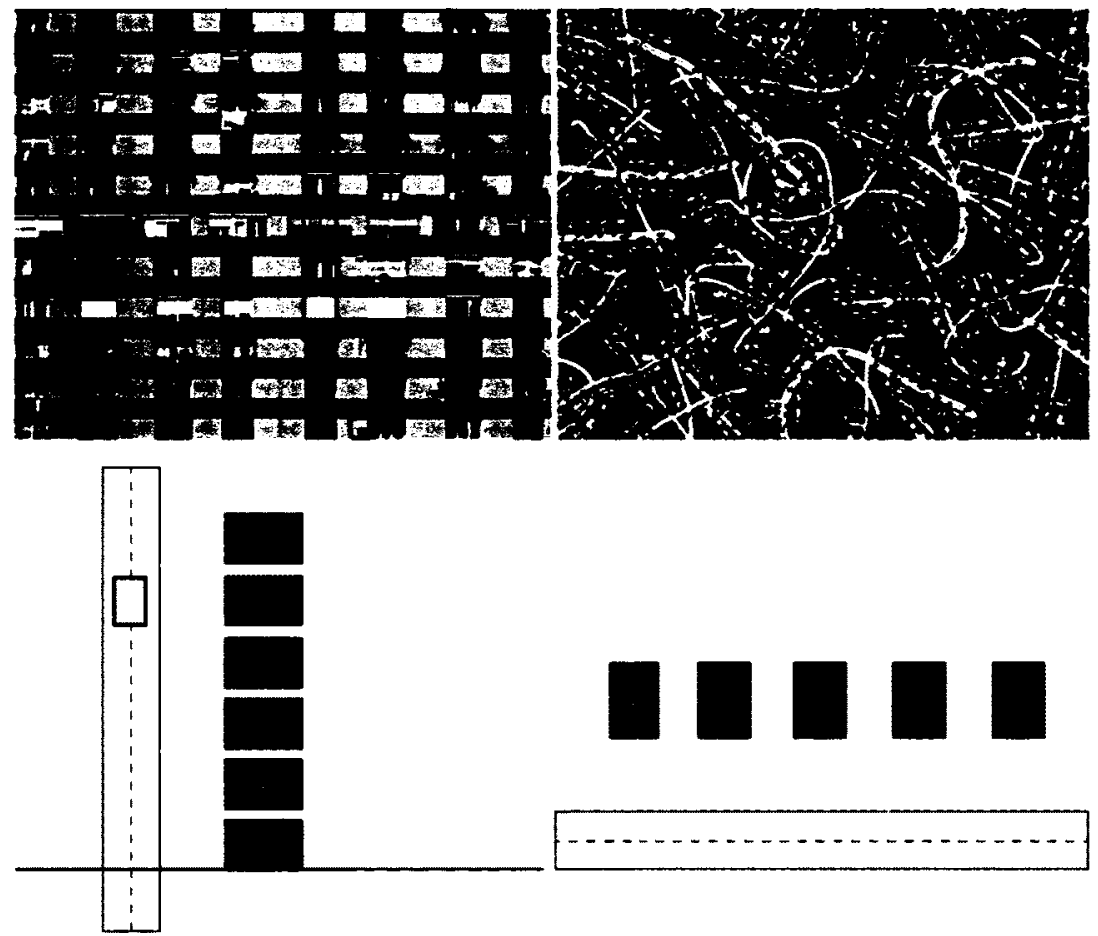

VERTICAL

TECHNOLOGY ALLOWS STRENGTH IN HEIGHT

OF A SINGLE BUILDING IN DENSE AREAS

HORIZONTAL

AMOUNT OF UN(DER)-DEVELOPED LAND ALLOWS WIDE-SPREAD OF COOKIE CUTTER HOUSES 
MAPPING I

VERTICAL/HORIZONTAL DEVELOPMENT

ELABORATION ON PATTERN LANGUAGE, SHOWING ONE EXAMPLE OF A SET OF PATHS EXPANDING IN THE VERTICAL AND HORIZONIAL DIRECTIONS FROM A TYPICAL SINGLE UNIT OF URBAN GRID

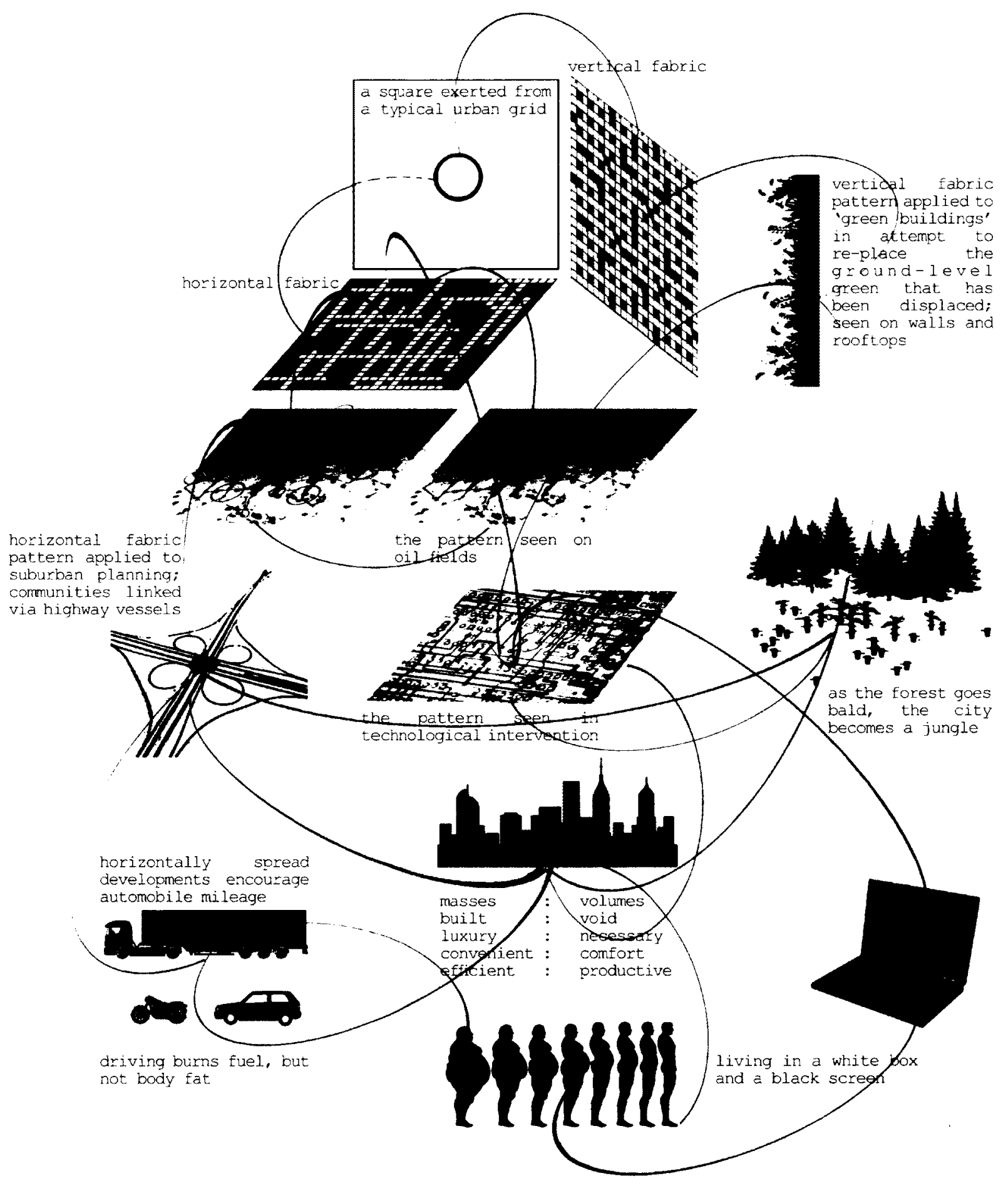


MAPPING ॥

VERTICAL:

[ IPE JPLACEMENT [DIS PIACEMENT [MIS] PLACEMENT
[MIS]PLACEMENT

TAKE ALBERTA AS AN EXAMPLE OF HOW AND WITH WHAT DIFFERENT PARTS OF LAND ARE PLACED-OR MAPPED. THE UNDERDEVELOPED LAND IS EXPLOITED TO DISPLACE WOOD UNTO THE DEVELOPED LAND FOR NEW UNTO THE DEVELOPED LAND EOR NEW CONSUCT WOOD FOR NEWER CONSTRUCTIONS TO ACCOMMODATE LACK OF PLACES IN THE URBAN AREA THE LOST GREEN IS REPLACED BY ARTIFICIAL PLANTING IN THE VERTICAL DIRECTION AS A COMPROMISE. THE URBANIZED AREAS RUN ONOISE. THE URBANIZED AREAS RUNO THE ENERGY SOURCE.

KENNETH FRAMPTON ARGUES WITH ONE OF HIS SIX POINTS FOR AN ARCHITECTURE OF RESISTANCE THAT MODERN BUILDING IS NOW SO UNIVERSALLY CONDITIONED BY OPTIMIZED TECHNOLOGY THAT THE POSSIBILITY OF CREATING SIGNIFICANT URBAN FORM HAS BECOME EXTREMELY LIMITED. THE RESTRICTIONS JOINTLY IMPOSED BY AUTOMOTIVE DISTRIBUTION AND THE VOLATILE PLAY OF LAND SPECULATION SERVE TO LIMIT THE SCOPE OF URBAN DESIGN TO SUCH A DEGREE THAT ANY INTERVENTON TENDS TO BE REDUCED EITHER TO THE MANIPULATION OF ELEMENTS PREOETERMINED BY THE IMPERATIVES OF PRODUCTION, OR TOA KIND OF SUPERFICIAL MASKING WHICH MODERN DEVELOPMENT REQUIRES FOR THE FACILITATON OF MARKETING AND THE MAINTENANCE OF SOCIAL CONTROL. TODAY THE PRACTICE OF ARCHITECTURE SEEMS TO BE ON THE ONE HAND, A SO-CALED ON THE ONE HAND, A SO-CALLED TXCLUCH APPONACH OREDICATED ON THE OTHER THE PROVISION OF A 'COMPENSATORY FACADE' TO COVAR COMPENSATORY FAÇADE TO COVER UNIVERSAL SYSTEM.

KENNETH FRAMPTON. 'TOWARDS A CRITICAL ON POSTMODERN CULTURE. ED. FOSTER. H. NEW

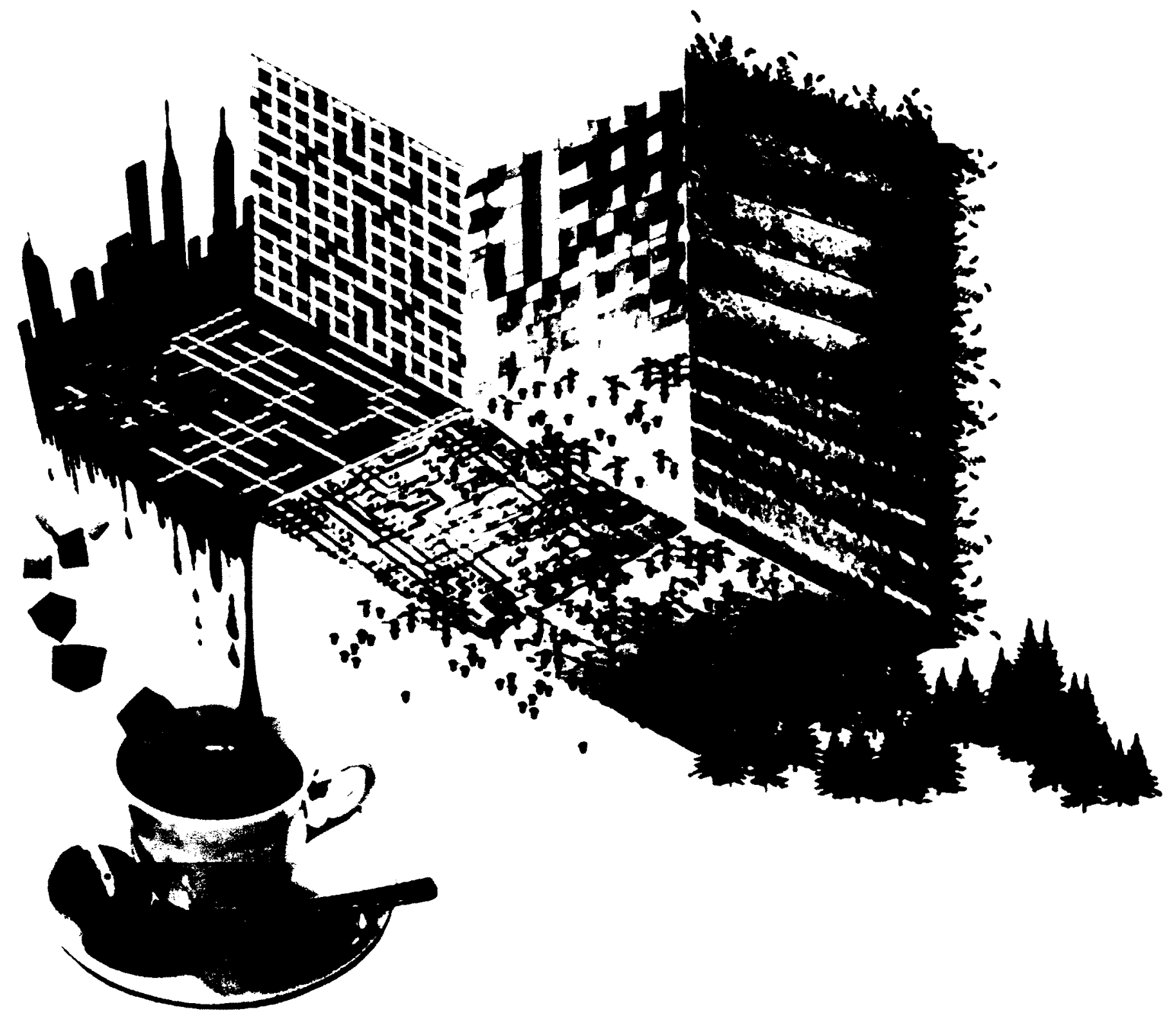




\section{DEDUCTION}

\section{PRE (- - )-FAB \\ PRE(TTY)-FAST \\ PRE(TTY)-FAT}

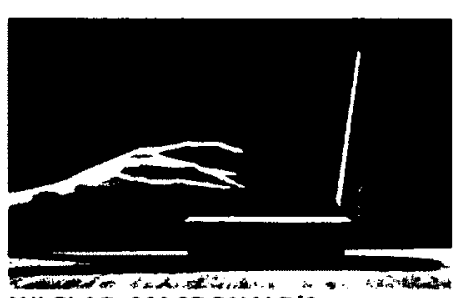

WI-FI AD, MACDONALD'S. FASTFOOD, FAST COMMUNICATION.ZERO DISPLACEMENT.

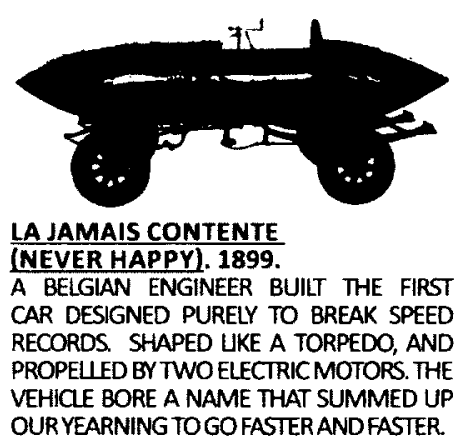

SERGE CHERMAYEFF AND CHRHSTOPHER ALEXANOER COMMMUNTYY AND PRINACY. TOWARD A NEW 1965 . Pro
Pre-fab, pre(tty)-fast, pre(tty)-fat! It is not the birthday cakes that make us fat, but the fast paced society expects the body to eat without cooking and transport without moving. Everything is made ready for us to consume in no time and in a large quantity, and we consume more than we work out. And to keep up or to catch up with the societal demands, we want more things and want them fast. The more we try to improve on efficiency, the less we achieve in productivity.

Overstimulation at the high, loud, fast end of the spectrum of experience, and deprivation at the low, quiet, slow end is robbing man of balanced variety. Attention is focused largely on the conspicuous dramatic inessentials: the new records, the fastest race, the highest building, the brightest lights, the biggest audience, the largest fortune. The apparent increase in variety in our wealthy, industrialized society may turn out to be a new form of monotony of mass-produced commodities. More and more becomes less and less, and mere quantity and repetition of individually stimulating events kills their effectiveness. ${ }^{1}$ 


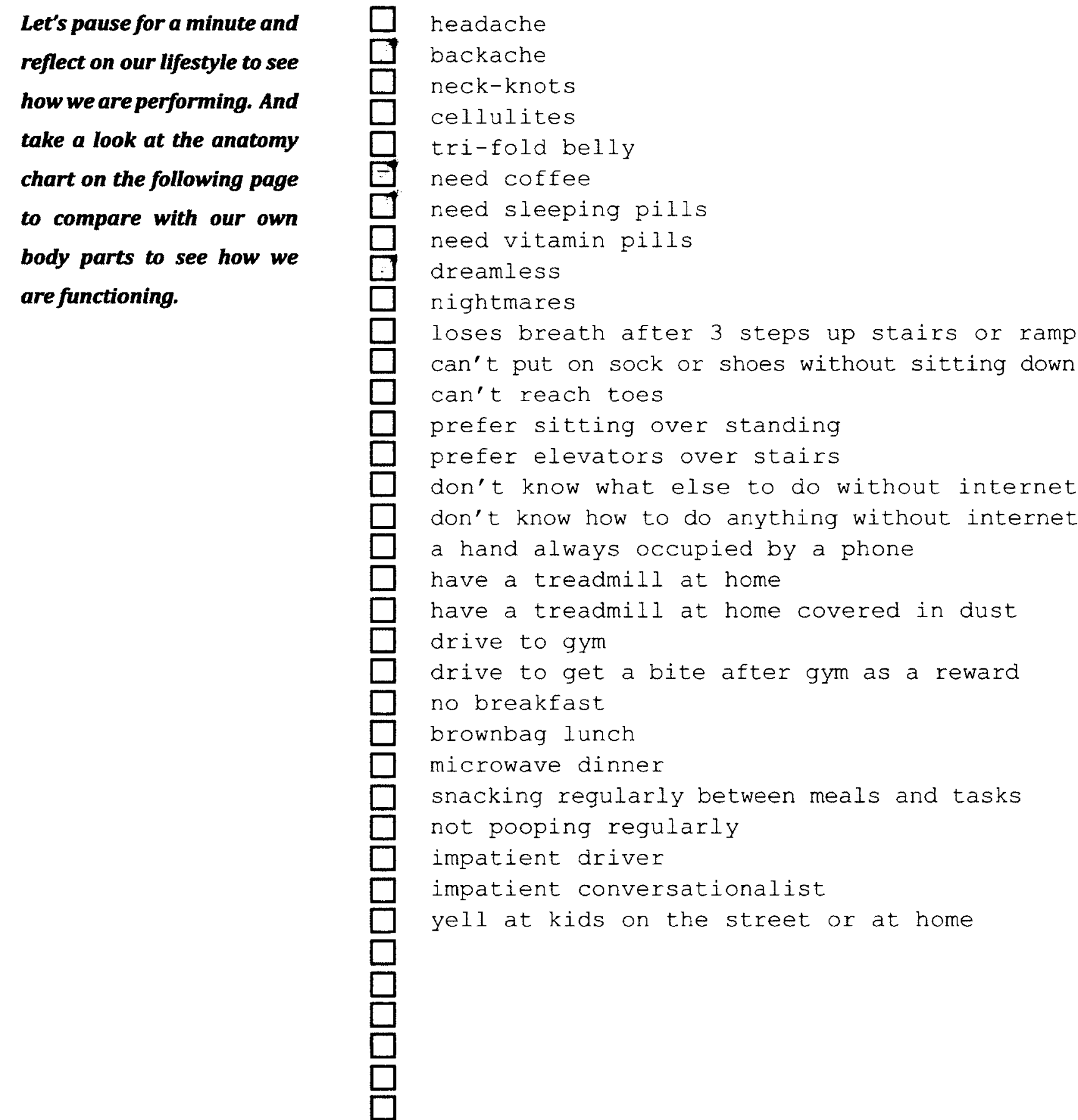

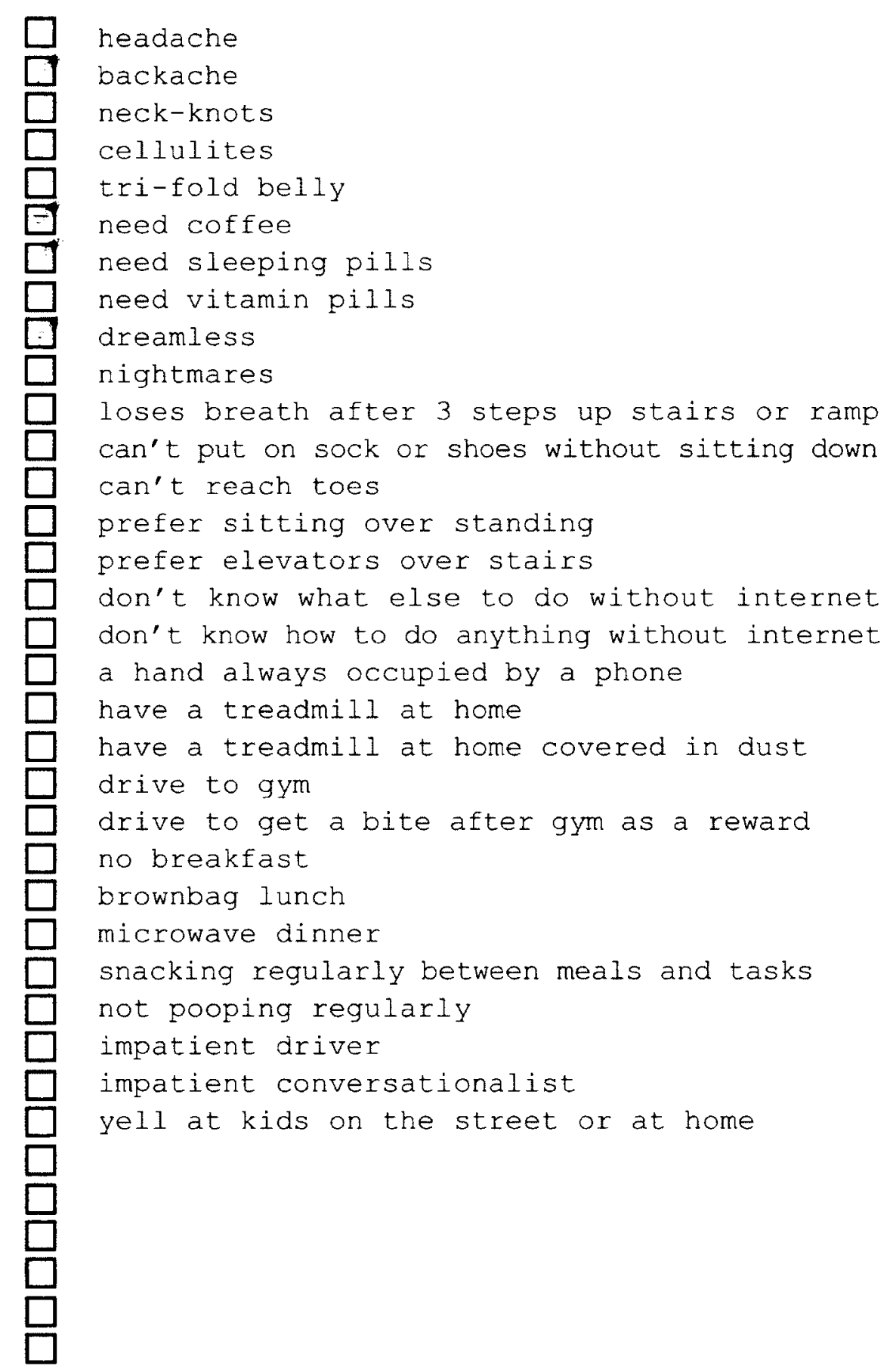

SYMPTOMS OF LIVING IN A FAST WORLD DO A SELF-CHECK-UP. FILLIN THE BOX, FILL IN THE BLANK. IF FULLY FILLED, YOU ARE IN TROUBLE. 


\section{CLASSICAL ANATOMY}

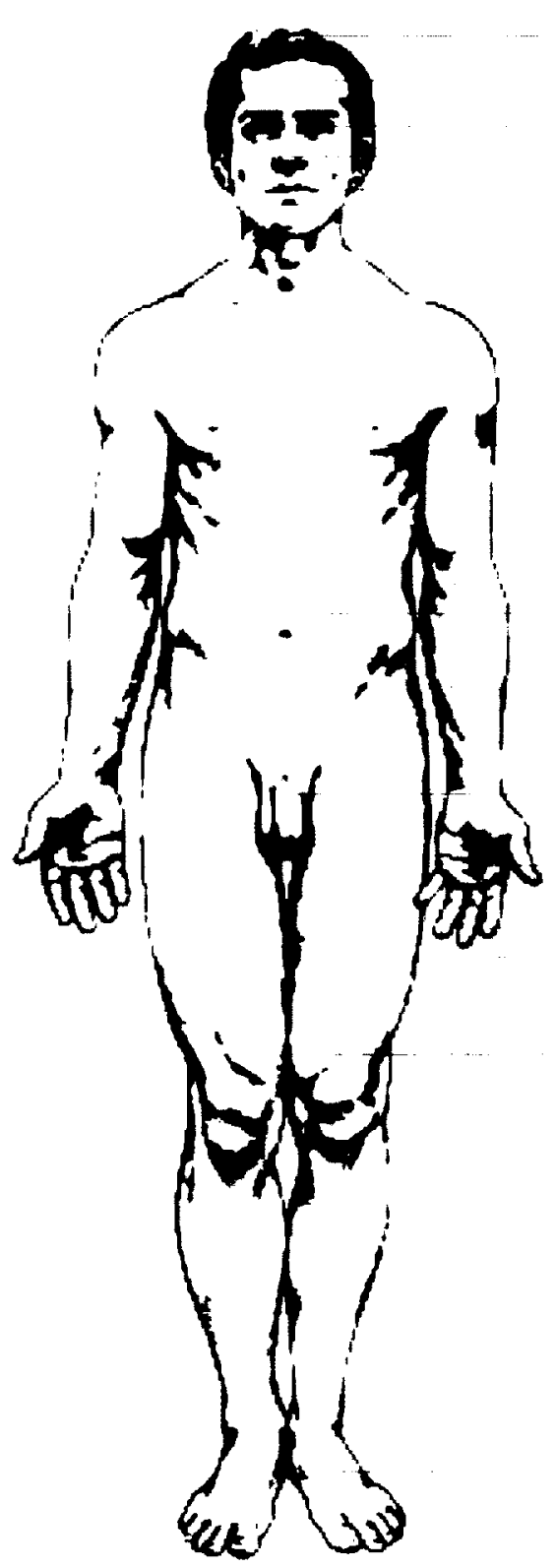

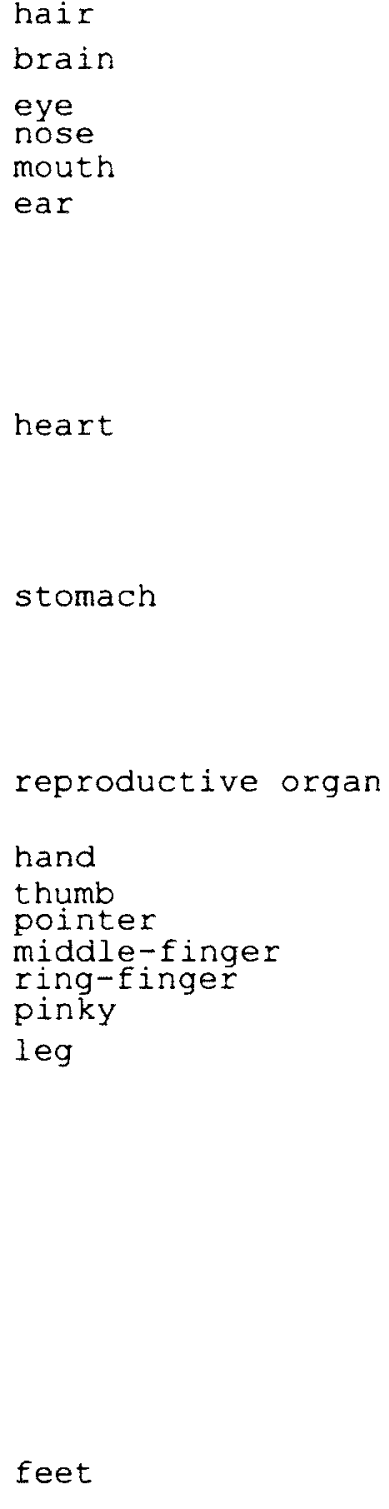

MODERN ANATOMY

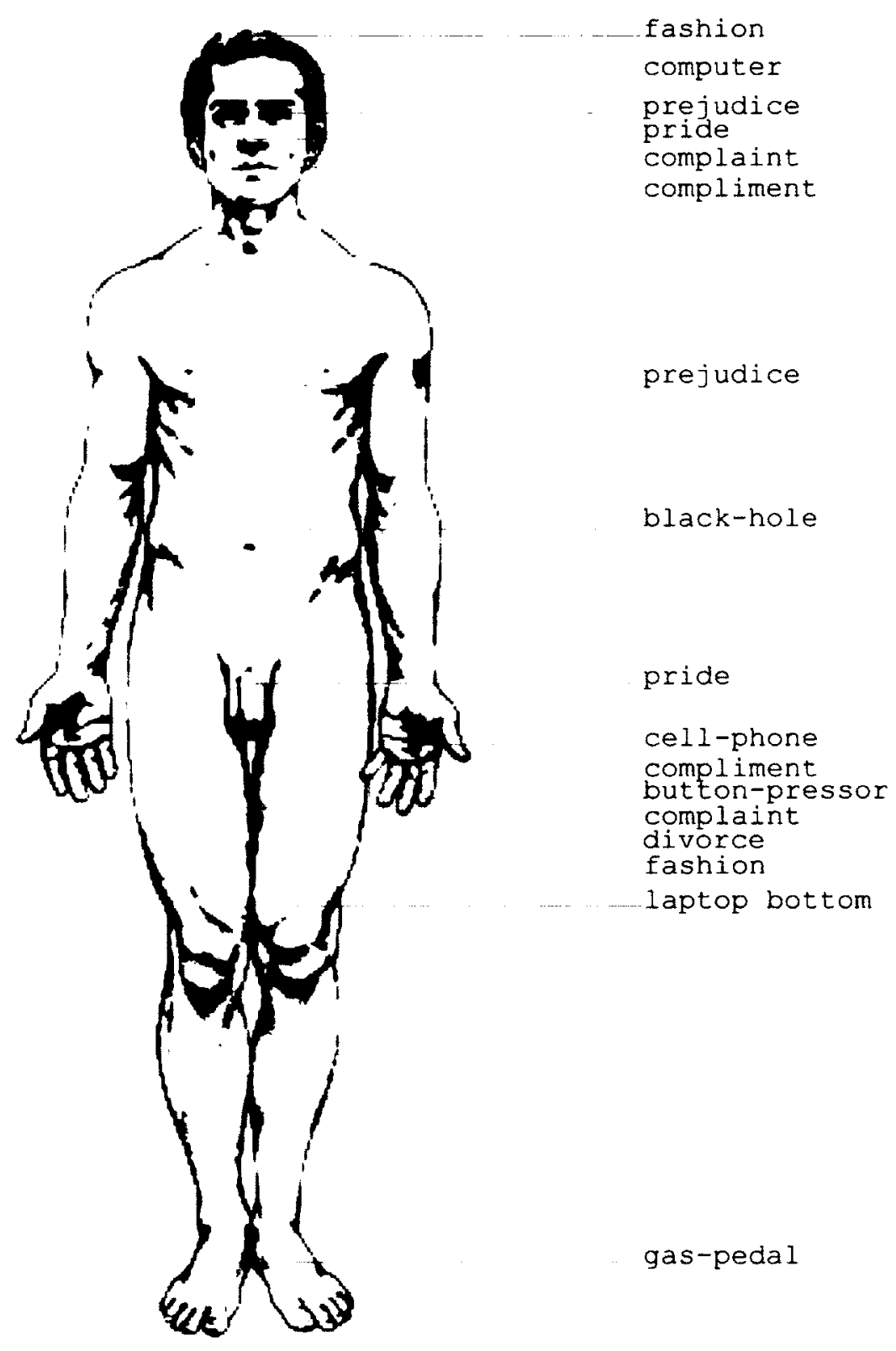




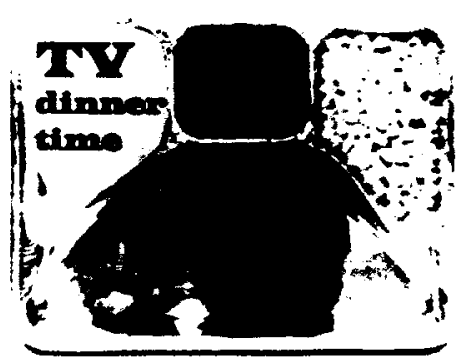

TV DINNER

"GOBBLE, GULP AND GO FAST FOOD FILLS YOU UP WITHOUT SUSTAINING YOU.
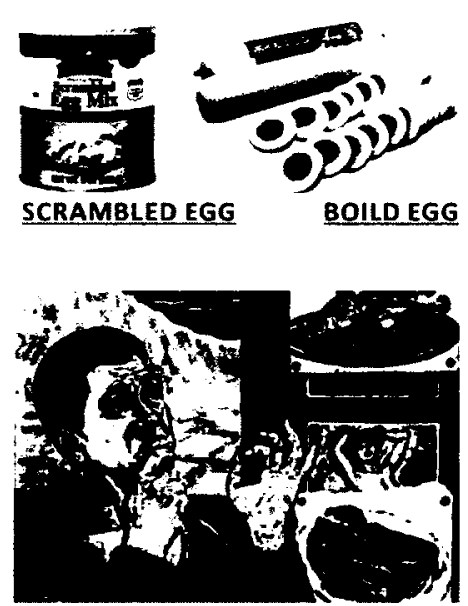

MEAL INA PILL

- in the PURSUIt OF LOW COSTS AND HIGH PROFIT, INDUSTRIAL FARMS DO DAMAGES TO LIVESTOCK, THE ENVIRONMENT AND THE CONSUMER. INTENSIVE AGRICULTURE IS NOW A LEADING CAUSE OF WATER POLLUTION IN MOST WESTERN COUNTRIES. IN 2003, RESEARCHERS CALCULATED THAT BRITISH TAXPAYERS SPEND UP TO 2.3 BILLION POUNDS EVERY YEAR REPAIRING THE DAMAGES THAT INDUSTRIAL FARMING DOES TO THE ENVIRONMENT AND HUMAN HEALTH. (NOW THINK ABOUT WHAT IS AN APPARENTYY EFFICIENT METHOD MAY NOT NECESSARILY YIELD PRODUCTIVE CONSEQUENCES.) CARL HONORE. IN PRAISE OF SLOWNESS. TORONTO
"We are moving from a world in which the big eat the small to one in which the fast eat the slow. That warning resonates far beyond the Darwinian world of commerce. We have developed an inner psychology of speed, of saving time and maximizing efficiency. Evolution works on the principle of survival of the fittest, not the fastest. ${ }^{\bullet}$ (It is no coincidence that the fastest nations are also often the fattest.)"1

The human cost of capitalism is the mental and psychological input/ output. The economy may make us materialistically wealthy (which in fact only applies to a small crowd on top of the food chain), but it also gives us an illusion that we can only be materialistically happy.

At the peak of the industrial century, Benjamin Franklin paired the two entities: input and output, pace and profit, "by an aphorism: Time is money. Workers were paid by the hour instead of for what they produced" ${ }^{2}$ or how they worked.
- SURVIVAL OF THE FITTEST CHARLES DARWIN. ORIGIN OF SPECIES. 1869.

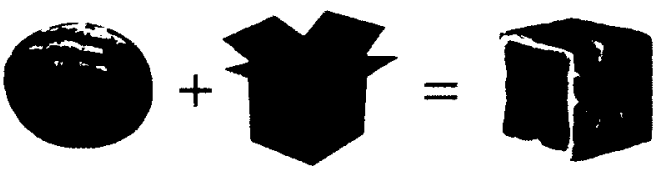

FITTER, HAPPIER, MORE PRODUCTIVE

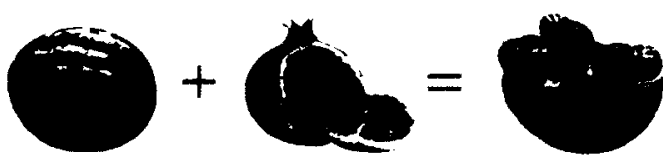


"Why, amid so much material wealth, is time-poverty so endemic?" Subconsciously, we have the biggest deadline of all, mortality, in the back of our head pressuring us to make something of every second in life. "But if the instinct to do so is universal, then why are some cultures more prone than others to race against the clock? In some philosophical traditions, time is cyclical. The Inuit use the same word uvatiarru to mean both 'in the distant past' and 'in the distant future'. Time in such cultures is always coming as well as going. It is constantly around us, renewing itself, like the air we breathe. In the western tradition, time is linear, and arrow flying remorselessly from $A$ to $B$. It is a finite, therefore a precious resource."3

The first thing we do when we wake up is check the time. The digital one with anxious noise alarming us, not the biological clock with heartbeats. Digital time makes the mind think that the body is incapable, but the body knows best what feels right and what is forced, it has its Natural Time, in sociologists' term. 
QUE NO SON TODOS LOS TIEMPOS UNOS. (NOT ALL TIMES ARE THE SAME) WE HAVE FORGOTIEN HOW TO LOOK FORWARD TO THINGS AND HOW TO FORWARD TO THINGS, AND HOW TO
ENJOY THE MOMENT WHENTHEY ARRIVE.

'EMPTY TIME IS NOT A VACUUM TO BE FILLED, IT IS THE THING THAT YOUR MIND TO BE CREATIVELY REARRANGED LIKE THE EMPTY SQUARE IN THE $4 X 4$ PUZZLE THAT MAKES IT POSSIBLE TO MOVE THE OTHER FIFTEEN PIECES AROUND IN OTHER WORDS, DOING NOTHING BEING SLOW, IS AN ESSENTIAL PART OF GOOD THINKING.

- HARRY LEWIS, HARVARD
We try to be efficient in the following ways: a) working on one thing for longer hours; b) working for one thing in shorter time; c) working on two or more things at once; d) working less on other things. These four have one thing in common: the purpose of getting things done. And this common purpose results in the same finishing line (or un-finishing line) of not getting any thing done well. Setting the bar high is a positive input, but we must find the fitted way to work toward it. "A life of haste can become superficial." When we work mechanically, we "fail to make real connections with the world or other people." ${ }^{\prime 4}$ To be productive, we must work hard as well as play hard, or take it easy as well as stay at ease. A balance of all things we want to do is the solution to untie the knots in the shoulders.

The fast moving mass does not only impact the grown-ups, but children suffer more without knowing it. Grown-ups try to raise children fast, without giving them a chance to discover the real whys and hows of things, like simply knowing where each breakfast item comes from. (Many in the younger generations have no idea eggs come in a shell, laid by hens.) Plato believes the most effective kind of education to a child is playing amongst lovely things, and for grown-ups, the highest form of leisure is to be still and receptive to the world. 
FAST:

BUSY, CONTROLLING, AGGRESSIVE, HURRIED, ANALYTICAL, STRESSED, SUPERFICIAL, IMPATIENT, ACTIVE, QUANTITY-OVER-QUALITY.

\section{FAST THINKING}

RATIONAL, LINEAR, LOGICAL DELIVERS CLEAR SOLUTIONS TO WELL-DEFINED PROBLEMS.

\section{SLOW:}

CALM, CAREFUL, RECEPTIVE, STILL, INTUITIVE, UNHURRIED, PATIENT, REFLECTIVE, QUALTYYOVER-QUANTITY

\section{SLOW THINKING:}

YIELDS RICH AND SUBTLE INSIGHTS.

WALKING TAKES LONGER THAN OTHER FORMS OF LOCOMOTION. THUS IT STRETCHES TIME AND PROLONGS LIFE. LIFE IS ALREADY TOO SHORT TO WASTE ON SPEED. WALKING MAKES THE WORLD MUCH BIGGER AND THEREFORE MORE INTERESTING. YOU HAVE TIME TO OBSERVE DETAILS

- EDWAEDABBEY,AMERICANENURONMENTAUST
Fast and slow describe ways of being, beyond measuring a rate of change. "Being slow means that we control the rhythm of our own life. Slow activists are not out to destroy the capitalist system. Rather, they seek to give it a human face."

Let the mind be still. As one Zen master put it: instead of saying don't just sit there and do something, we should say don't just do something, sit there. One must be slow on the inside to be fast on the outside. Franz Kafka as well agrees: 'You don't need to leave your room. Remain sitting at your table and listen. Don't even listen, simply wait. Don't even wait, be quiet still and solitary. The world will freely offer itself to you to be unmasked. It has no choice. It will roll in ecstasy at your feet.'

People who want to live better in a fast-paced, modern world seek to live at what musicians call the tempo giusto, the right speed.

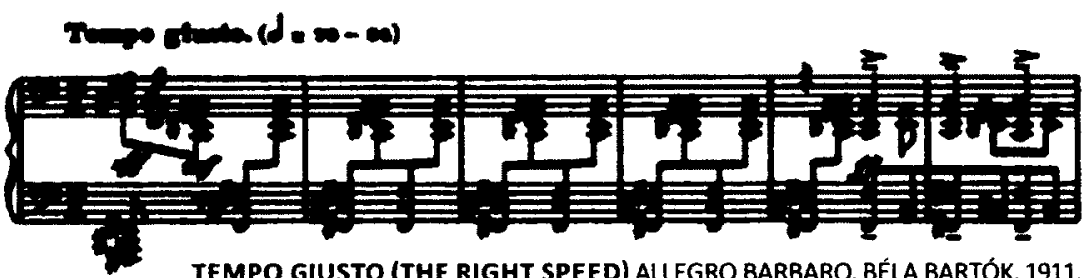

TEMPO GIUSTO (THE RIGHT SPEED) ALLEGRO BARBARO. BÉLA BARTÓK. 1911.

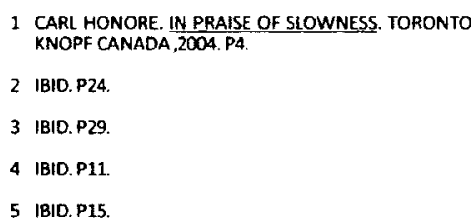


POSSIBLE 


\section{CON S T R U C T I O N \\ CRITICAL REGIONALISM}

What could be a slow solution in this proposed project? Critical Regionalism is an appropriate approach (although preferred not to be categorized under a movement, this term is the most fitted description.]

Critical Regionalism indicates an approach to design giving the priority to the identity of the particular rather than to universal dogmas (without the sentimental, prejudiced use of Regionalism); also the responsibility to define the origins and constrains of the tools of thinking that one uses, of which, the reason has to do with the ubiquitous conflict in all fields between globalization and international intervention, on the one hand, and local identity and the desire for ethnic insularity, on the other. ${ }^{1}$

Instead of building on a site, a fitter method of construction shall be building the site, as referred by Mario Botta, as an act of cultivation. ${ }^{2}$ 


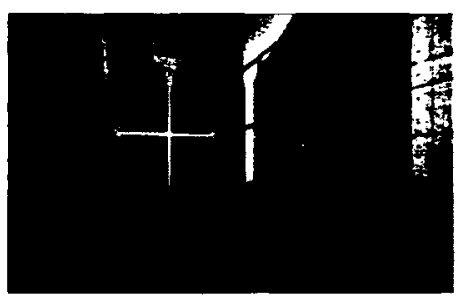

CHURCH OF LGGHT JAPAN. TADAO ANDO.

PRACTICE OF THE PHILOSOPHY OF WABI-SABI IS ATTAINED IN TADAO
ANDO'S WRITTEN AND BUILT ANDORKS WHERE'THE SIMPLEST AND MOST BASIC HUMAN ACTIVITIES ASSUME IN A POETIC RESONANCE. THE TERM WABI-SABI IS DERIVED FROM BUDDHIST TEACHING OF EXISTENCE: IMPERMANENCE, IMPERFECTION, AND ABSENCE OF SELF. THE AESTHETIC OF THE CONCEPT DEPICTS ASYMMETRY ASPERITY, MODESTY, INTIMACY, APPRECIATION OF NATURE, AND SUBLIME REALM OF THE SELF AND OTHER

ALTHOUGH ANDO'S CRAFT OF ALNCRTE IS SEAMLESS AND ATE AHE RAW FINISH OF THE SURFACE WHERE UIGHT AND SHADOW CAST UPON UNDER AND BETWEEN TO EXPRESS ANDO'S WAY OF CARING FOR THE INSCRIBED VOLUME AND ITS INHABITANTS, BELIEVE THAT THE WAY PEOPLE LIVE CAN BE DIRECTED A LITTLE BY (BUILDING) SAYS ANDO 'AND PEOPLE ALWAYS RELATE TO THE SPIRIT OF THE PLACE OR TO THE SPIRIT OF THE TIME. WE CANNOT SIMPLY PUT SOMETHING NEW INTO A PLACE. WE HAVE TO ABSORB WHAT WE SEE AROUND US, WHAT EXISTS ON THE LAND AND USE THAT KNOWLEDGE ALONG WITH CONTEMPORARY THINKING TO INTERPRET WHAT WE SEE.

CATHERINE SLESSOR. CONCRETE REGIONALISM. ONDON: THAMES \& HUDSON, 2000

FOUNDATIONS-AMBUIA KNOWLEDGE INITTATIVE COM/PEOPLE/LEGENDS/TADAO-ANDO ACCESSED. MAR. 9, 2013.
Building the site led me to have a conversation with another self about a friendly construction method toward the social and geographical environment with a familiar face, skin, bones and flesh to the city fabric of Ottawa.

S2: So who is the subject of your project?

S1: The people.

S2: The people?

S1: Well, I guess not really the people. They are more like the actors and the audience of the play I am writing.

S2: Right. Then to whom is the message of your play directed?

S1: The system. And whoever drives it. It is too easy to say, but representatively the government.

S2: What is their problem?

S1: They may seem to be efficient at some things, but not productive in the right sense. For instance, they decide to beautify a main city highway by resurfacing the asphalt and putting on sculptural bicycle racks designed by an artist with high commission which can only hold one or two bicycles at a time, as opposed to planning safe paths for bicycles and pedestrians throughout the city to encourage healthier means of transportation and reduce the automobile usage. The stress is off the point. 


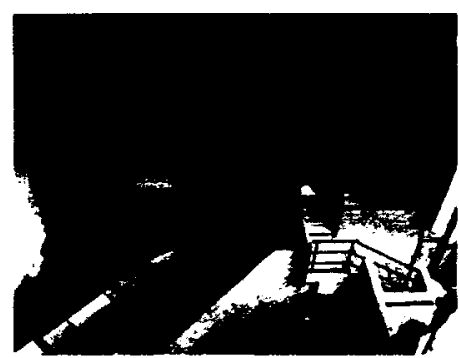

CASTELVECCHIO ITALY. CARLO SCARPA CAREFULLY CRAFTED DETAILS: WHERE THE MATERIALS MEET, HOW THEY MEE

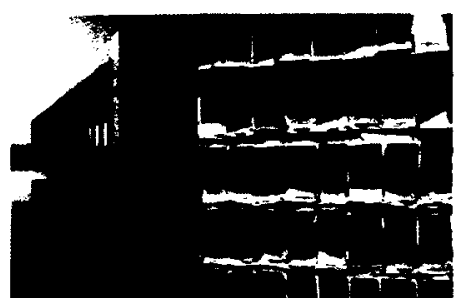

CERAMIC HOUSE, CHINA. WANG SHU. BRING OUR SENSE BACK TO THE TOUCH

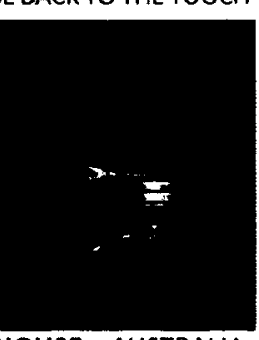

SIMPSON-LEE HOUSE, AUSTRALIA GLENN MURCUTI.

TOUGHEARTHUGHTIY ISTHEFOUNDATION

OF HOUSES THAT BREATHE IN PARALLEL

WITH NATURE. THE HOUSE CAPTURES

WND, UGHT, WATER AND FEEDS INTO THE FUNCTIONALSYSTEM
S2: Are you trying to change the system?

S1: No, but yes. Change is not made by force, but by awareness and effort. It will not happen fast, but eventually I hope the system will take it slowly but surely and use the energy on the right place and right time. Eventually, the input output energy should be in balance and in cycle from within the micro environment. For instance, an old lady must take the elevator to her 5 th floor apartment, she then in return contributes 3 pots of tomato plants to the community. Meanwhile a young man who uses the stairs to his 5 th floor apartment takes 3 tomatoes each week, he then in return mows the lawn of the lot on weekends. Meanwhile a family with children spends a lot of time on the freshly mowed lawn, and so in return they take a charge in collecting rainwater to water the lawn and plants and to flush the toilet. And so on and so forth.

S2: It sounds like communism or utopia.

S1: I think we can get closer to those ideas, by consciousness and by choice. And I don't think they are negative terms by their original sense and intentions. 
A building shall exist not as a mass on a site but as a volume which our body-does not occupy but instead-takes a part in inhabiting the site altogether. Windows are not just openings and walls are not just boundaries, but are eyes and skins through which we see and feel the colour of breeze, the smell of trees, the singing of birds, the tapping of rain......... A norm-odern building shall breathe with the site, transform with the seasons, and sense the touch of our body language. The building and our body shall be complementary in growth and decay, serving well, being served well, and aging well together. 


\section{INVITATION}

THE VISIT - STRANGERS TO OURSELVES

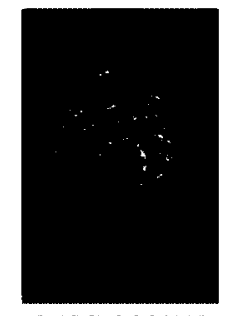
THE STRANGER, ALBERT CAMUS. ABSURDITY, EXISTENTIALISM.

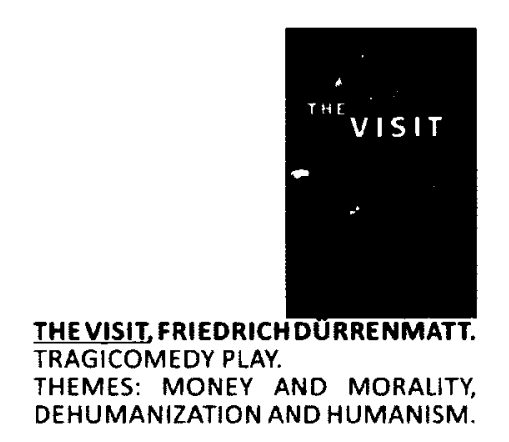

Cookie-cutter houses are spread out or stacked in clusters, and either case the problem today is nobody knows their neighbours, because the distance between people are too far or too close in the wrong direction.

The suburb fails to be countryside because it is too dense. It fails to be a city because it is not dense enough, or organized enough. Countless scattered houses dropped like stones on neat rows of development lots do not create an order, or generate community. Neighbours remain strangers and the real friends are most often quite far away. The husband suffers the necessity of long-distance commuting, but the housewife who remains behind suffers the far greater pain of boredom. ${ }^{1}$ And most importantly, where do the children play?
THE VISLT

(Conversation of two strangers)

(PERFORMED AND RECORDED BY AUTHOR)

"There are only two types of story in history: Either I visityou, or you visit me"

"That was the idea.

Nowadays nobody visits anybody."

"True.

Is it the visitor, or is it the house who is not fit?"

"Either or. One must revisit himself to house-sit." 
We are in touch with the whole world without moving from our seat. (We do not even support the weight with our feet; instead there are design legs (of a chair) or mechanical cheeks where we rest our buttocks on.) We never run into others, but we only sense the neighbours' presence when their noise level or taste in cars does not agree with our own, and that diversity somehow disturbs our peace of mind. Such clusters of housing plans, whether in the suburb or in the core of a city, "pay no attention to these closely linked overwhelming changes, and pretend to be a village of closely knit neighbours and friends. The men, women, and children of suburbia are seldom quite together, and never quite alone."

"A large portion of our lives-working, sleeping, playing-is spent in buildings: buildings over whose design and construction we have little or no control; buildings whose effect upon our health and happiness is only obscurely understood." ${ }^{3}$

Not only we box ourselves in, we are constantly plugged - that is double or triple blockage from the reality; $\bullet$ ears plugged with headphones, brain plugged with external hard drives, hands plugged with (touchscreen) buttons. Do we rely on the biological features or more on the mechanical/ electrical gadgets we attach to our limbs and the box? "In the process of building his mechanical extensions, man has all but lost himself",

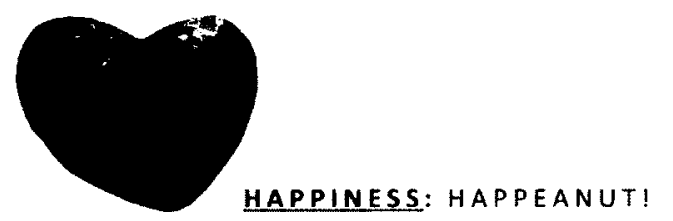

HAPPINESS: HAPPEANUT!
THE BOX MAN, KOBO ABE.

THE NAMELESS PROTAGONIST GIVES UP HIS IDENTITY AND THE TRAPPINGS OF A NORMAL LIFE TO LIVE IN A LARGE CARDBOARD BOX HE WEARS OVER HIS HEAD. WANDERING THE STREETS OF TOKYO AND SCRIBBLING MADLY ON THE INTERIOR WALLS OF HIS BOX, HE DESCRIBES THE WORLD OUTSIDE AS HE SEES OR PERHAPS IMAGINES IT.

- VIRTUALINSANITY, JAMIROQUAI. FUTURES MADE OF VIRTUAL INSANIT NOW ALWAYS SEEM TO BE GOVERNED BY THIS LOVE WE HAVE FOR USELESS, BYISTING, OUR NEW TECHNOLOGY NOW THERE IS NO SOUND FOR WE AL LIVE UNDERGROUND.... 
"Man sees man at his own scale more and more rarely. He sees him in the city and on the highways, and on the two dimensional techniscreen. He hears him on the telephone and over loudspeakers. But it is not until he unplugs himself from these various contrivances that he is exposed as a real living being. It is only then, when he is in his unique natural condition, face-to-face with another that the historic scale relationship between his own physical structure, that of his fellows, and the dimension of his immediate environment is to be found, and only then that genuine intercourse becomes possible."5

"The concrete relationship of one individual to another has lost its direct and human character and has assumed a spirit of manipulation and instrumentality."6 Nobody visits anybody, hence the personal space, or $M a$, between one and another stranger becomes virtually infinite, allowing one the urge to extend, fill, and cover the infinite distance.

1 CHERMAYEFF P63.

2 CHERMAYEFF P64.

3 JAMES MARSTON FITCH. AMERICAN BUILDING: THE FORCES THAT SHAPE IT NEW YORK: SCHOCKEN

4 CHERMAYEFF P77.

5 CHERMAYEFF P76.

6 ERIC FROMM. ESCAPE FROM FREEDOM. LONDON:
What do we need for a biological optimum? How do we define these needs in terms of cubic feet of filled and empty spaces? Nevertheless this covering of distance does not measure our fitness or happiness. Then how do we measure our fitness and happiness? If not by the size of one's personal space or by how to fill up one's space, then it is by rethinking one's personal space. The purpose and intention of the HOUSE is to have individuals able to visit oneself and neighbours and become face-to-face with personal distances. The HOUSE is to have the inhabitants aware of their behaviour, habits and every specific moment in relation to their surroundings, thus to improve their perception and attitude. 
Thank you for your attention this far.

Let's stand up and stretch.

(Was your seat comfortable...?)

We could play musicalchairs to yether.

I hope you find a new seat to settle in.

0
2
1
1
3
0
3

Now we shall proceed to

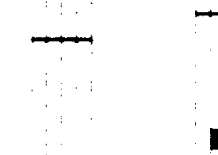

1

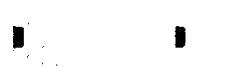

the Visit of the HOUSE 


\section{OPEN HOUSE THE ONE THAT FITS IN YOUR DIET PLAN}

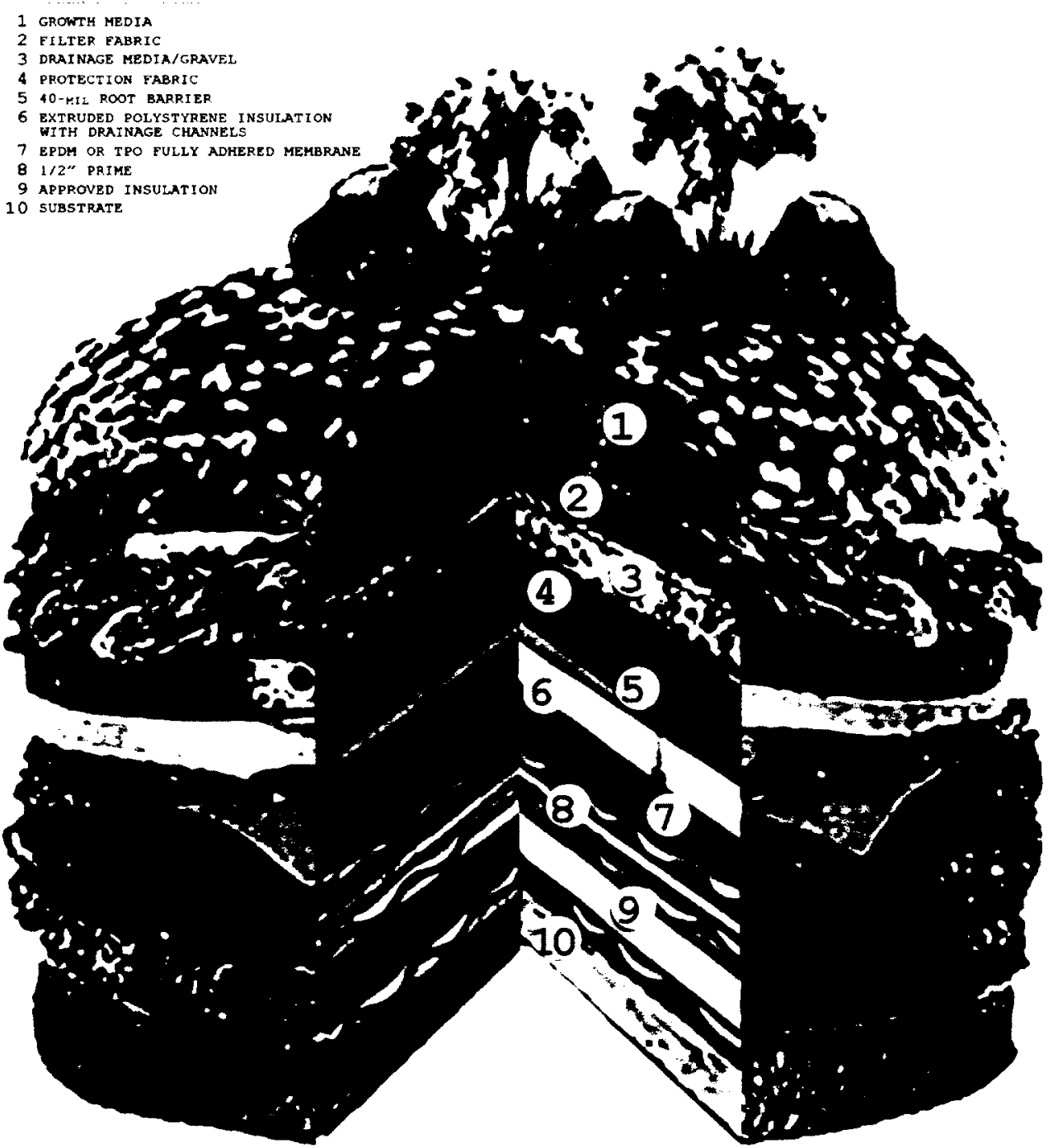


ACT 2 THE VISIT

SITE

HOUSE
UNITS

UNIT $\# 00$

UNIT \#01:

UNIT \#02:

UNIT \#3:

UNIT HOA:

UNIT \#05:

UNIT \#06:

UNIT \#07:

UNIT \#OS:

UNIT

UNIT \#10:

UNIT\#11:

UNIT \#12

UNIT\#13:

UNIT \#14:

UNIT \#15:

UNIT\#16\#17

UNIT \#18:

UNIT \#19:

UNIT $\$ 20$ :

UNIT \#21:

UNIT \#22:

UNIT \#23:

CONCLUSION

POSTSCRIPT

BIBLIOGRAPHY
PROJECT HOUSE

47

49

56

HUB FOR PUBLIC GATHERING

HOME FOR ELDERLY AND PHYSICALLY CHALLENGED

HOMEFOR HALLWAY LOVERS

HOME FOR GROWING

HOME FOR CLIMBING

HOME FOR OUTDOOR LOVERS

HOME FOR TINY PEOPLE AND CLAUSTROPHOBES

HOME FOR ACHIEVING MAXIMUM DISTANCE WITHIN

HOME FOR SMOKERS

HOME FOR TIDY PEOPLE

HOME FOR MERRY-GO'ROUND

HOME FOR MEDIAN STRIP LOVERS

HOME FOR DROPPED CEILING LOVERS

HOME FOR ARTISTS AND MINIMALISTS

HOMEFOR MULTI-PERSPECTIVALS

HOME FOR GREEN HOUSE LOVERS

TWO-HAIVES HOME FOR CREATIVE PERFORMERS

HOME FOR TRI-GENERATION FAMILY

HOME FOR BI-GENERATION FAMILY

HOME FOR ROMANTICISTS AND ASTRONOMERS

HOME FOR CAT LOVERS

HOME FOR SLOPED ROOF LOVERS

HOME FOR PRO-SOCIAL AND ANTIISOCIAL NEIGHBOURS 


\section{USERS GUIDE TO ACT 2}

$\begin{array}{llllllll}T & E & X & T & U & A & L\end{array}$ DESCRIPTION OF THE UNIT AND ITS INHABITANTS

FLOOR PLAN $(1: 1000)$ AND UNIT LOCATION

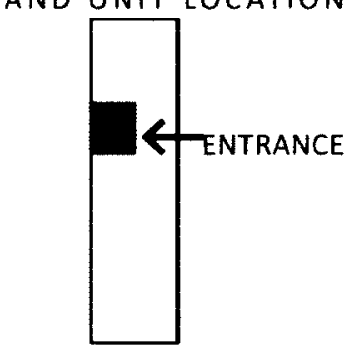

OVERALL MASSING

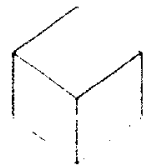

$\begin{array}{lllll}V & I & S & U & A \\ \text { DIAGRAMS }\end{array}$

(ALL VISUALS BY AUTHOR)

AXONOMETRIC (SCALE 1:200)

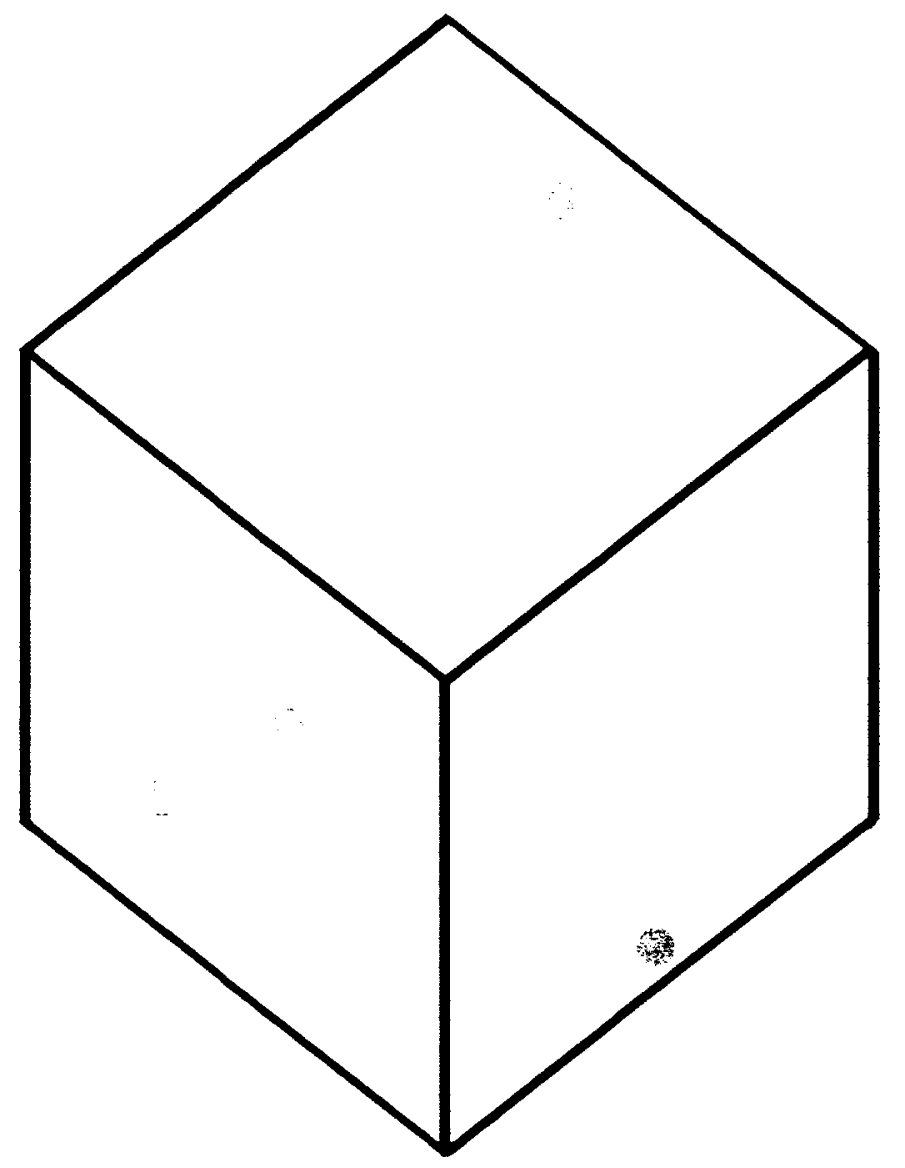

LEGEND OF DETAILS

- 


\section{ACT 2 THE VIS IT \\ 0. S I T E}

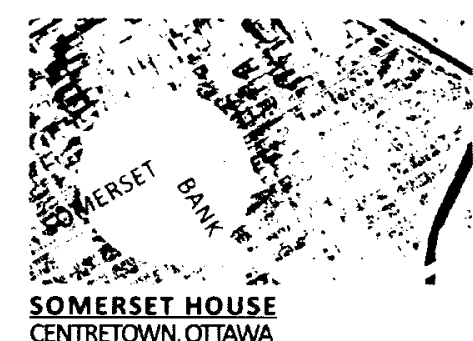

SOMERSET HOUSE
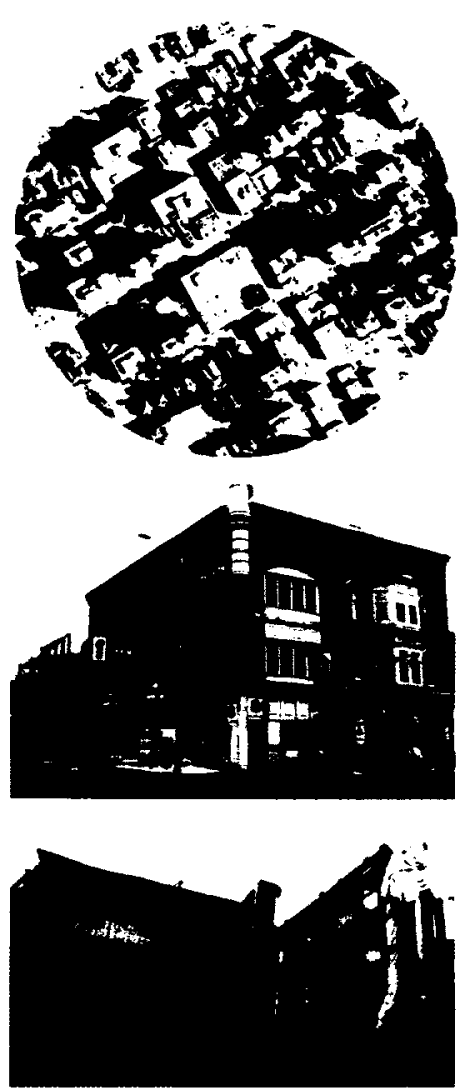

SOUTHEAST CORNER, DAVID KAWAI THE SOUTHEAST CORNER AND THE 4TH FLOOR DEMOLISHED BY THE CITY TO ALLOW INSPECTORS COMPLETE ACCESS TO ASSESS THE BUILDING'S STABILITY.
Somerset House, once home to such Ottawa landmarks as the Ritz Hotel and The Duke of Somerset, has now sat empty for nearly six years. It has been sheathed with metal scaffolding and exterior support beams, an ugly eyesore at one of the major intersections in the nation's capital. "The city bears most of the responsibility for what has happened to Somerset House," says Derek Crain, president of the Somerset Village Business Improvement Area, as well as an architect who has been trying to restore the historic building.

When Tony Shahresebi purchased it from Mitchell, the original owner, in 2005, he imagined another restaurant operating on the ground floor with renovated apartments above. He would restore the building to its former glory. He came up with a renovation plan and got to work:

Then on October 19, 2007, while a work crew was in the basement, part of the southeast wall collapsed. With no engineering report to back up the initial assessment, the city ordered the intersection closure, and in early December the city came up with a solution to the problem. It would tear down Somerset House.

"Why barricade four blocks?" Shahresebi asks. "They put up roadblocks at every opportunity. Some days it seemed like I was being hanged in red tape, like I was being punished just because I asked the city why they tore down my building. My engineer, my architect, my lawyer, none - of us could believe it when we received the demolition order. The city didn't even know how badly the building was damaged, but they were going to tear it down anyway."

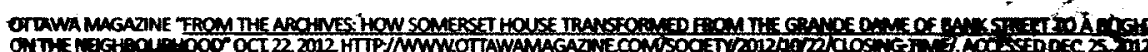

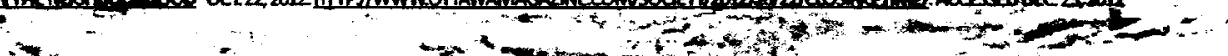




\section{SITE DIAGRAM}

SOMERSET HOUSE @ BANK / SOMERSET

CURRENT CONDITION AND CONSTRUCTION PLAN
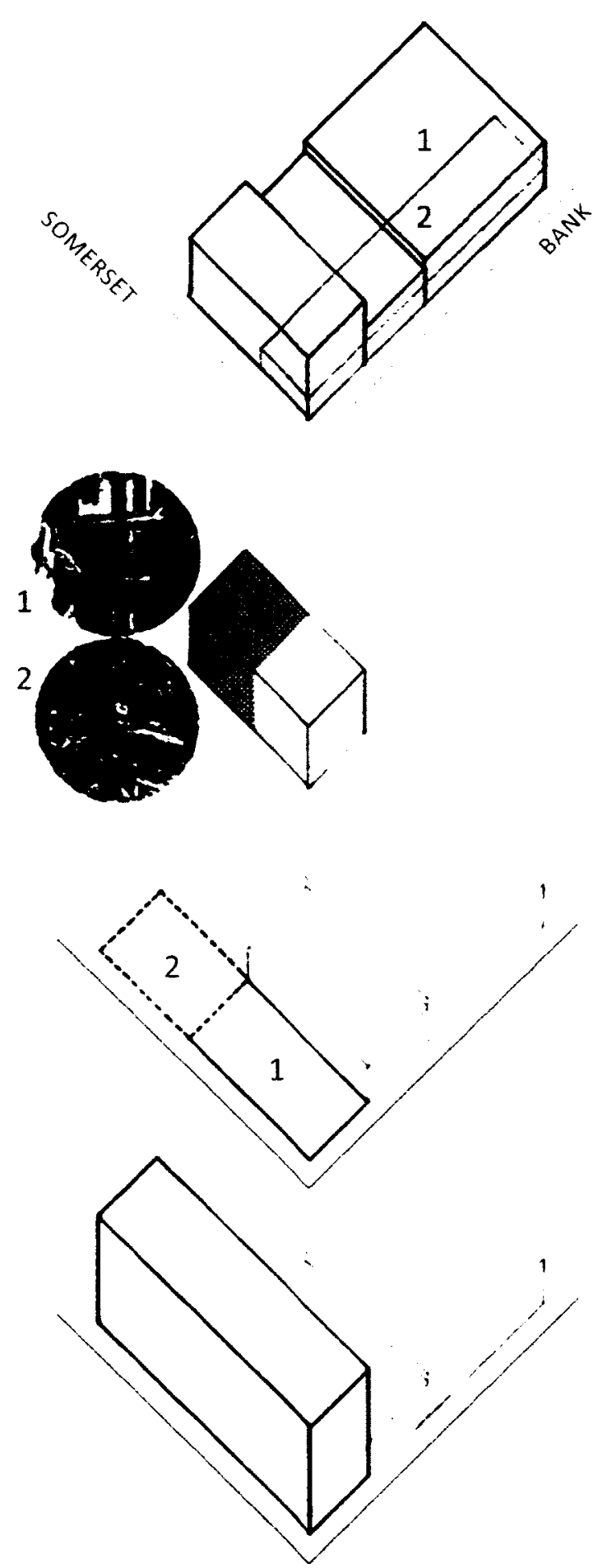

BANK STREET ELEVATION

1 RESIDENTIAL: 2ND, 3RD FLOORS

2 COMMERCIAL: GROUND FLOOR
CURRENT CONDITION (STRUCTURE FAILURE 2007)

COLLAPSED WALLS

2 COLLAPSED FLOORS

\section{SITE RECONFIGURATION}

(DEMOLITION AND EXPANSION)

1 EXISTING DEMOLISHED

2 EAST EXPANSION
PROJECT CONSTRUCTION

(TOTAL BUILDABLE VOLUME) 
1. $\mathrm{HOUSE}$

\section{HOUSE DIAGRAM}

FACADE / VOLUME RELATIONSHIP PUBLIC / PRIVATE BALANCE TIME / SPACE TRANSFORMATION

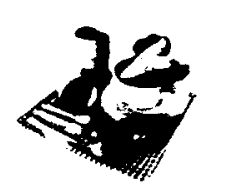

asis

$\operatorname{lom}^{7}$

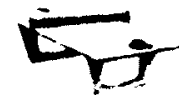

0

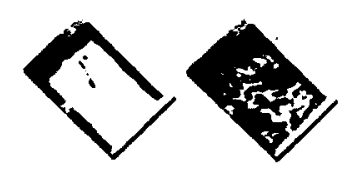

52

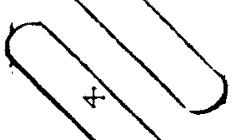

$+$

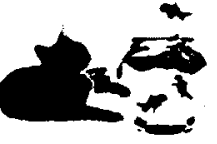

ब०त

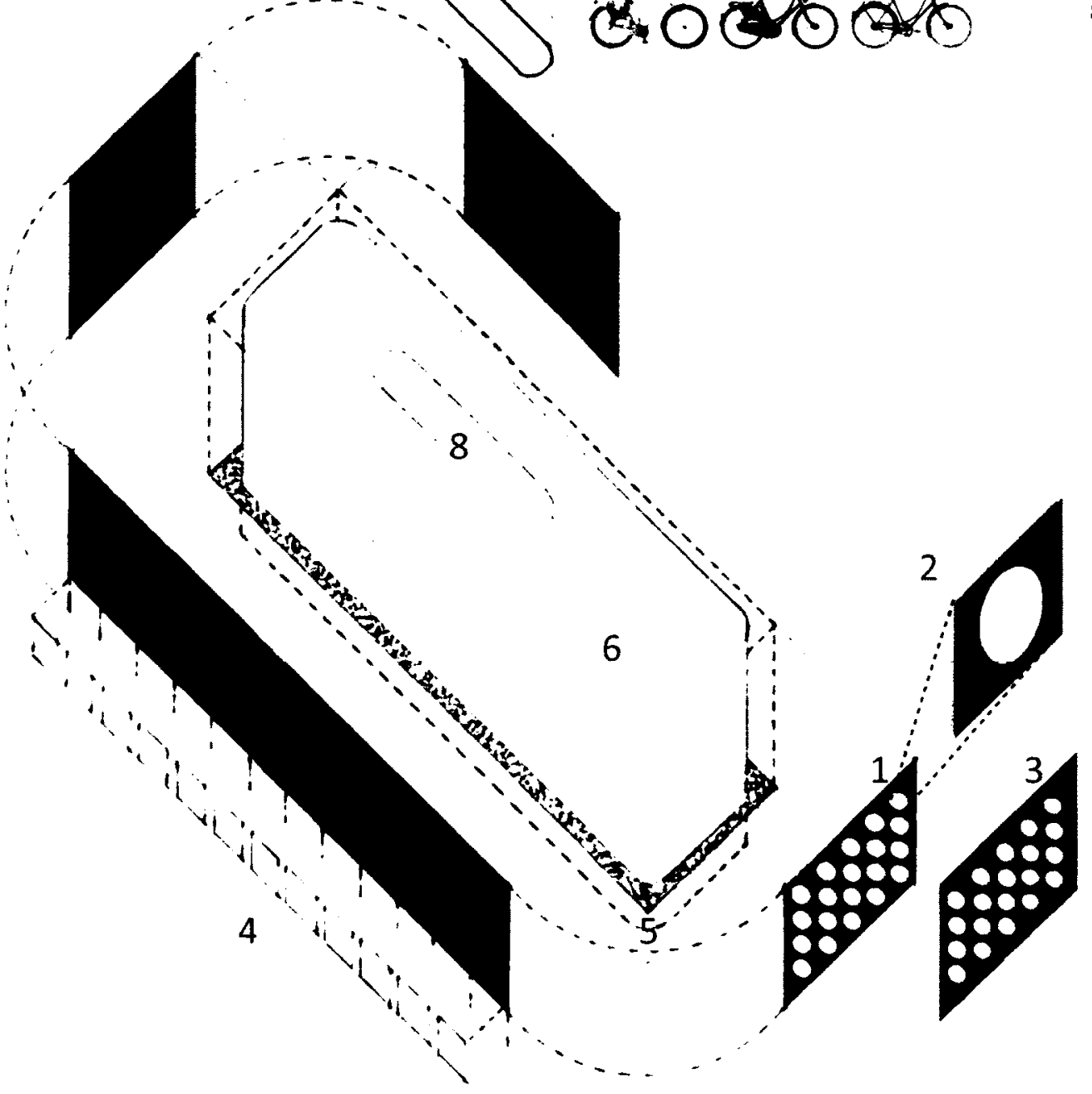

1 FACADE: PERFORATED COPPER PANEL

2 FACADE PERFORATION: A VIEW FINDER BIRD NEST

3 FACADE DECAY: OXIDATION OVER TIME 4 TRANSLUCENT SCREEN PANELS HOSTING: SEMI-PUBLIC / PRIVATE SEASONAL EVENTS COMMUNITY ACTIVITIES

5 GRAVEL PERIPHERY: RAINWATER DRAINING BAMBOO PLANTING

6 DWELLING VOLUME

7 CENTRAL CORE:

STAIRCASE + DUMBWAITER RECREATIONAL + GATHERING 8 WATER POLES: COLLECTS PRECIPITATION STORES UNDER GROUND 
CONCEPTUAL IMAGE

INSPIRED BY BOXMAN (KOBO ABE), A MAN FINDS A HOMELESS SITE AND CONSTRUCTS A FITTED SKIN TO SHELTER HIMSELF, YET ALLOWING THE EXTERNAL CONDITIONS TO INTERACT WITH HIS BODY HERE IS

THE BIRTH OF A SENSIBLE AND CORPOREAL BOXMAN IN THE HEART OF THE CITY.

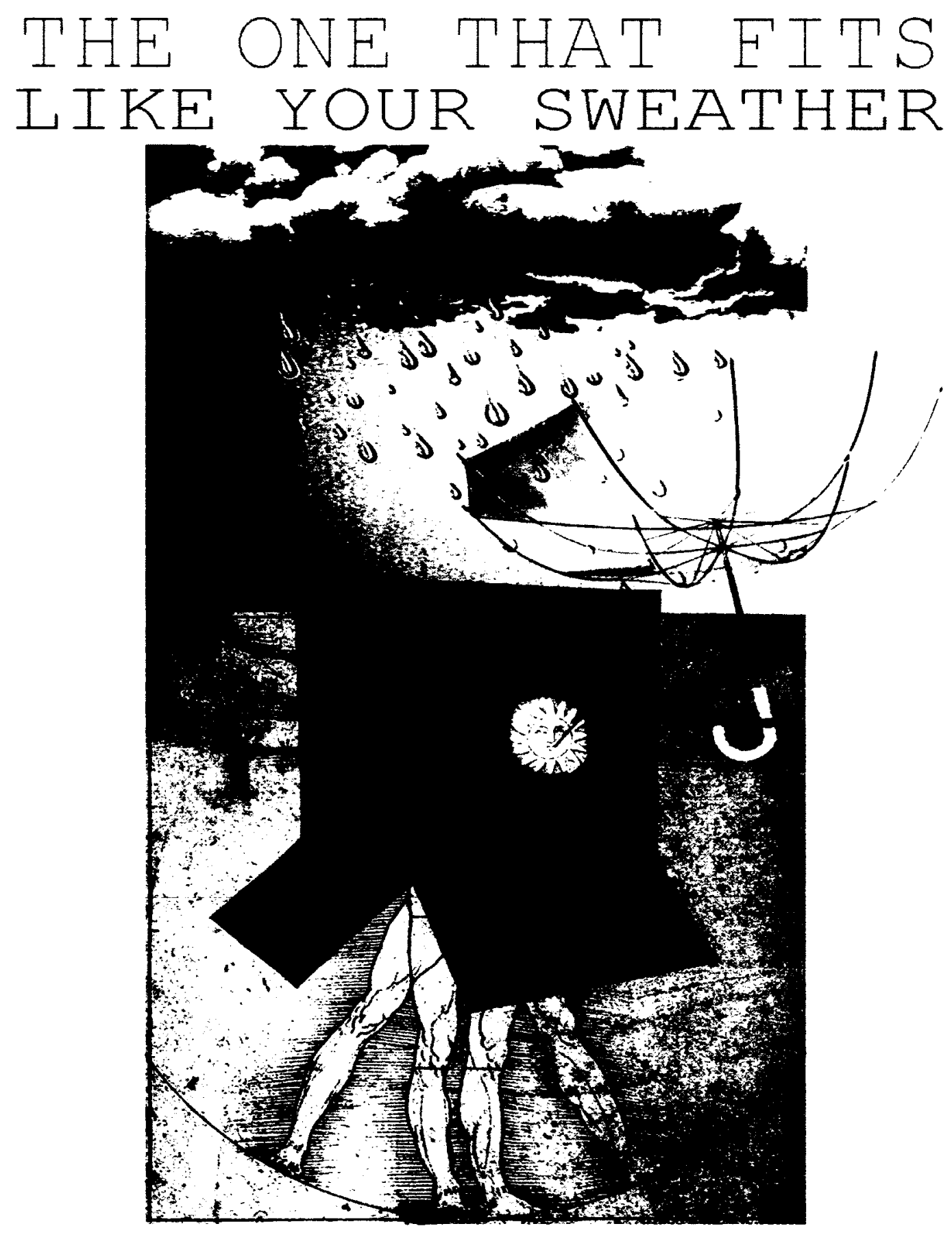




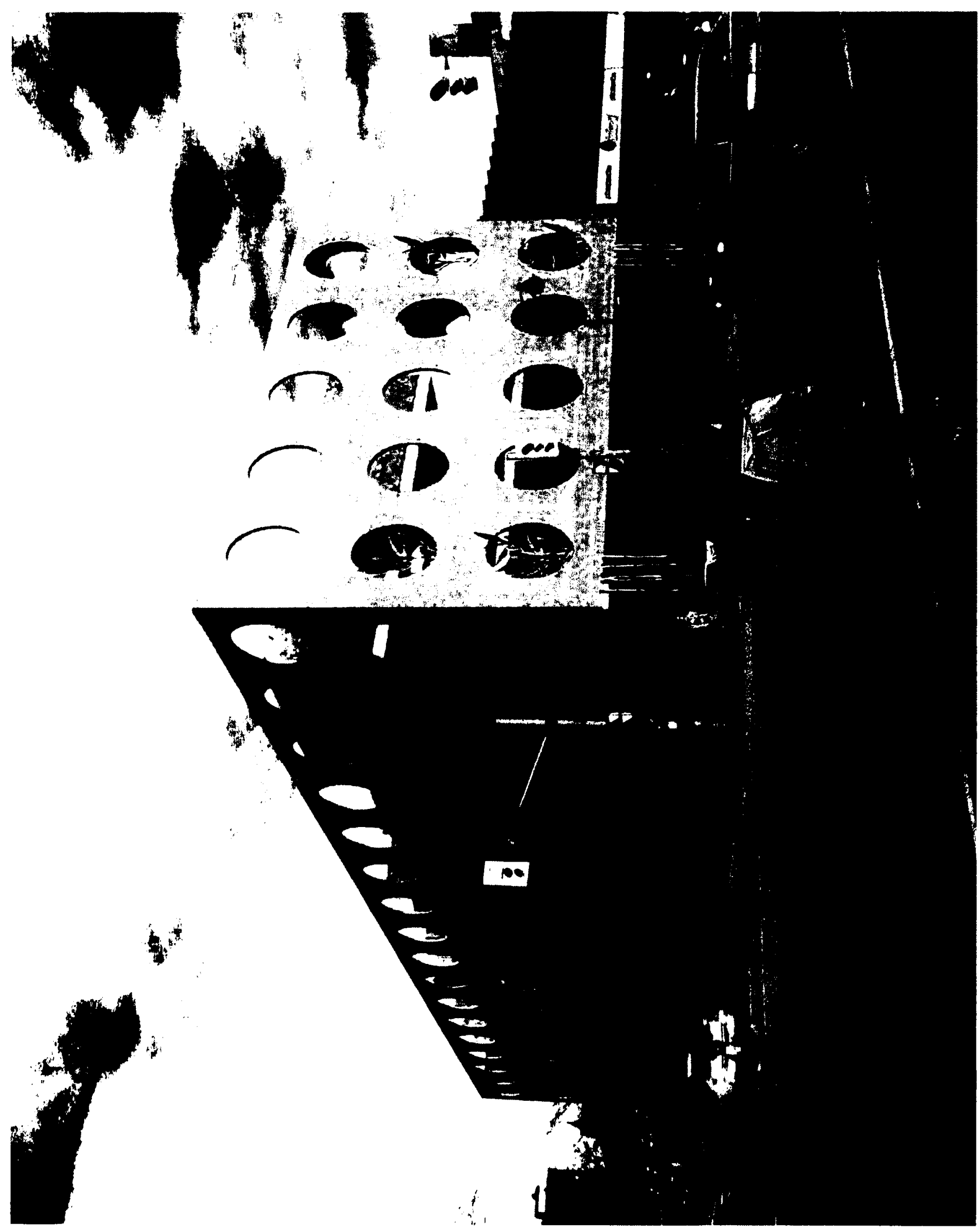


HOUSE SECTION (E-W)

VIEWED FROM SOMERSET
1 COMMUNAL ROOFTOP GARDEN

2 DWELLING VOLUMES: HOUSING UNITS

3 MAIN STAIRCASE WITHIN THE CIRCULATION CORE

4 DUMBWAITER WITHIN THE CIRCULATION CORE - (REFER TO THE FOLLOWING SCENE FOR DETAILS)

5 HUB FOR PUBLIC GATHERING

(PUBLICLY OR PRIVATEIY OWNED BUSINESS)

6 COMMUNAL SPACES FOR EVENTS AND GATHERINGS

WITHIN THE CORE ON ALL LEVELS
7 UNDERGROUND FOR STORAGE, LAUNDRY, MECHANICAL

FIXTURES, WATER TANKS

1

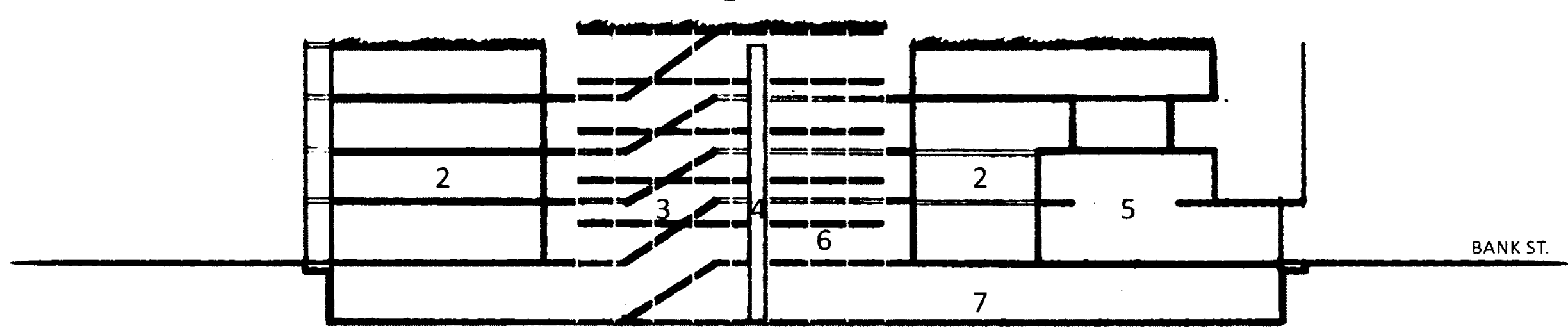


G $\quad 0 \quad$ I $N$ N AGAINST AND ALONG $\begin{array}{llllllllllllll} & G & R & A & V & I & T & Y\end{array}$

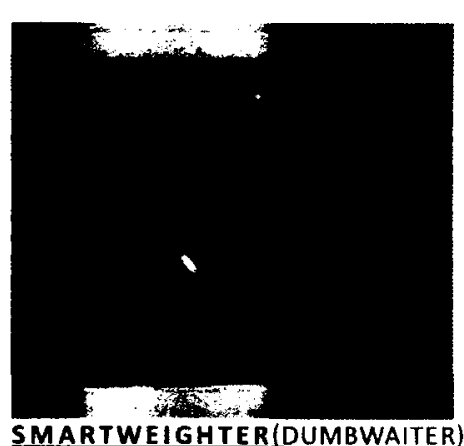

SMARTWEIGHTER(DUMBWAITER)
If you are thinking about getting in shape, try the smartweighter! Firstly, you must be fit in order to fit; secondly, you must be fit in order to lift yourself.

Those who go to the gym to lift weights, well, stop lifting the weights that are not related to you. Have you thought about being able to lift your own weight? (Or, you might as well be a dumbwaiter!) Those who are lazy still get to sit (or stand) in a box without displacing your feet. Those who have other (inconvenient) reasons to take (convenient) elevators will simply feel better for working out the mechanism by themselves and for themselves.

Traveling against gravity (without technological help) is not easy. But we are not talking about shooting ourselves up to the moon, and technology does not mean high-technology. If we recover the lost-technologysmart mechanisms worked out by ancient civilizations-we could basically displace our positions to the appropriate altitude according to the needs. This way, we will not contradict ourselves by saying 'let's save energy' while taking an elevator and still complaining how slow it is. We are not even saving our own energy by taking elevators; our energy only gets trapped in the body, and eventually explodes in the form of permanent bad mood and impatience, and unfit physique. We can save the outsource energy (electricity, heat, so on) by utilizing our own energy (in which case of course we need to eat well, sleep well, dream well, and so on, to produce kinetic energy). However once we get used to the constant input (efficiency in action), then we will consequently get things in a better form than we have imagined (productivity in performance).

Now, please allow me to introduce the following two applications of losttechnology: smartweighters. 
MANUAL ELEVATOR I:

CLASSICAL PULLEY SYSTEM

VERY SIMPLE. TWO STRINGS INSIDE A BOX: ONE TO PULL YOURSELF (IN THE BOX) UP, ANOTHER TO PULL DOWN. IT MAY REQUIRE SOME ARM STRENGTH, BUT NOW YOU NO LONGER NEED TO DO PUSHUPS AGAINST THE FLOOR OR THE WALL, WHICH DOES NOT GET YOU ANYWHERE.

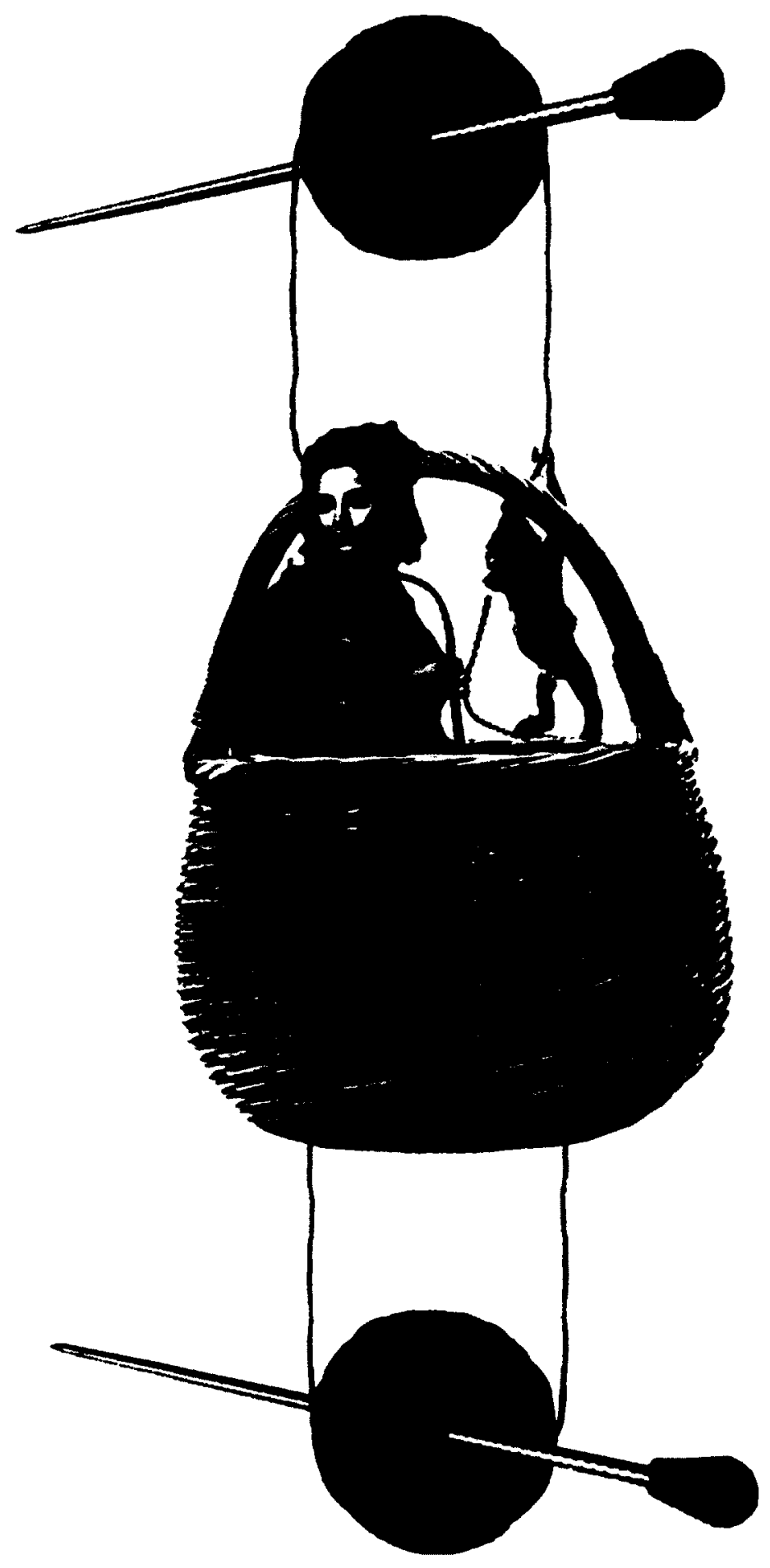




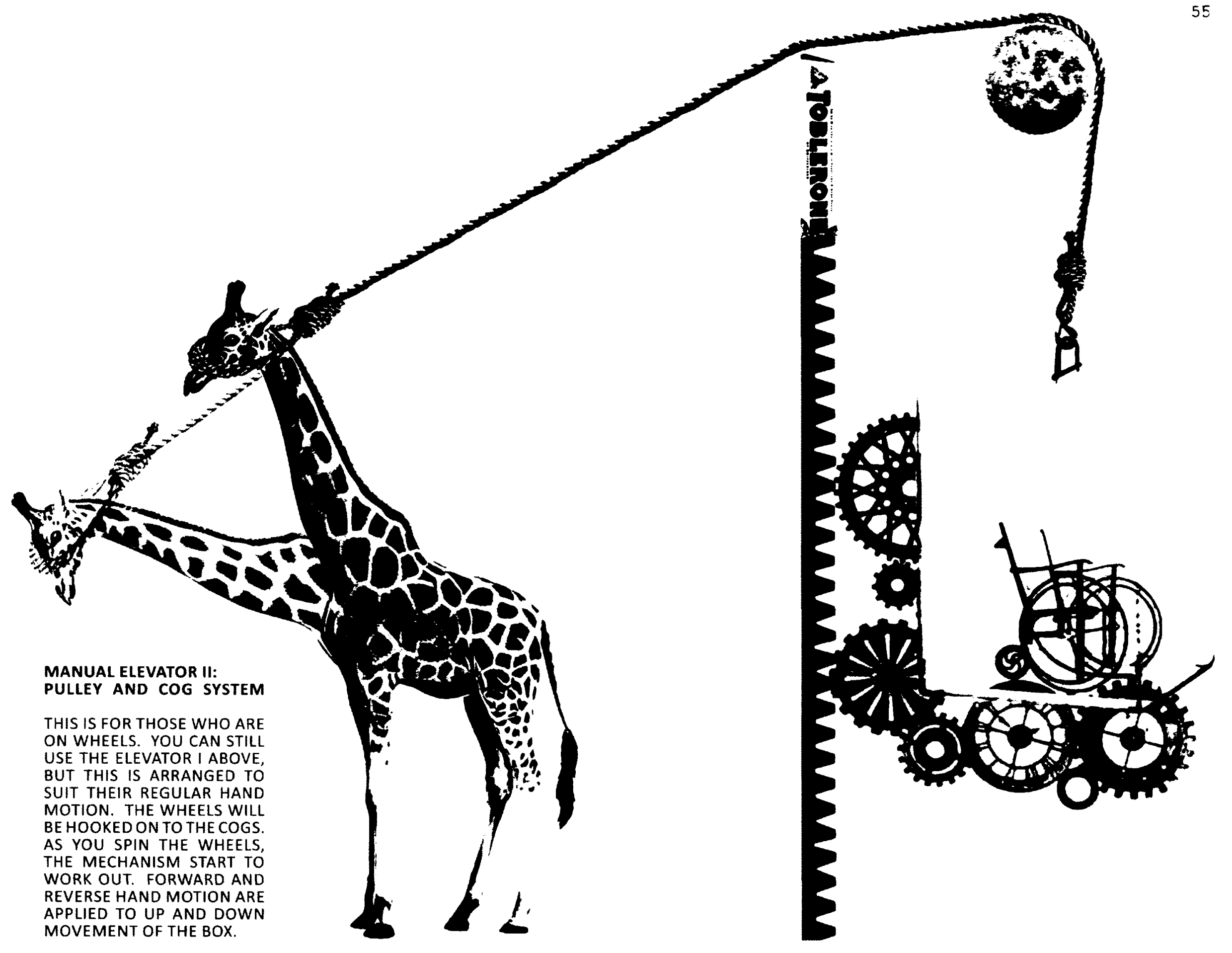


2. U N I T S

U N I T \# 0 o

HUB FOR PUBLIC G A T H E R I N $\mathbf{N}$

FACING BANK STREET, THE HUB, HALF WITH AN OUTDOOR PATIO ANOTHER HALF WITH DOUBLE HEIGHT ATRIUM, ALLOWSPLENTY OF DAYLIGHT IN THROUGH THE GLAZING AND PERFORATED FACADE. ENTRANCE IS LOCATED AT THE CENTRE, UNDER THE RAISED FACADE. THE ENTRANCE IS INSET, WITH A COPPER DOOR, WHICH REFLECTS THE MATERIALITY OF THE FACADE, ALONG WITH THE REAR WALL TO ENTER, ONE MUST PASS OVER THE GRAVELSTRIP,WHERE EXCESS SNOW, RAINWATER OR DIRT ON THE SHOES CAN BE SHAKEN OFF AND DRAINED. THE GRAVEL CAN AS WELL HOST PLANTS SUCH AS BAMBOO TO GROW FOR THEIR FULL HEIGHTIN THE INTERSTITIAL SPACE BETWEEN THE VOLUME AND FACADE.

THE VOLUME CAN BE A CAFE, RESTAURANT OR GALLERY, OR A COMBINATION OF MULTIPLE TYPES OF SOCIAL GATHERING SPACE. IT IS OPEN TO PUBLICLY OR PRIVATELY OPERATED BUSINESSES.

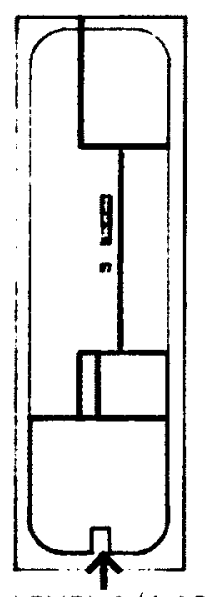

LEVEL 1 (1:1000)

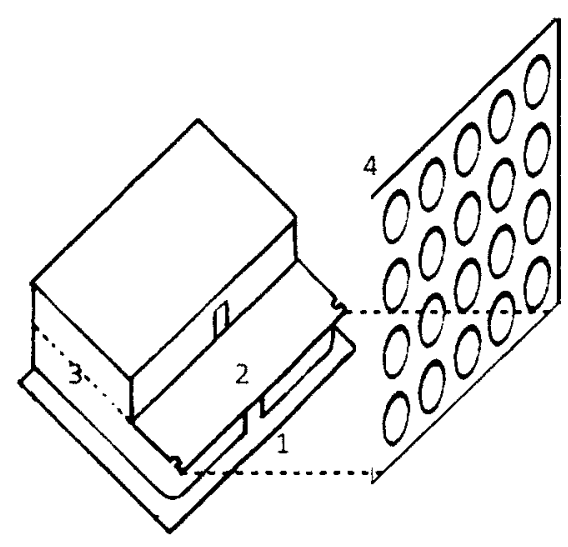

1 ENTRANCE

2 PATIO

3 DOUBLE-HEIGHT ATRIUM

4 FACADE

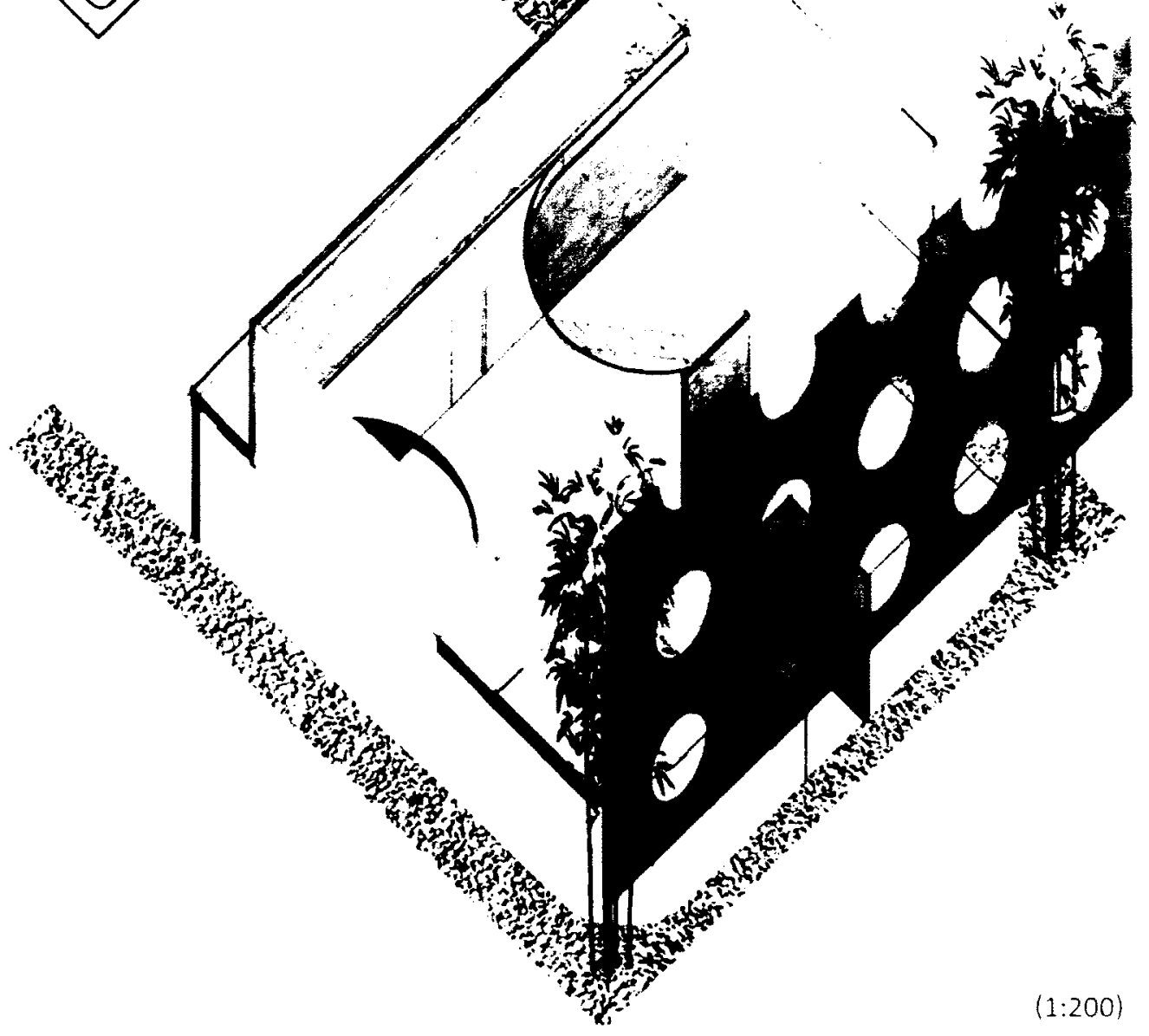




\section{U N I T \# 01}

HOME FOR

ELDERLY AN D P H Y S I C A L L Y C H A L L N G E D

LOCATED ON THE GROUND LEVEL, GENEROUS FLOOR AREA, ENTRANCE WAY AND ROUNDED CORNERS ALLOW INHABITANTS WITH MECHANICAL OR
MEDICALASSISTANCE TO MOVE AT EASE. THE BATHROOM IS MORE SPATIAL COMPARED TO ALL OTHER UNITS, SHEETED
WITH BAMBOO TO REDUCE THE IMPACT OF COLD HARD FLOOR

IT IS THE ONLY UNIT THAT COMES WITH A FIREPLACE, FOR EXTRA VISUAL AND PHYSICAL COMFORT IN THE WINTER

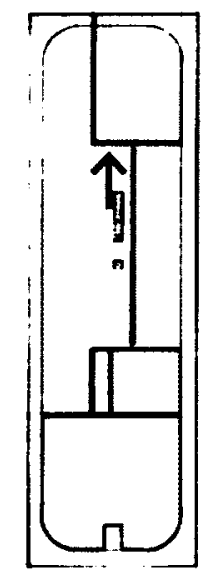

LEVEL 1 (1:1000)
1 ENTRANCE

2 BATHROOM

3 SLEEPING/RESTING

4 COOKING/DINING

5 LIVING

6 BALCONY

7 FIREPLACE

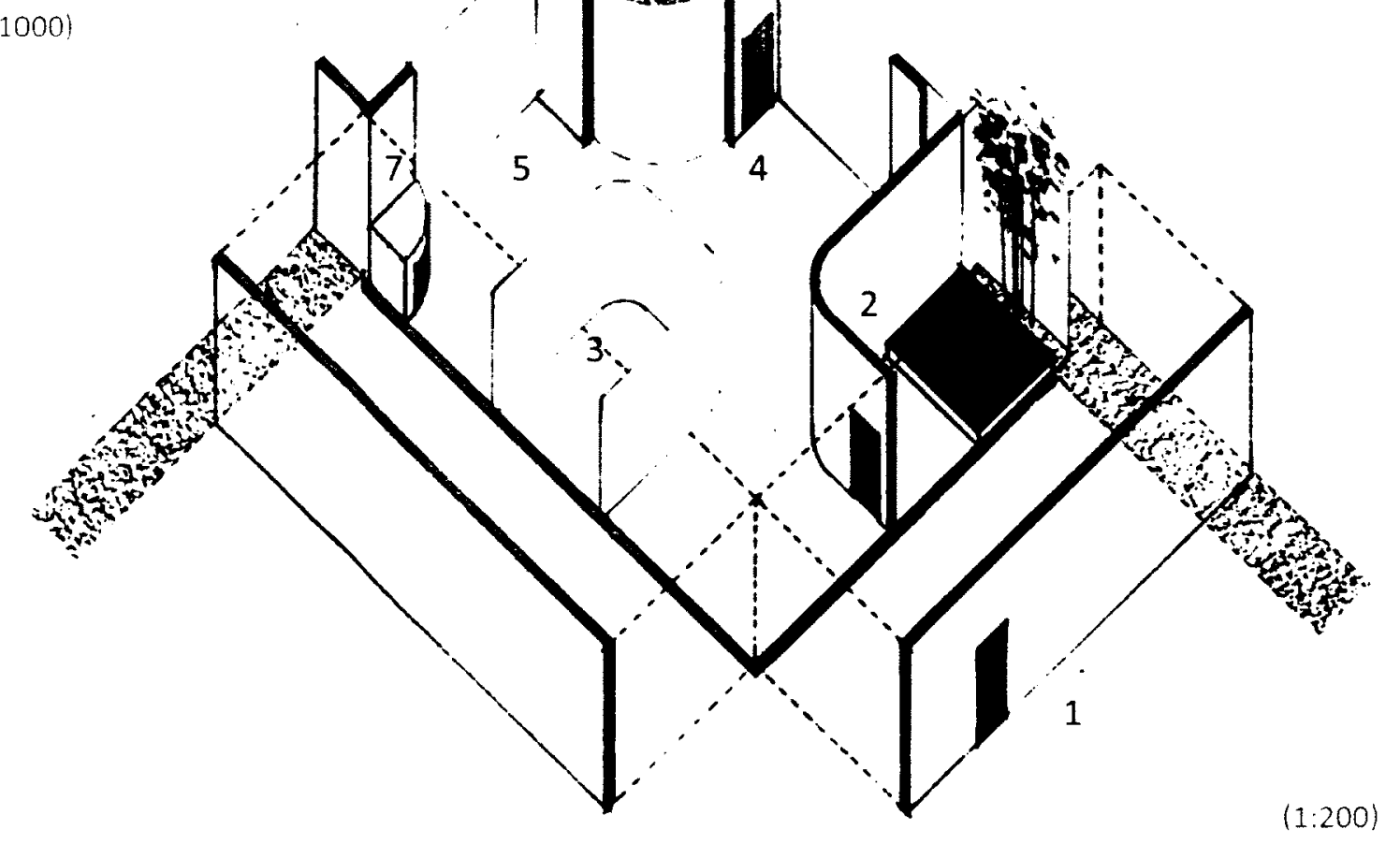


$\mathbf{U} \mathbf{N} \mathbf{T} \# \mathbf{0} 2$

H O M E F O R

H A $\quad L \quad L \quad W \quad A \quad Y$

L $\quad O \quad V \quad E \quad R \quad S$

TAKING THE LONGEST SPAN IN THE BUILDING, THE UNIT FEATURES A TYPICALLY LONG BORING HALLWAY TURNING INTO A SERIES OF FUNWAY FOR HALLWAY LOVERS OR
HATERS, THIS WOULD BE A MUTUAL EXCITEMENT FOR CREATIVE ACTIVITIES, THE UNIT COMES WITH THREE HALLWAY ACCESSORIES: GOLF GREEN, RED CARPET RUNWAY, AND BOWLING LANE. YOU MAY DESIGN YOUR OWN ACCESSORIES WHEN SIGNING UP FOR THIS UNIT.

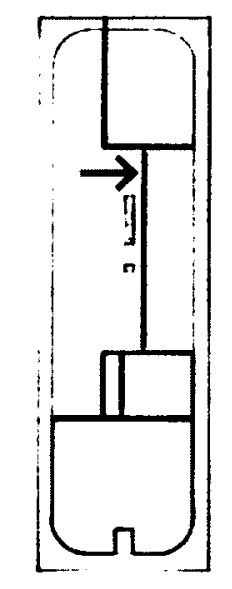

LEVEL 1 (1:1000)
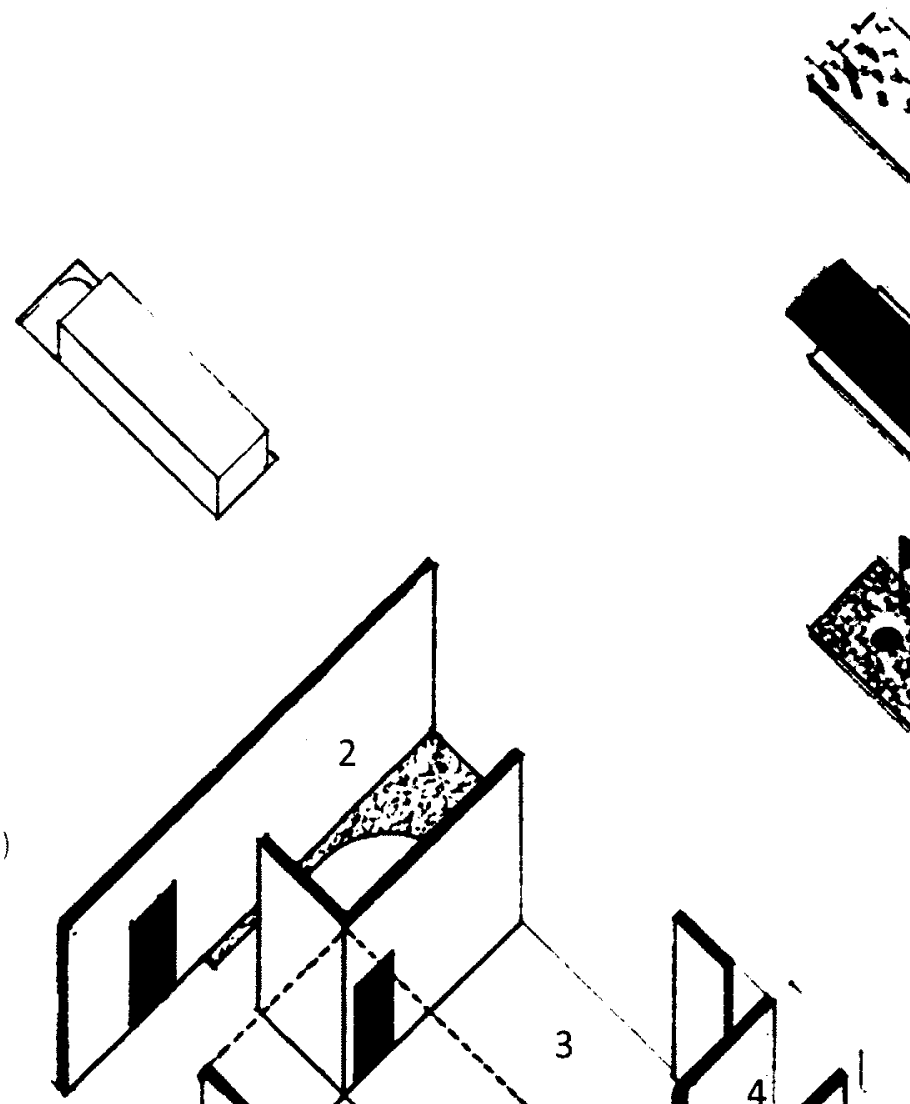

3
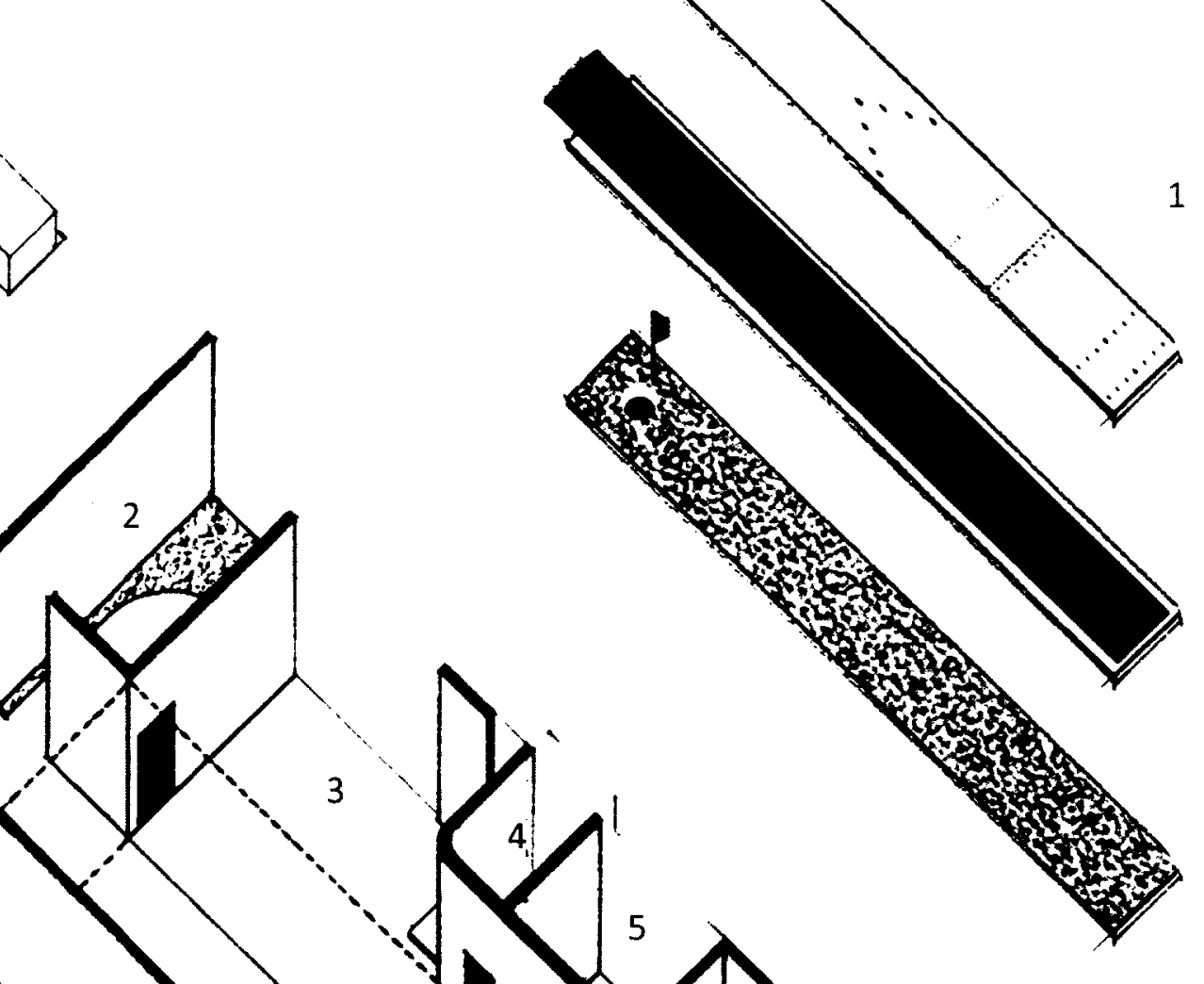

1

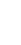

2 ENTRANCE/BALCONY

3 LIVING / DINING/COOKING

4 BATHROOM

5 SLEEPING

6 STUDYING/PLAYING/MEDITATING 


\section{$\mathbf{U} \mathbf{T} \quad \# \mathbf{0} 3$}

H O M E F O R

A THREE-STORY VOLUME FEATURING A COURT FOR PLANTING, ALLOWING THE PLANT TO REACH HIGH ALTITUDE JUST AS YOU CAN ELEVATE UP TO THREE LEVELS. THE UNIT IS FOR OPTIMISTIC PEOPLE WHO LOVE TO GROW THINGS BESIDE/ALONG WITH THEIR OWN GROWTH, OR FOR THOSE WHO ARE SLIGHTLY PESSIMISTIC AND WILLING TO OVERCOME SUCH ATTITUDE. IT IS ALSO HELPFUL FOR THOSE WHO HAVE HORIZONTALLY EXPANDED BODIES TO CHANGE ITS DIRECTION OF GROWTH: VERTICAL STRETCH IN ORDERTO FEEL FIT AND PROPORTIONAL.
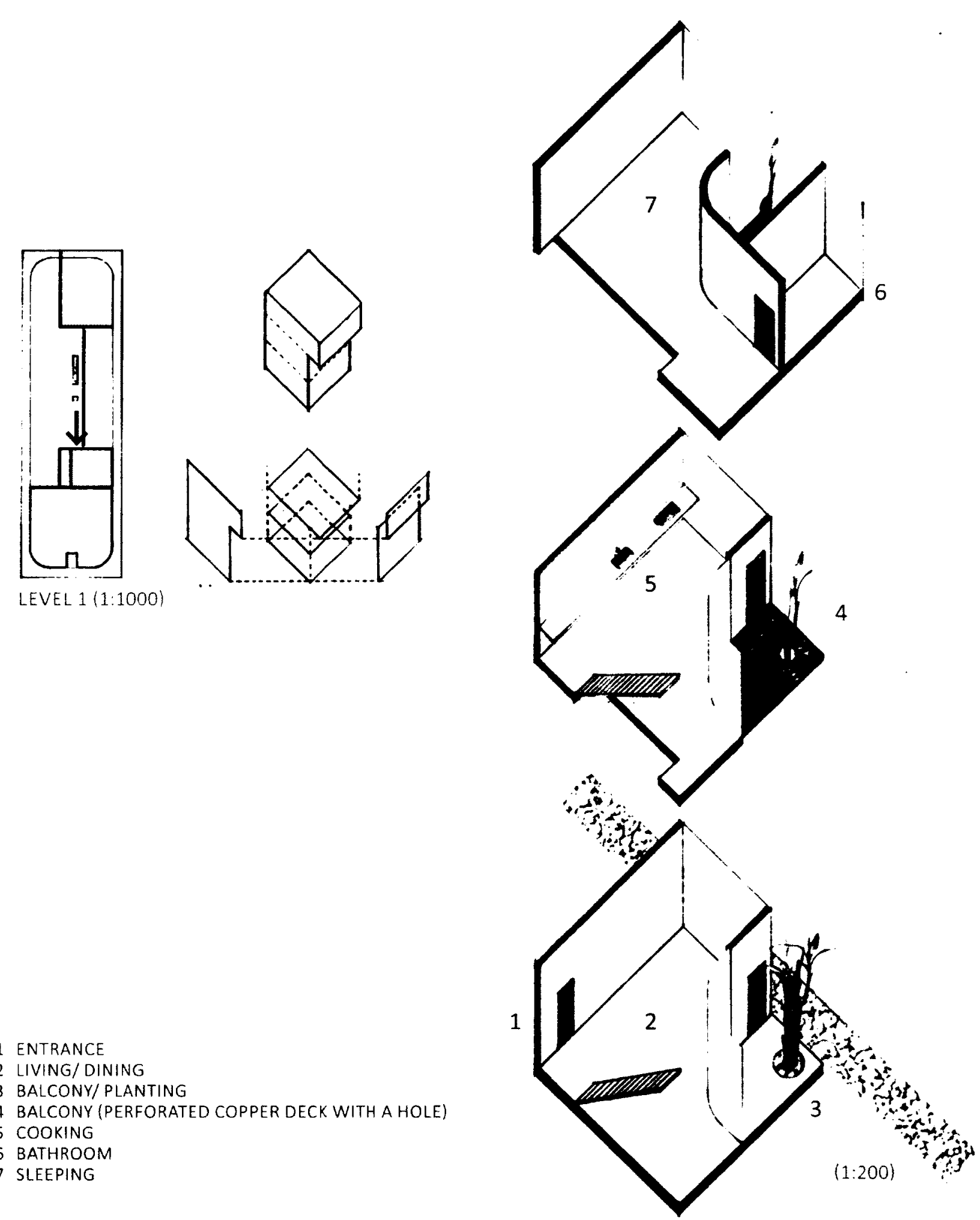

LEVEL 1 (1:1000)

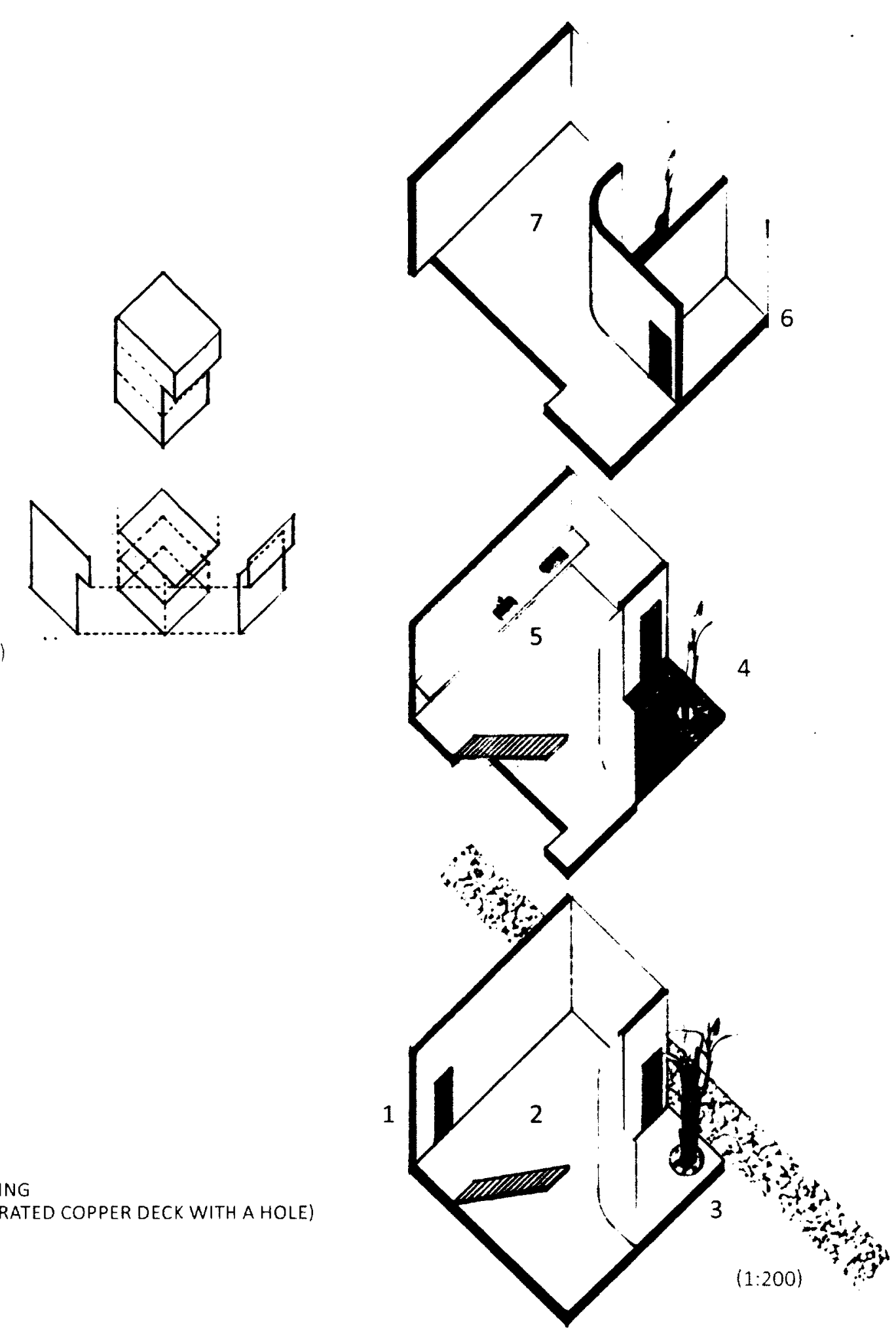

4 BALCONY (PERFORATED COPPER DECK WITH A HOLE) 


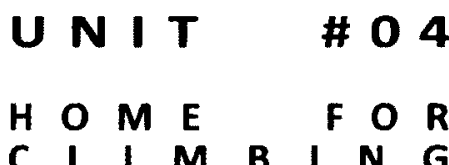

THIS THREE-STORY UNIT PROVIDES A STEEP STAIRCASE AND TWO LADDERS FOR THOSE WHO HAVE CONFIDENCE

IN THIGH AND BUTTOCKS MUSCLES OR FOR THOSE WHO WANT TO STRENGTHEN WHO WANT TO STRENGTHEN OR SIMPLY FOR THOSE WHO ENIOY A SPACIOUS LOFT AND LEVELIED BALCONIES AND LEVELLED BALCONIES. ARRANGE AND MOUNT YOUR OWN HOLDS ON THE VERTICAL SURFACE, IF YOU ARE A ROCK CLIMBER.
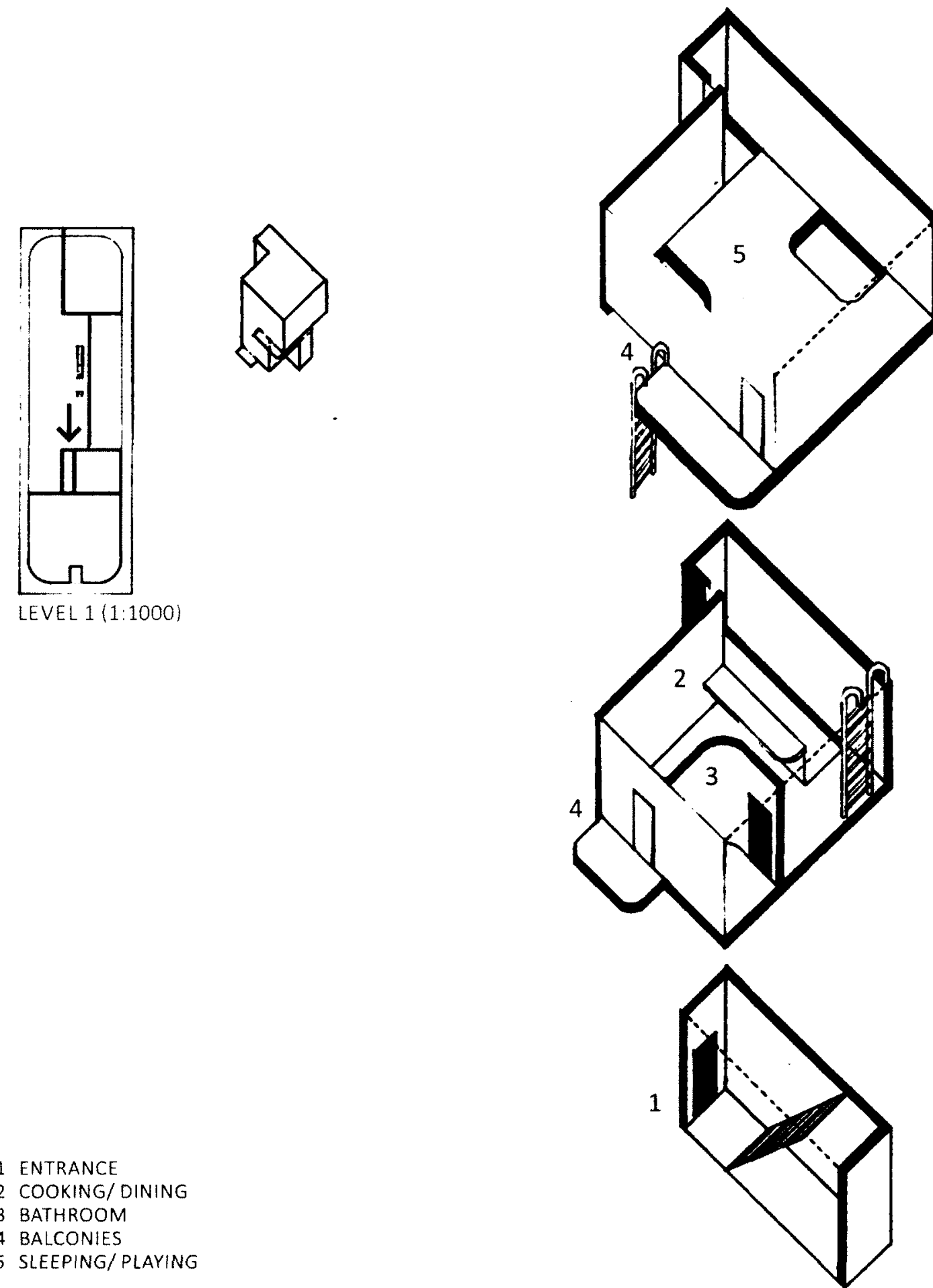

(1:200)
1 ENTRANCE

2 COOKING/DINING

3 BATHROOM

4 BALCONIES

5 SLEEPING/ PLAYING 
$\mathbf{U} \mid \mathbf{T} \# \mathbf{0}$

$\begin{array}{llllllll}H & O & M & E & & F & R \\ O & U & T & D & O & O & R \\ L & O & V & E & R & S\end{array}$

A SMALL CUBE WITH A LOFT CIRCUMSCRIBED BY TWO LEVELS OF BALCONY, ALMOST WRAPPING AROUND THE UNIT PROVIDES AS MUCH OF THE OUTDOOR SPACE AS THE INDOOR VOLUME. FOR A CITY WITH A LONG HARSH WINTER, THIS OUTDOOR AREA IS EXPOSED TO THE LOVELY WEATHERS YET FILTERED BY THE FACADE TO GET A GOOD BALANCE OF SEMI-INDOOR AND OUTDOOR LIGHTING AND AIR QUALITY. IT ALLOWS YOU TO MAXIMIZE THE EXPERIENCE OF THE SHORTLASTING SUMMER.
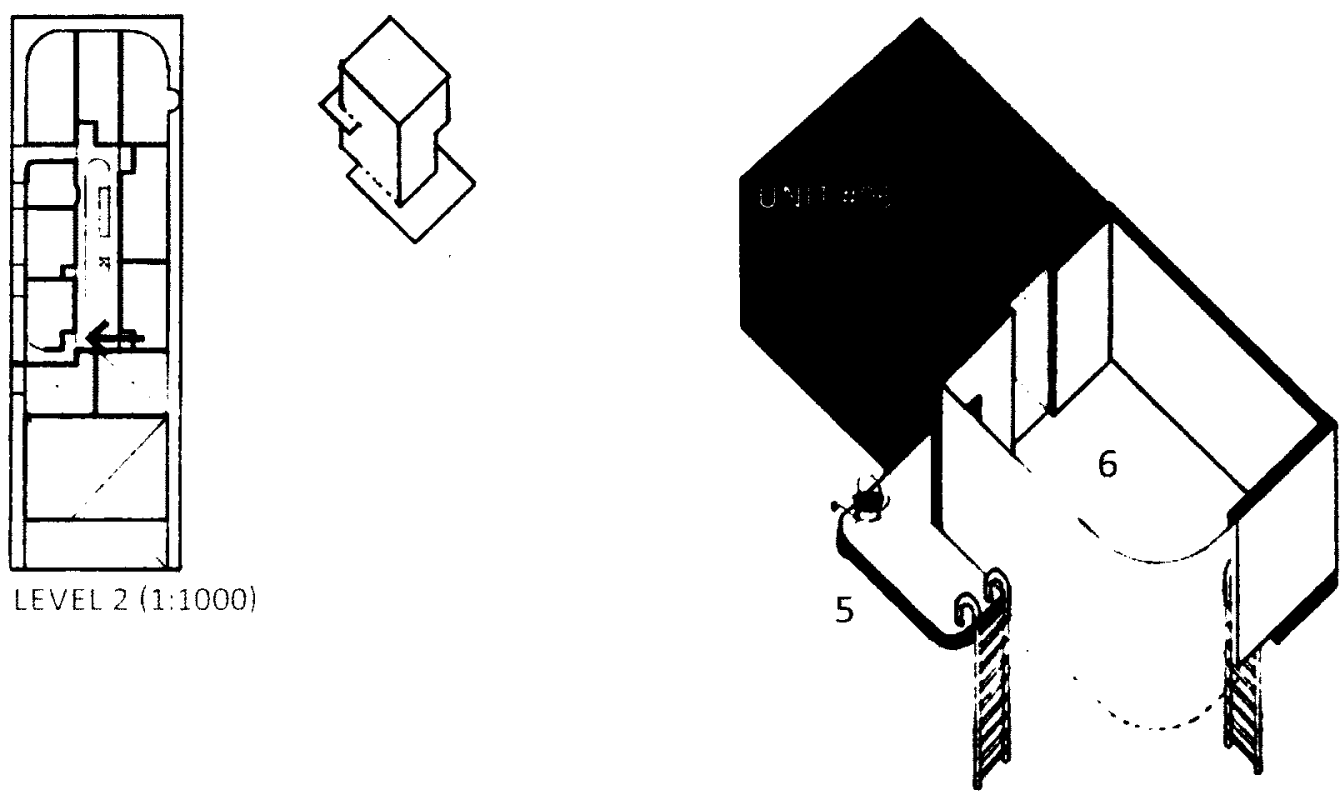

1 ENTRANCE

2 BALCONY/LIVING/PLAYING

3 COOKING/ DINING

4 BATHROOM

5 BALCONY/LIVING/ PLAYING

6 SLEEPING

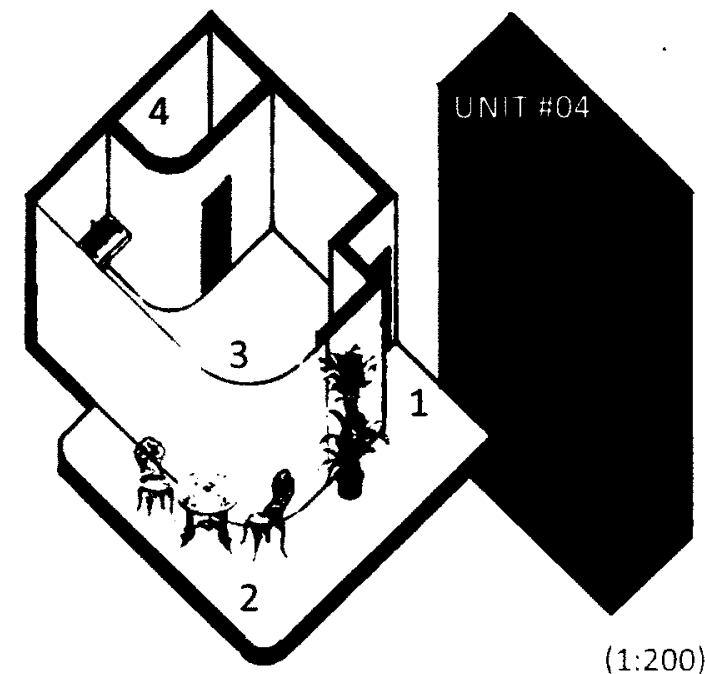


UN T

H O M E FO R T I N Y P E O PLE $\&$

CLAUSTROPHOBES

THE SECOND SMALLEST UNIT IN THE BUILDING IS FOR TINY PEOPLE, ELVES, FAIRIES, OR

CLAUSTROPHOBES (WHO

WANT TO OVERCOME SUCH

PSYCHOLOGICAL STATE). IT PROVIDES ANESSENTIALAND

BASIC SET OF PROGRAMME

TO COMPLETE YOUR DAILY

ROUTINE.

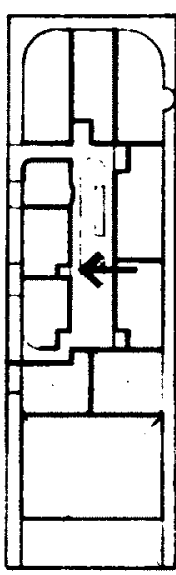

LEVEL 2 (1:1000)
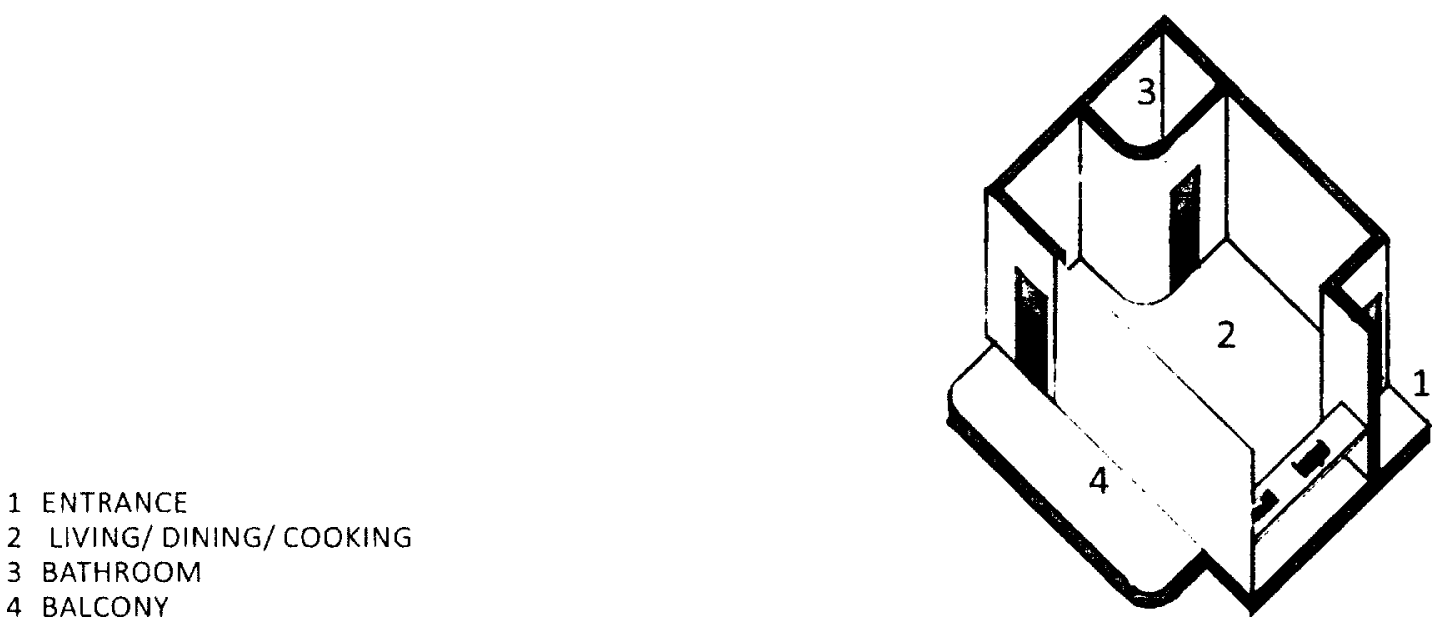
U N T

HO M E F O R

A C H I E V I N G MAXIMUM DISTANCE W I T H I N MINIMUM DISPLACEMENT

A THREE-STORY UNIT WITH THE ONLY SPIRAL STAIRCASE IN THE BUILDING IS FOR THOSE WHO LIKE TO ATTAIN ENOUGH STEPS PER DAY. IT TAKES THE SMALLEST FOOTPRINT, YET ACQUIRES THE GREATEST TRAVELLING FOOTSTEPS. A LOT OF WALKING AND WATER INTAKES ARE THE BEST TO START YOUR BUSY DAY

THERE IS A SAYING THAT GOES: THE BEST SHORTCUT IS TO TAKE A LONG ROUND BOUND.

- (REFER to the following SCENE ON WALKING FOR DETAILS.
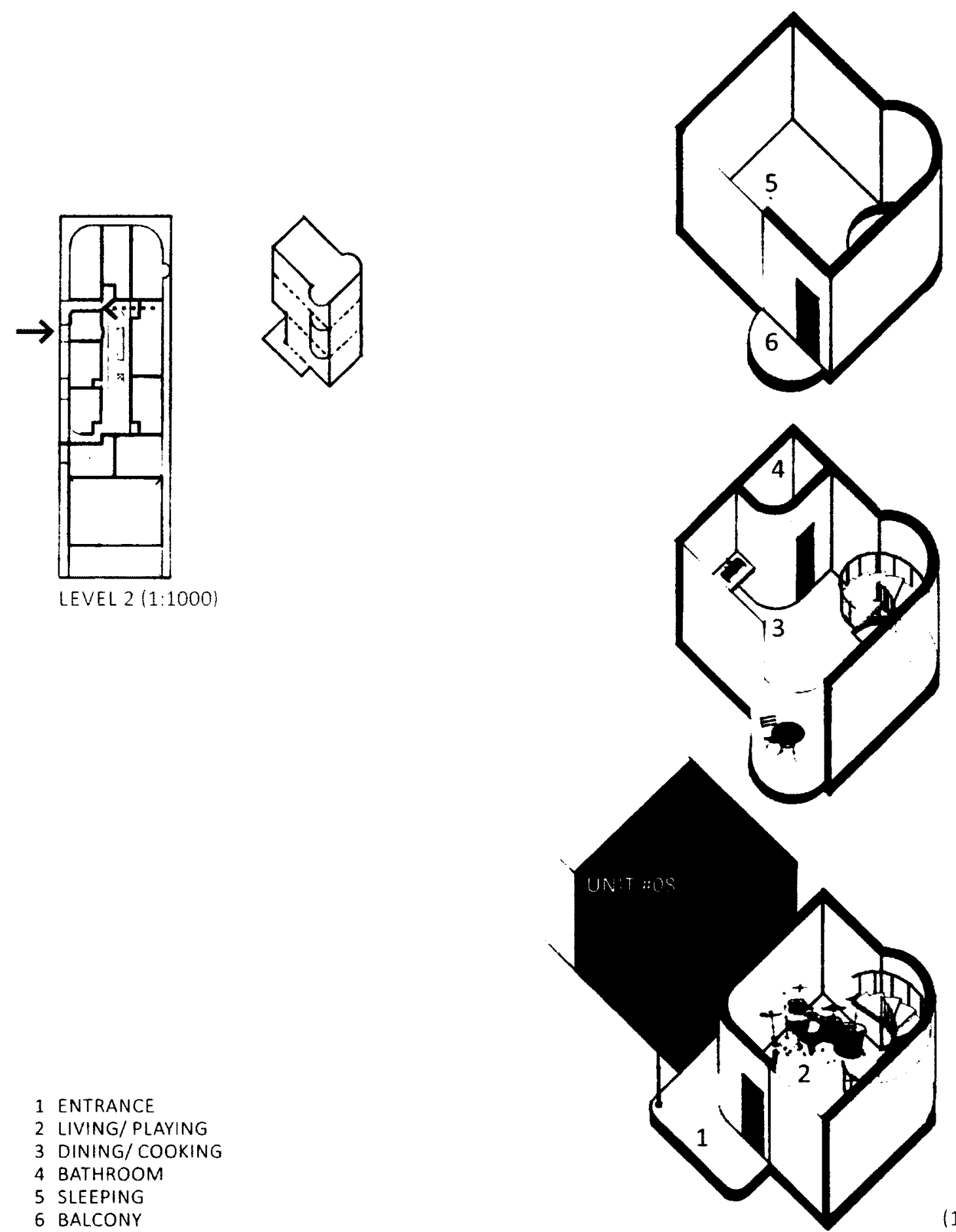

$(1: 200)$ 
$\begin{array}{llllll}T & A & K & \text { I } & \mathbf{N} & \mathbf{G}\end{array}$ $\begin{array}{lllllll}A & S & T & R & O & L & L\end{array}$

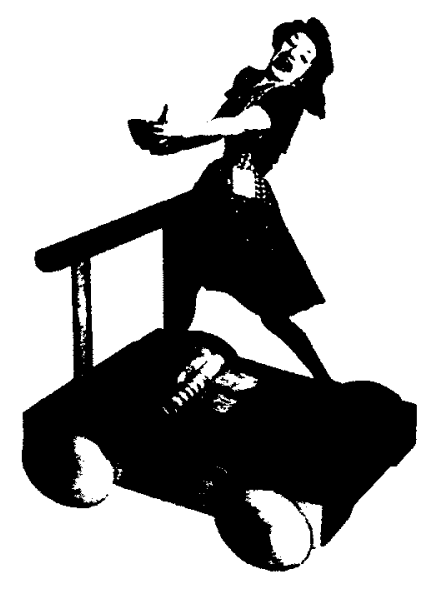

TAKE A STROLLI

HOUSEWIVES TAKING A STROLL WHILE DOING THEIR CHORES. SHE TAKES TIME COOKING, TASTING, EXPERIMENTING CREATING DIGESTIVE MEALS HAPPY HUSBANDS, HAPPY CHILDREN, HAPPY MOTHERS AND WIVES

\section{TAKE A STROLL II}

HUSBANDS TAKING A STROLL BEFORE WORK, TO WORK, DURING WORK, AFTER WORK. HE TAKES TIME TO DIGEST BEFORE RUSHING TO THE DOOR. IN THE MEANTIME, DOA AITTLE CROSSWORD PUZZLE OR SUDOKU WARM UP THE BRAIN. IT WILL HELP HIS MOOD AND METABOLISM.

\section{TAKE A STROLL THROUGH YOUR MIND \\ TEMPTATIONS. EXCERPT.}

Take a stroll through your mind

You'll be surprised at what you might find

Seems like every monday morning I've got the blues

And every tuesday I get some bad news

Wednesday worse cause I ain't got a dime to my name

I done worked so hard all week

Thursday my body just racked with pain

Here come the good part

Friday the eagle flies and so do I

I wonder if you hear me when I say

The eagle flies on friday and so do I

Take a stroll through your mind

You'll be surprised at what you might find
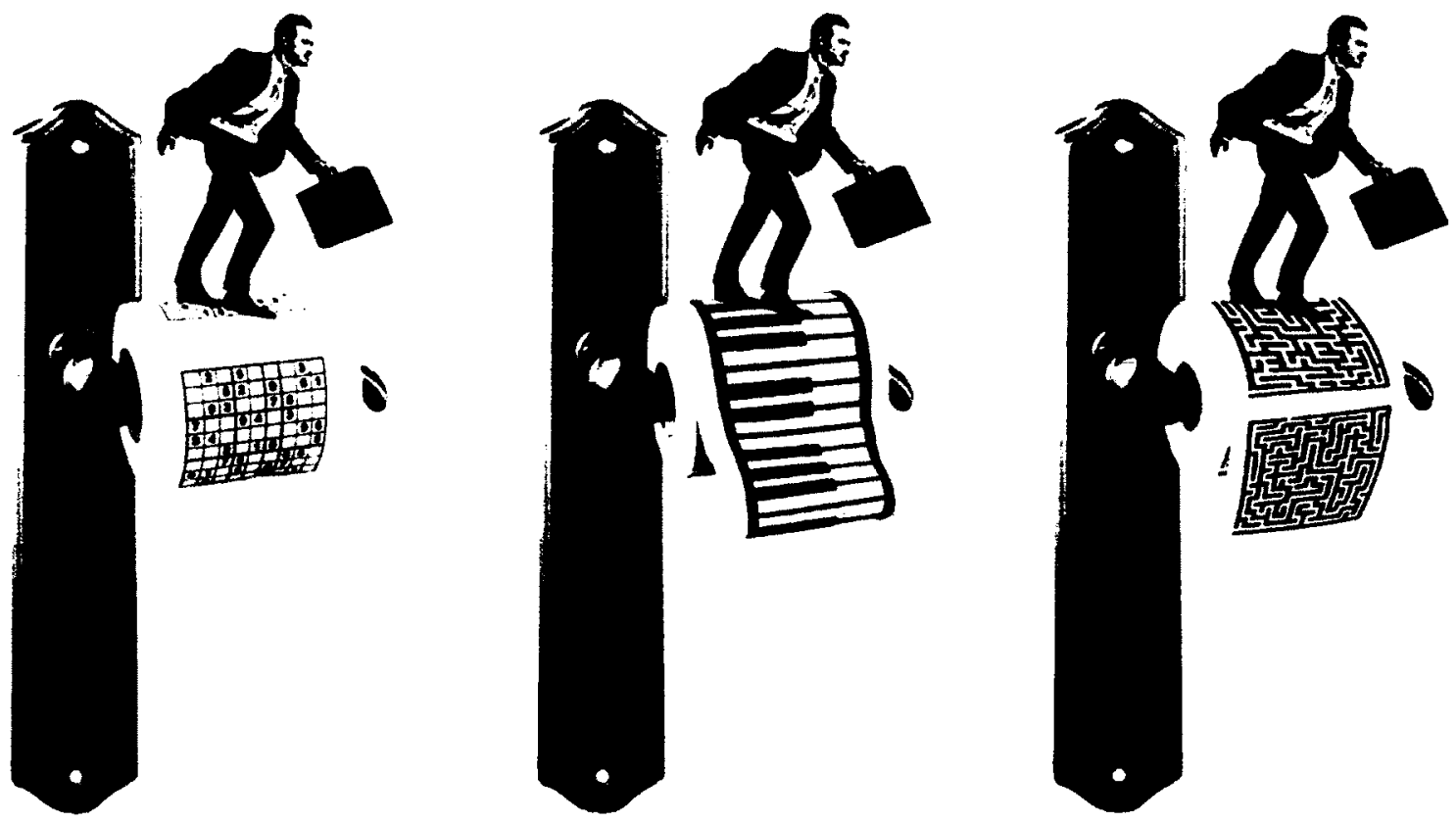
UN I T \# 08

$\begin{array}{llllllllll}H & O & M & E & & & F & O & R \\ S & M & O & K & E & R & S\end{array}$

THIS CORNER UNIT FEATURES TWO TINY BALCONIES ENOUGH TO SQUEEZE COMFORTABLY ONE, TWO OR THREE SMOKERS FOR SMOKING SMOKERSLIKETHE SMOKING. SMOKERS LIKETHE
INTIMATE CONVERSATIONS AND/OR BEING ALONG AND ISOLATED. THE (1X1)M ${ }^{2}$ VOIDS ALLOW THE CROWD TO KEEP THEMSELVES WARM IN THE WINTER IN THEIR LIGHTLY THERMAL SMOKING GOWNS.
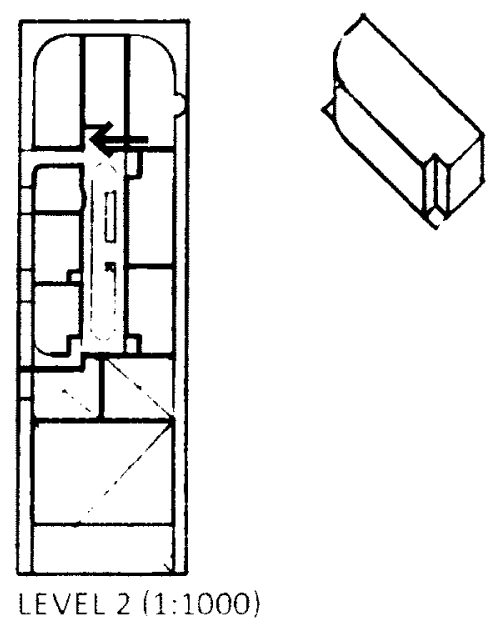

3 DINING/COOKING

4 BATHROOM

5 SLEEPING

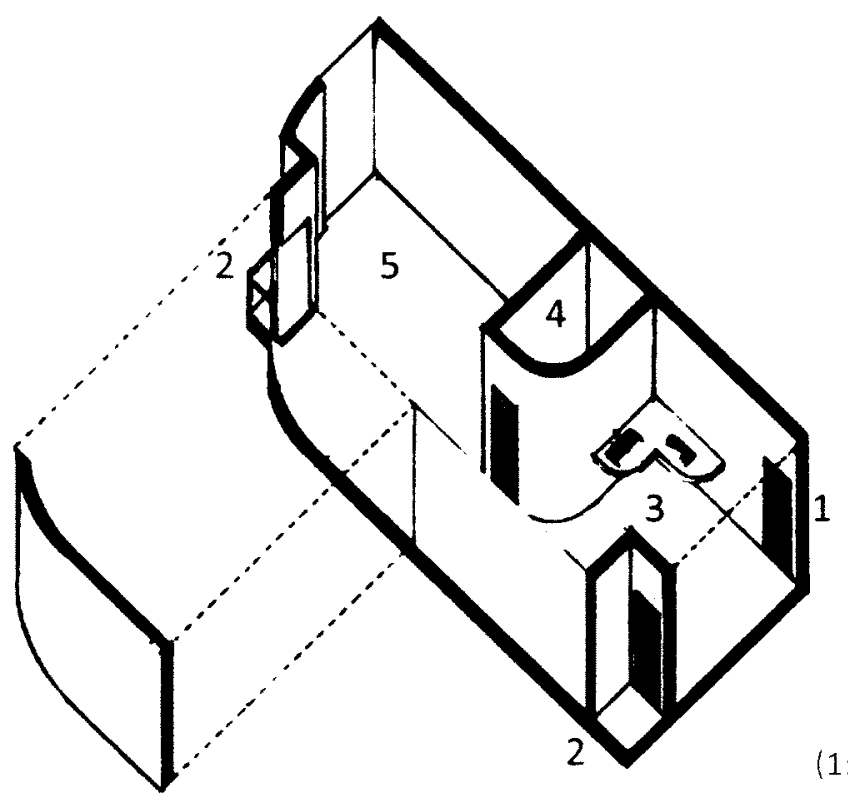

$(1: 200)$ 


\section{UN T \# $\mathbf{T} 9$ \\ H O M E FO R T I D Y P E O PLE}

THIS UNIT IS FOR THOSE WHO LIKE THE CLEAN MODERN WHITE ROOM WITH NOTHING ON THE SURFACE, OR FOR THOSE WHO SIMPLY LIKE TO EMPTY THEIR ROOM AND EMPTY THEIR ROOM AND
MIND TO MEDITATE. THE CENTRAL MULTI-USE SQUARE FOLDS AND UNFOLDS INTO A DINING TABLE, A TATAMI STAGE, AND AN EMBEDDED BED, GOOD FOR DEEP DIVING INTO DREAMS. THE BOTTOM HALF PART OF THE WALL FACING THE REAR FACADE CAN BE FOLDED DOWN TO FORM A LANDING. KITCHEN SET CAN BE INSTALLED WITHIN EITHER SIDE OF THE LONG WALLS UPON YOUR REQUEST.
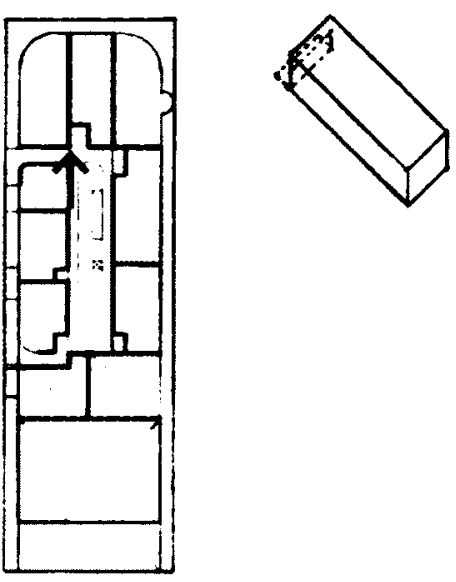

LEVEL 2 (1:1000)

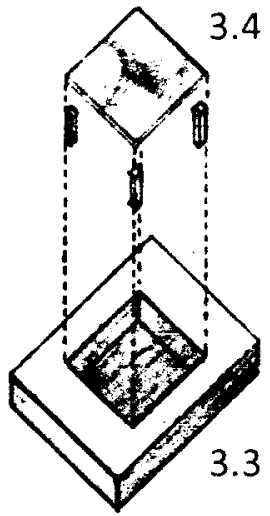

ENTRANCE

2 BATHROOM

3.1 STORAGE

3.2 BED

3.3 TATAMI STAGE

3.4 FOLDABLE TABLE + LEGS

4 FOLDABLE COPPER DECKING 
UN I T \#10

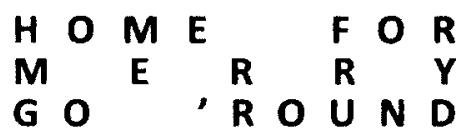

CIRCLES ARE PRACTICAL. YOU GET A FULL PANORAMA $360^{\circ}$ MOTION AROUND THE MECHANICAL CORE. NO

EDGES OR CORNERS THAT INTERRUPT OR INTERFERE WITH YOUR FANCY MOVES. IN THE OPEN SPACE, YOU CAN HANG A MOSQUITO NET, A

PROJECTOR, A DISCO BALL OR INSTALL A ROUND POOL TABLE (REQUIRES SKILLS TO DEFLECT A CURVED SURFACE ON ANOTHER CURVED SURFACE) OR A MERRY-GO-'ROUND. CIRCLES PROVIDE INFINITY OF FUN.
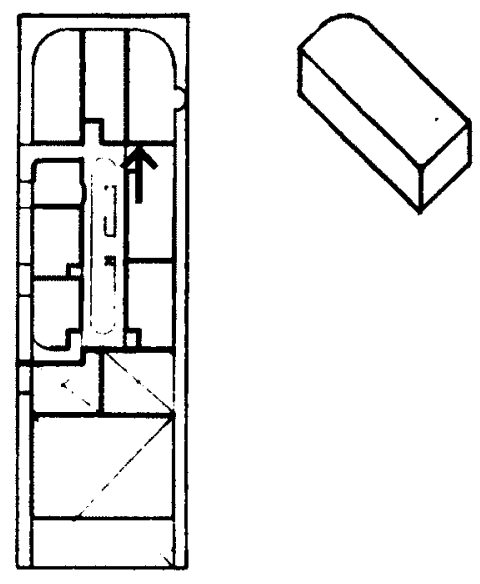

LEVEL 2 (1:1000)
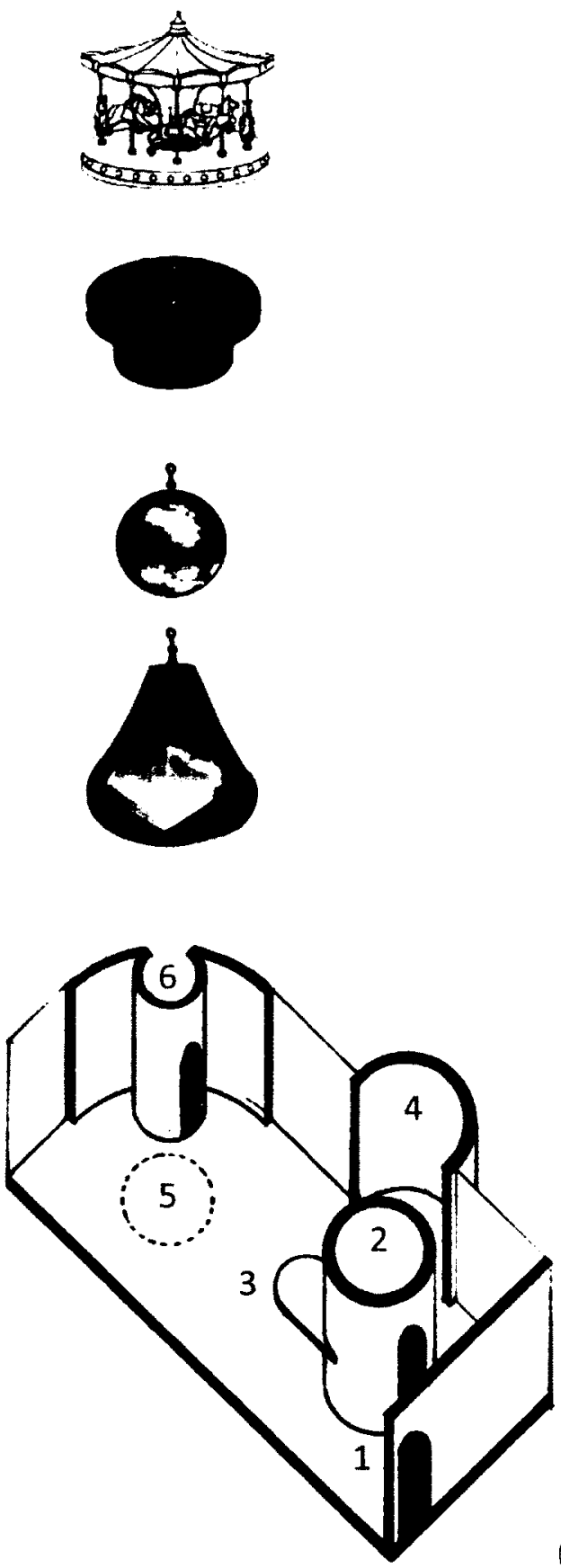
$U N \mid T \quad \# 11$

HOME FOR

MEDIAN STRIP

$L \quad O \quad V \quad E \quad R \quad S$

A RECTANGULAR UNIT DIVIDED IN HALVES, IS PARTED BY A MEDIAN STRIP OF GRAVEL, A) FOR PLANTING, AND B) FOR DISTINGUISHING SERVER AND SERVED ZONES. THE MEDIAN STRIP IS AN INDOOR COURTYARD WHICH CALMS YOU DOWN WHEN YOU ARE ABOUT TO RUSH THE SERVING WORKS INTO BEING SERVED EXPERIENCES,

AS YOU CROSS OVER BACK AND FORTH FROM ONE ZONE TO ANOTHER.
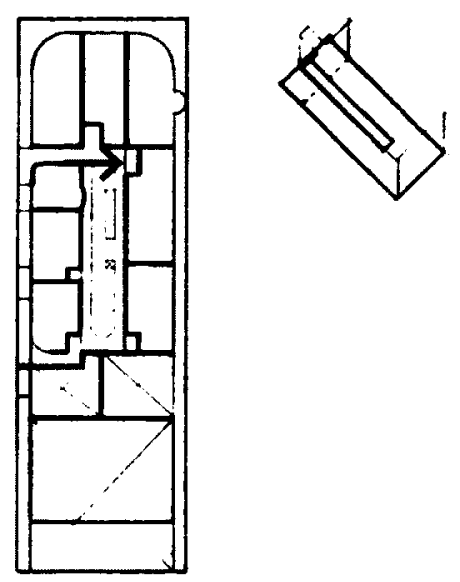

LEVEL 2 (1:1000)

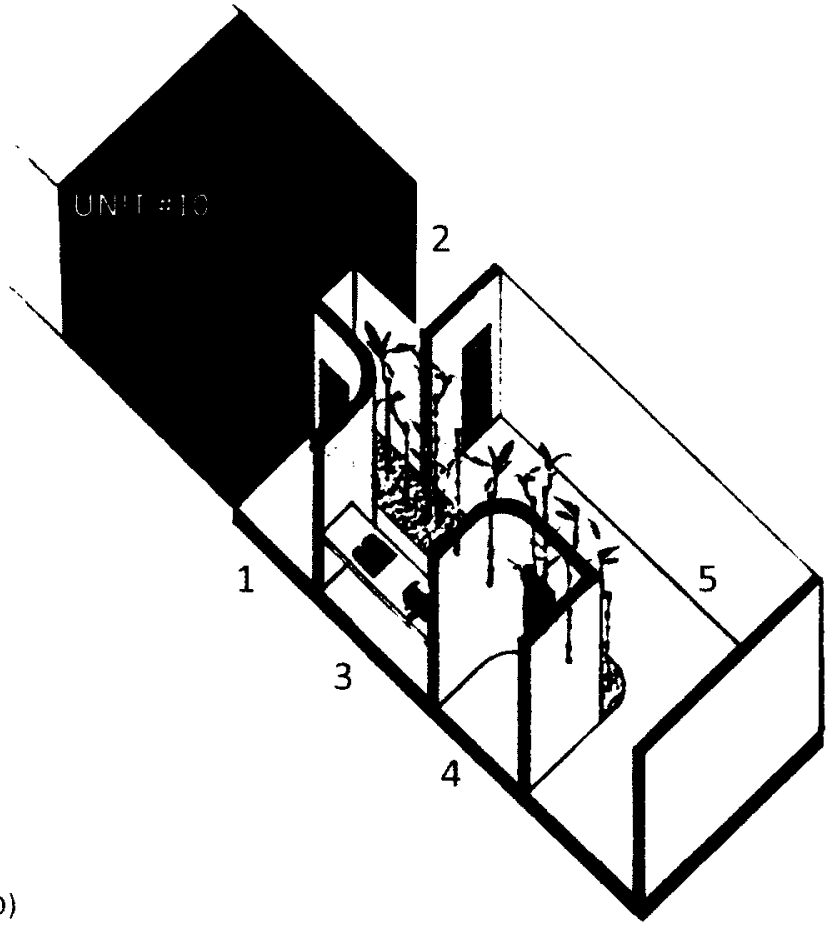

1 ENTRANCE

2 BALCONY

3 COOKING (SERVER)

4 BATHROOM (SERVER)

5 DINING/LIVING/SLEEPING/PLAYING (SERVED) 
U N T \#12

H O M E F O R DROPPED-CEILING L $\quad O \quad V \quad E \quad R \quad S$

NOBODYLIKESCHEAPPLASTIC DROPPED CEILING ACOUSTIC PANELS. BUT WE COULD ALL BE DROPPED HANGING SWINGING CEILING LOVERS. THE CRAWL SPACE ABOVE
THE CEILING IS AS USEFUL AS ITS BACK SIDE FACING THE MAIN LIVING SPACE. IET'S TRY GROWING GRASS ALONG GRAVITY, STARTING WITH AN ACCESSORY STOOL FOR DROPPED GRASS CEILING FOR CATS.
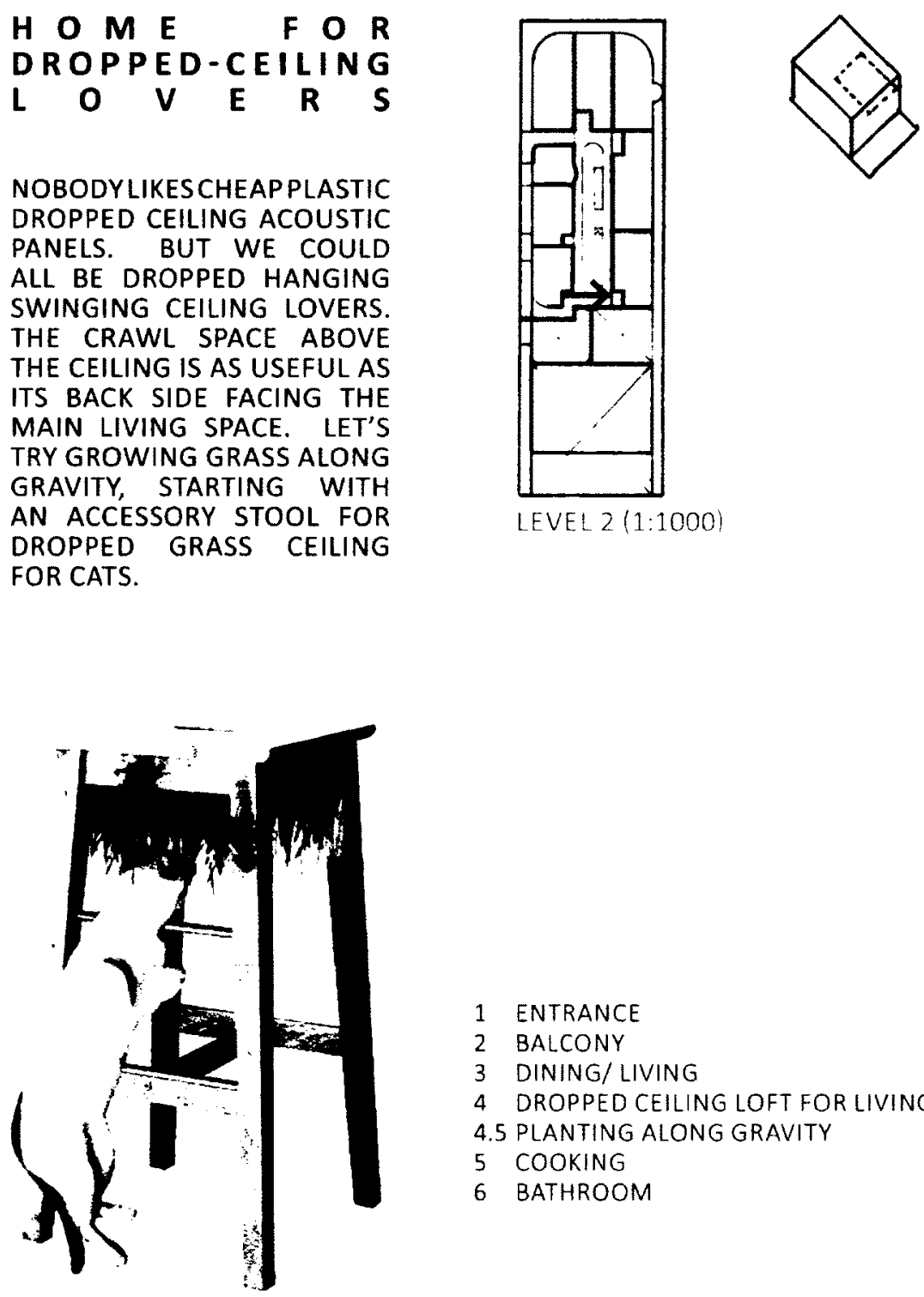

1 ENTRANCE

2 BALCONY

DINING/ LIVING

DROPPED CEILING LOFT FOR LIVING/SLEEPING/PLAYING

4.5 PLANTING ALONG GRAVITY

5 COOKING

6 BATHROOM

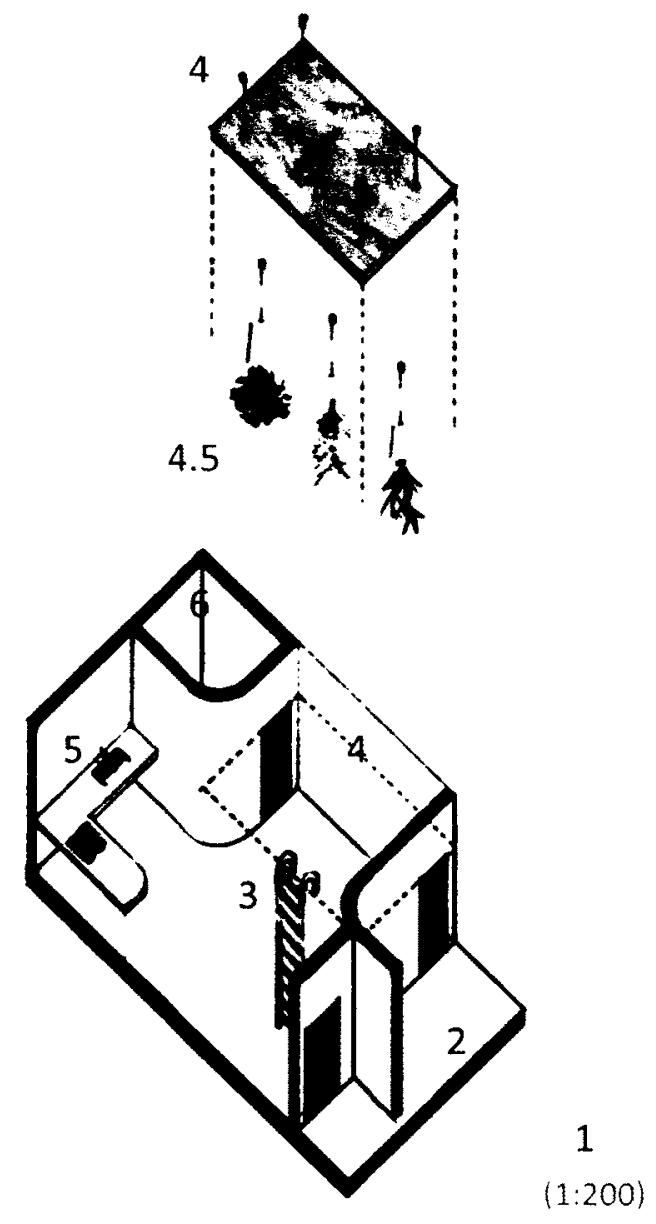


U N I T \#13

H O M E F O R

$\begin{array}{lllllll}A & R & T & 1 & S & T & S\end{array}$

$M$ I $N$ I M A L IS T S

THE SMALLEST UNIT IN THE

BUILDING FOR STUDIO USE.

A SINGLE SIMPLE OPEN SPACE

FOR YOUR CREATIVE USE.

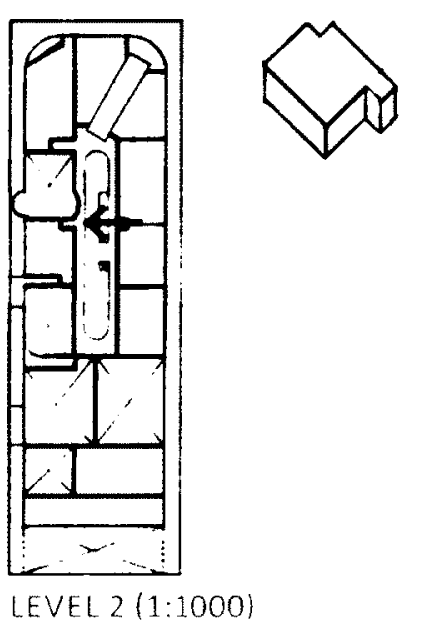

1 ENTRANCE

2 BATHROOM

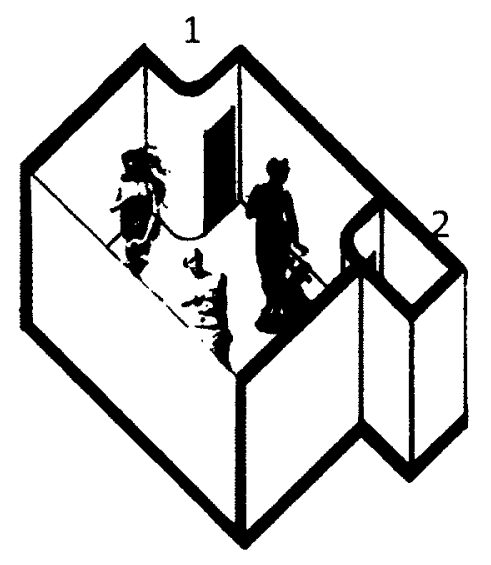

$(1: 200)$ 
U N I

HO M E F O R MULTI-PERSPECTIVALS

WALLS HAVE THICKNESSES, AND THEY CAN HAVE UNEVEN THICKNESSES FOR A) DYNAMIC IMBEDDED STORAGE, AND B) DYNAMIC PERSPECTIVAL VIEWS, LIKE A CUBIST PAINTER WOULD SAY, SURFACES CAN BE USED AS DEPTHS AS WELL. THIS UNIT IS FOR THOSE WHO ENIOY ODD ANGLES, AS IF HAVING A PAIR OF TRIANGULATED GLASSES THAT ENHANCES YOUR VISION TOWARD THE WORLD.
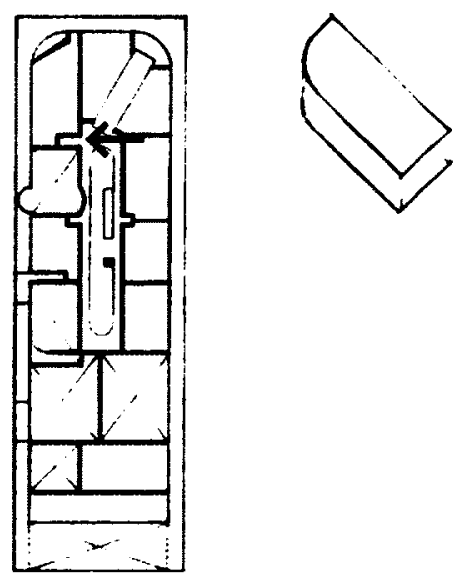

LEVEL $3(1: 1000)$

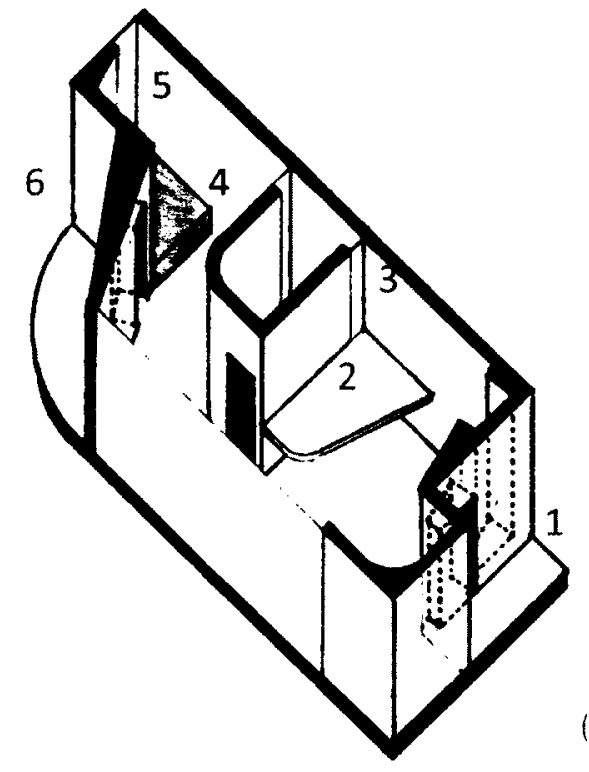

3 BATHROOM

4 SLEEPING

5 READING NOOK

6 BALCONY 
U N I T \# 15

HO ME FOR

G R E E N H O US E

F A $M \quad I \quad L \quad Y$

A REGULAR 2X (BED AND BATHROOM) FAMILY UNIT WITH A GREEN HOUSE PENETRATING THROUGH.

THE GREENHOUSE HOSTS

ENTRANCES TO ALL ROOMS

AND OUTDOORS AS WELL AS SPACES FOR PLANTING AND

FAMILY GATHERINGS. IT IS

WHERE CHILDREN CAN LEARN

HOW TO RESPECT SEMI-

PUBLIC SPACES AND WHERE

ADULTS CAN SUPERVISE

CHILDREN'S LEARNING IN A

LIVELY ENVIRONMENT THAT

THEY CREATE TOGETHER.
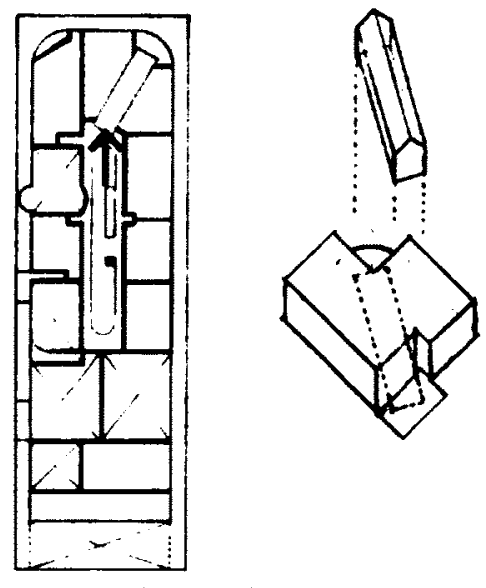

LEVEL 3 (1:1000)

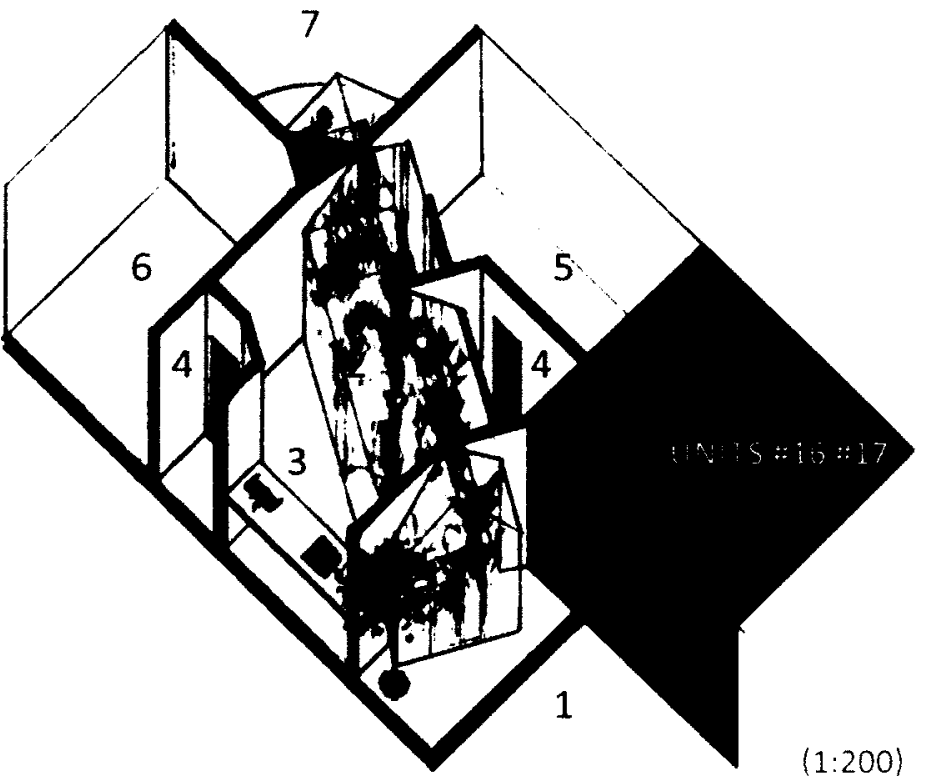

GREEN HOUSE/LIVING/ PLAYING/PLANTING/CIRCULATION

3 COOKING/DINING

4 BATHROOMS

5 MASTER BEDROOM

6 CHILDREN'S BEDROOM

7 BALCONY 
UNIT \#16 \#17

T W O - H A L V ES

H O M E FO R

C R E A T I V

PER F OR MER S

TWO-HALVES MAKE A WHOLE. THIS SET OF IDENTICAL AND MIRRORED STUDIO UNITS ARE FOR GROUPS OF CREATORS WHO LIKE TO COLLABORATE AND SHARE IDEAS. THE SPACE OF COURSE CAN BE SHARED.

THE FOLDABLE PANELS

AND EXTRA TRACKS (YOUR

CHOICE OF STRAIGHT LINE OR CURVED, OR A COMBINATION OF BOTH) CAN BE ORDERED

TO FORM ADVANCED SPATIAL

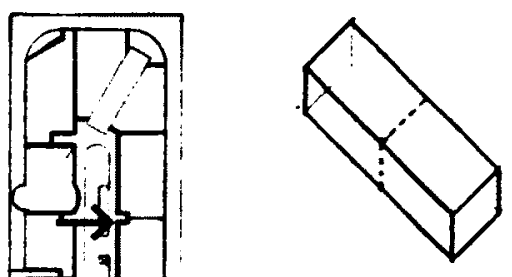
ARRANGEMENTS.

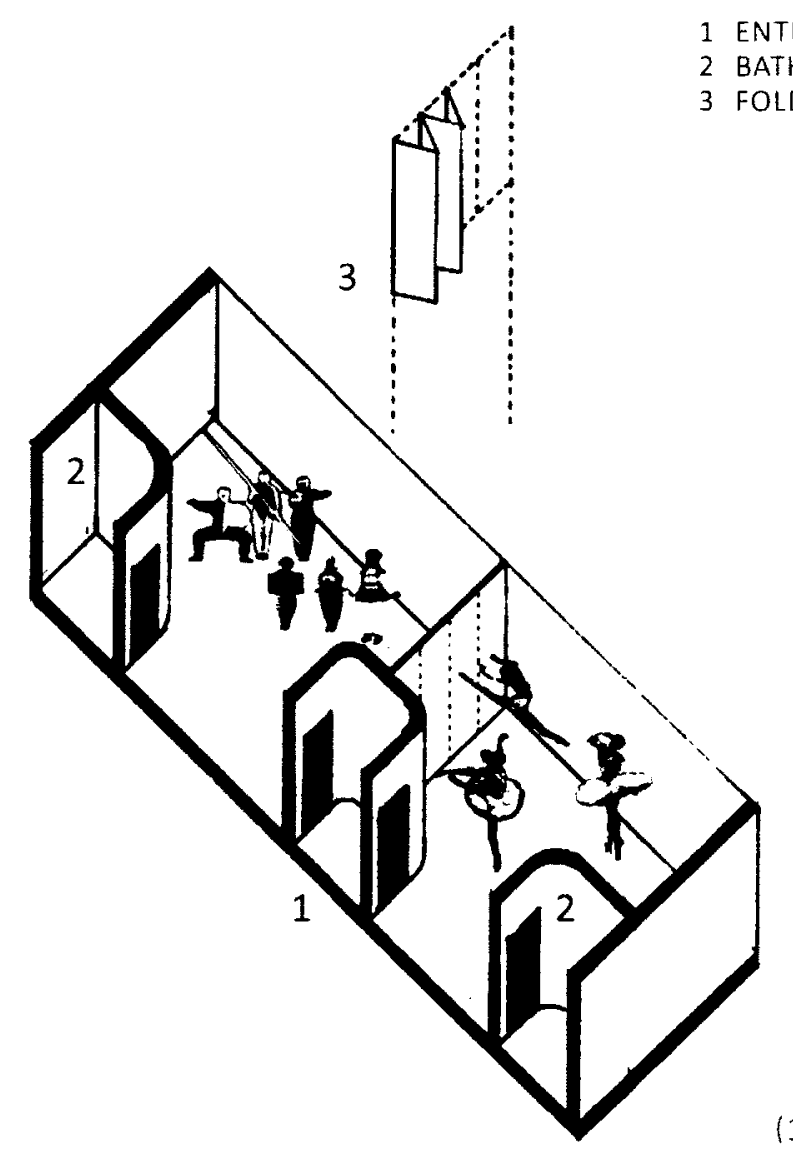

ENTRANCE

BATHROOMS

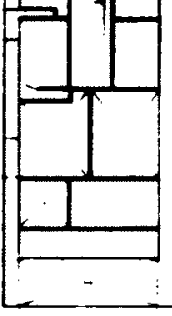

FOLDABLE PARTITION PANEL 
$\mathbf{U} \mathbf{N}$

\#18

HO M E

$F O R$

TRI-GENERATION

$F A M \quad L \quad Y$

THE LARGEST FAMILY UNIT OCCUPIESTHEMOSTCOMPLEX VOLUMES IN THIS BUILDING, THOUGH, THE INTERIOR

CONFIGURATION IS SIMPLE

AND STRAIGHTFORWARD

THERE ARE PLENTY OF ROOMS FOR THE CHILDREN TO PLAY

AND FOR THE ELDERLY TO

REST. THE BALCONY LOOKS

OVER TO THE PATIO OF THE HUB ON THE SECOND LEVEL, GETTING A GLIMPSE OF THE URBAN LIVELIHOOD, BUT WITH SUFFICIENT PRIVACY.
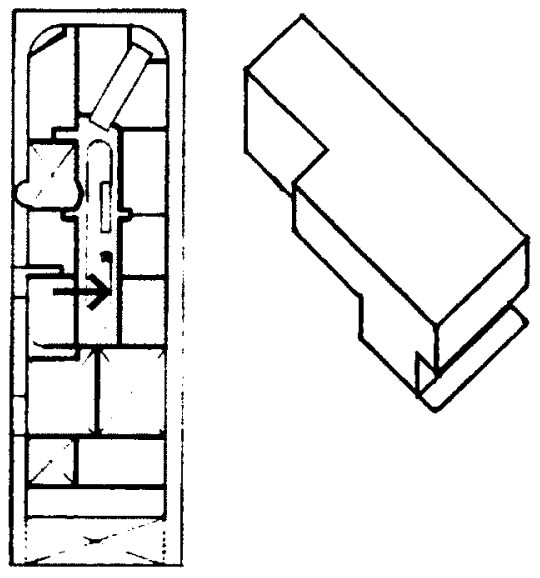

LEVEL 3 (1:1000)

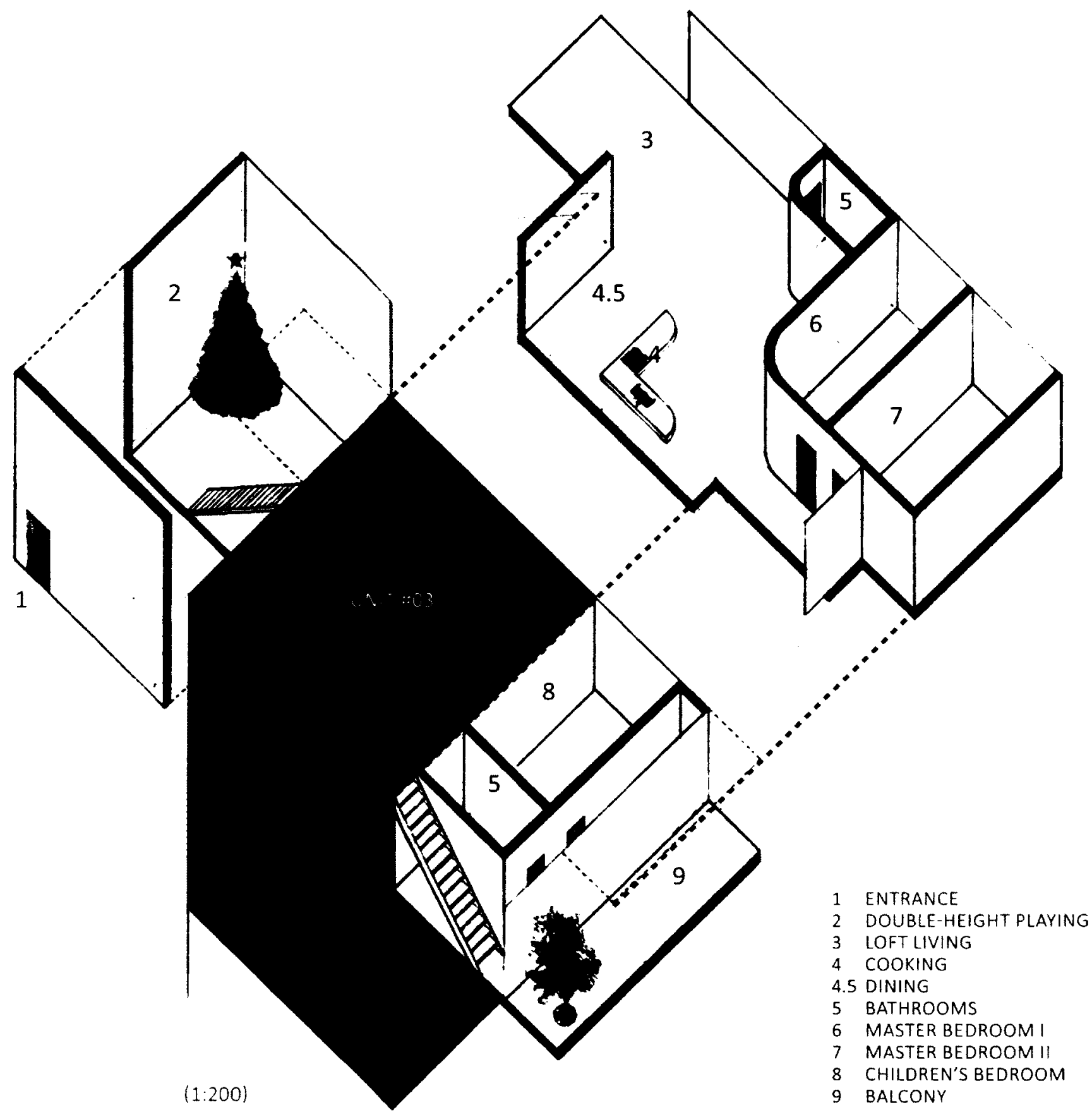


U N I T \#19

HOM E FO R

B I - G E NERATION

F A M I L Y

A SIMILAR FAMILY UNIT TO THE PREVIOUS BUT ONLY FOR ACCOMMODATING TWO GENERATIONS THE BALCONY ALSO LOOKS OVER TO THE PATIO OF THE HUB ON THE SECOND LEVEL, GETTING A GLIMPSE OF THE URBAN LIVELIHOOD, BUT WITH SUFFICIENT PRIVACY.
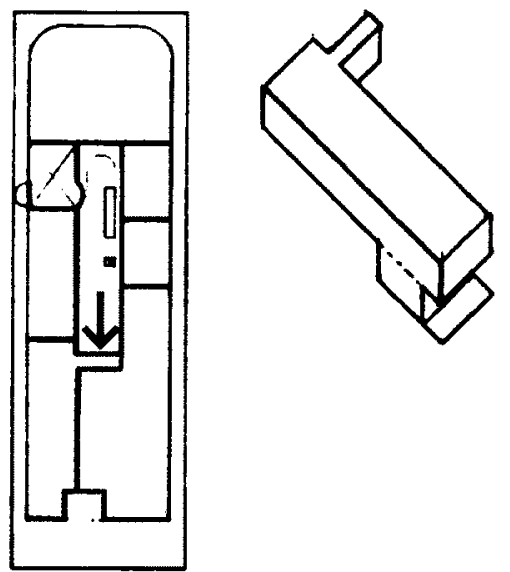

LEVEL $4(1: 1000)$

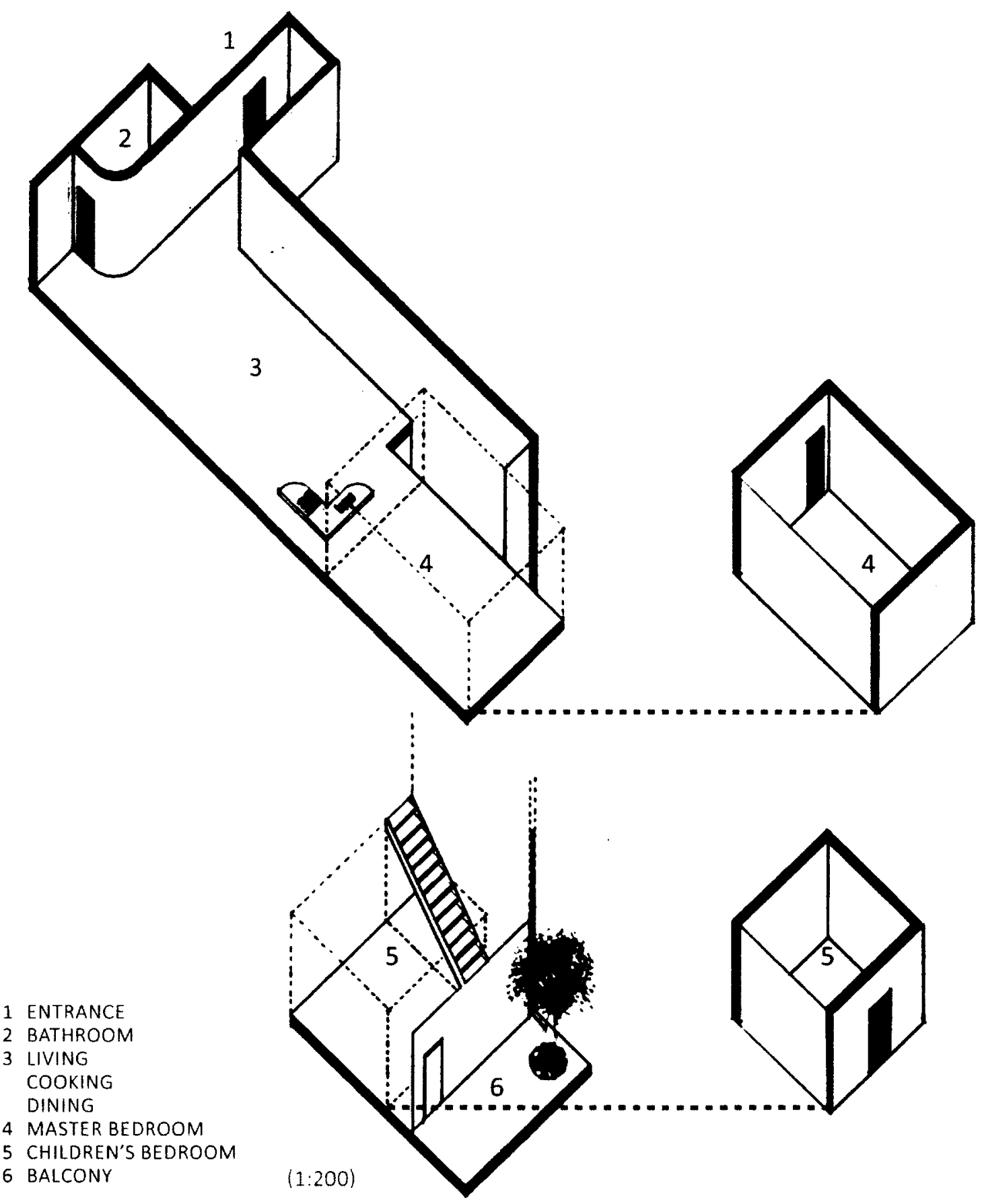


$\begin{array}{lll}\mathbf{U} & \mathbf{T} & \mathbf{2} 0\end{array}$

H O M E FOR ROMANTICISTS $\&$

ASTRONOMERS

FOR DREAMERS AND THOSE WHO LIKE TO HOLD THEIR WHO LIKE TO HOLD THEIR
HEADS HIGH AND SET THEIR GOALS HIGH WHETHER YOU JUST WANT TO GAZE THE STARS FROM AFAR OR THE STARS FROM AFAR OR
EXAMINE THEM CLOSELY, THIS UNIT FEATURES TWO SKYLIGHTS FOR A PERFECT SET OF PLANETARIUM PRT OF PLANETTED AT HOME. WITH NO DISTRACTION FROM THE CITY'S NEON LIGHTS, ONE VIEW FINDER SITS ABOVE THE LIVING/DINING AND ANOTHER ABOVE THE SLEEPING AREA NOT TO MENTION IT COMES WITH A NATURAL WAKE-UP CALL FROM THE SUN

- (REFER TO THE FOLLOWING SCENE ON STAR GAZING FOR DETAILS.)
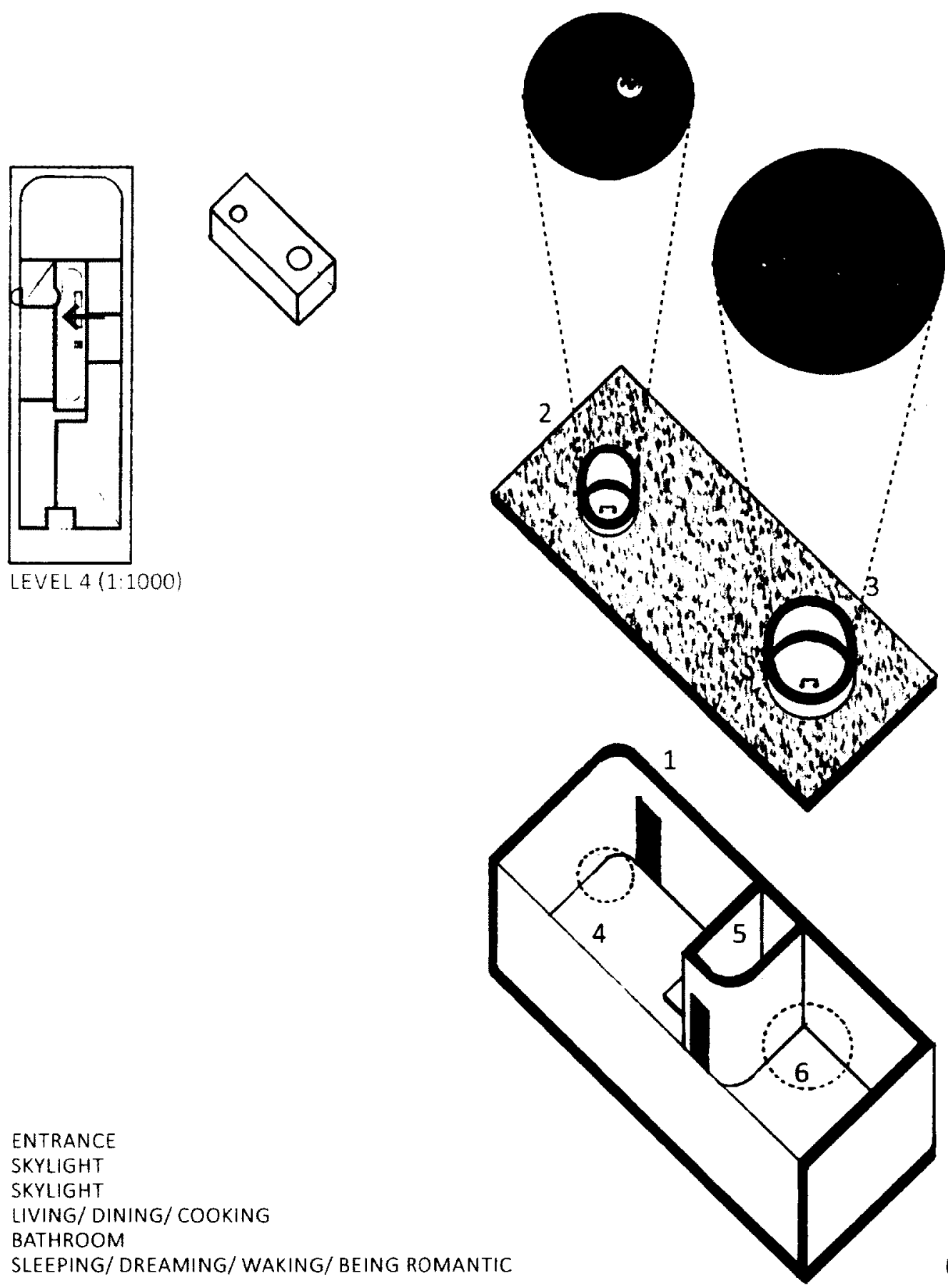

$(1: 200)$

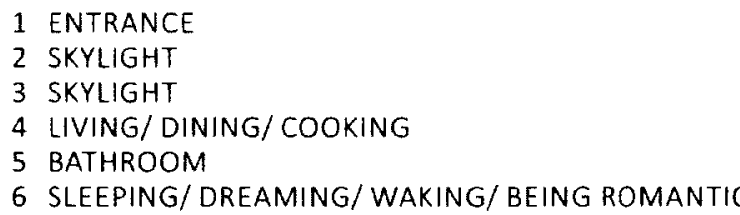




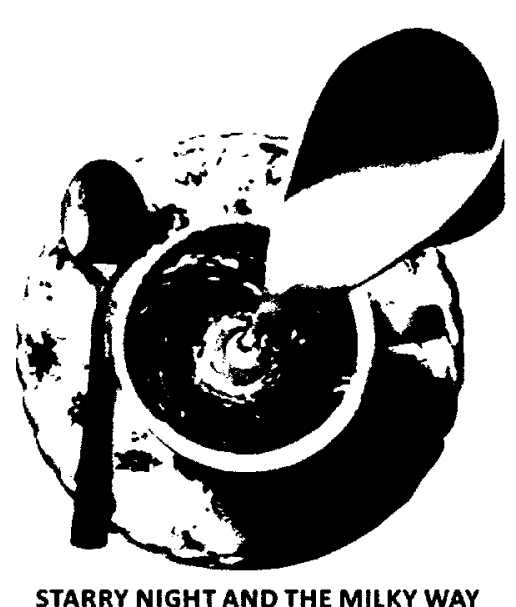

STARRY NIGHT AND THE MILKY WAY

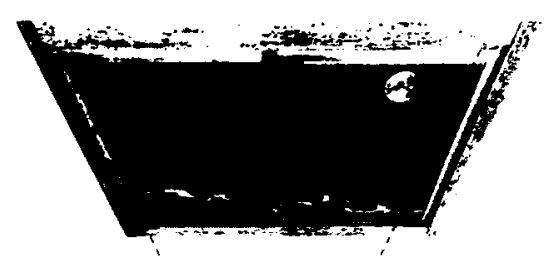

CAMERA ÖBSCURA NIGHT WATCHING

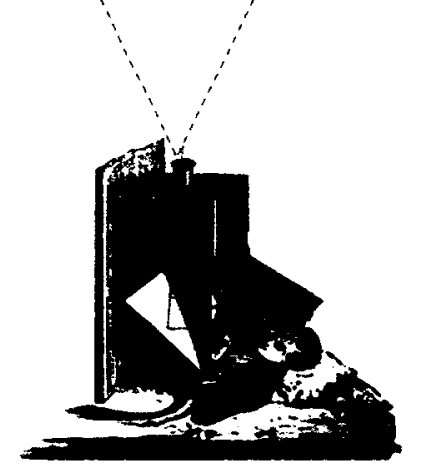

When I was just a little girl, I would get scared of the dark and the shadows in my bedroom when I go to sleep. So then Daddy would put a pot full of water beside my bed, and tell me to take a look into it... And there, it shines the moon, twice as bright, capturing and releasing its light from above and below. I would watch the moon swim. I would poke her sometimes, to see her giggle. I would connect the stars to make a picture. Then eventually I would fall asleep.... diving deep into my own little pot-planetarium.

Still today, I would pause and look up to the indigo sky, searching for the colourful stars, red green orange purple, and try to guess the percentage fullness of the moon. It is quite rude of city's neon light parade to interfere with natural night light, but it does not mean that light pollution overwrites the natural. The moon and stars are there to see, if you look.

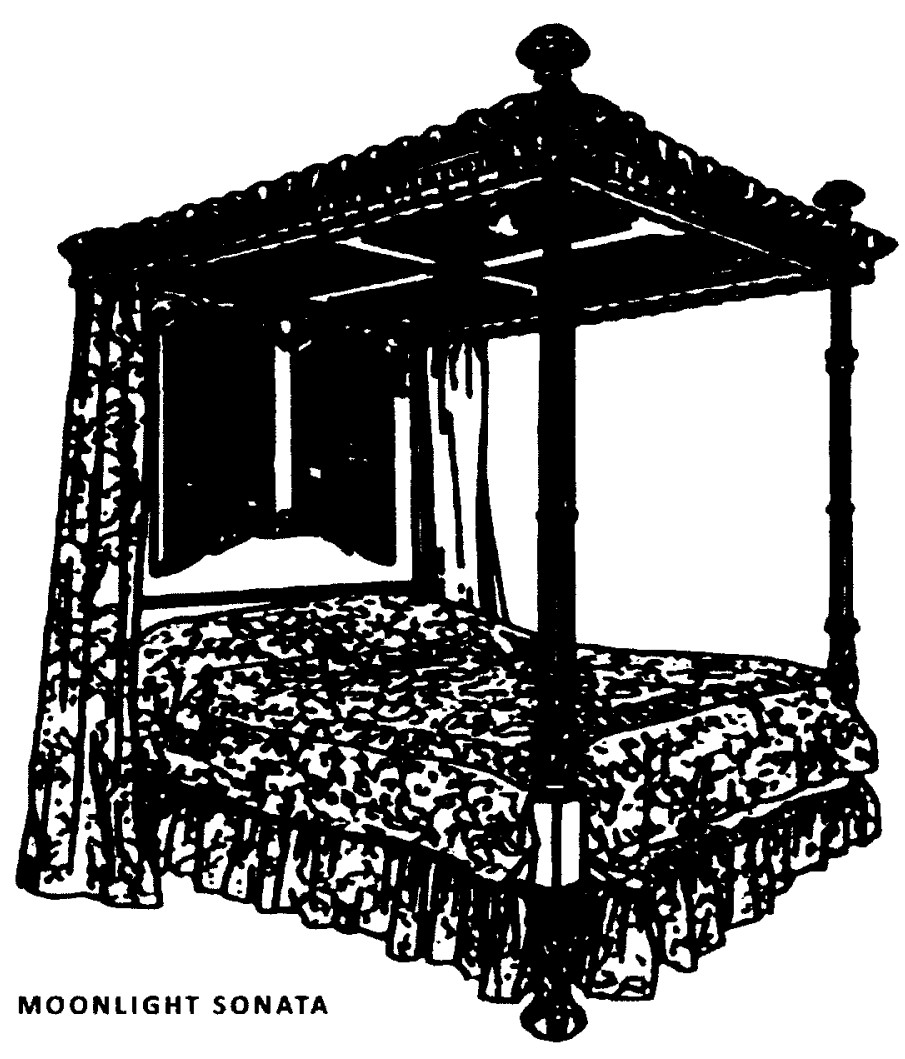


U N I T \# $\mathbf{2}$

HO M E FOR C A T LOVERS

CAT LOVERS CAN LIVE LIKE THEIR CATS, AND CATS WANT TO LIVE LIKE THEIR LOVERS. THE SQUARE ZEN

GARDEN IN THE CENTRE IS A SANDBOX FOR YOU TO PLAY SANDBOX FOR YOU TO PLAY TO POOP AND PLAY. MAKE PRETTY PATTERNS. DRAW THE UNIVERSE. THE UPPER LANDING PLANES ARE FOR YOU AND YOUR CATS TO HOP ON, ROLL AROUND AND SUNBATHE. THEY ARE CARPETED FOR YOUR SOFT TOUCH AND YOUR CAT'S CLAW GRIPS
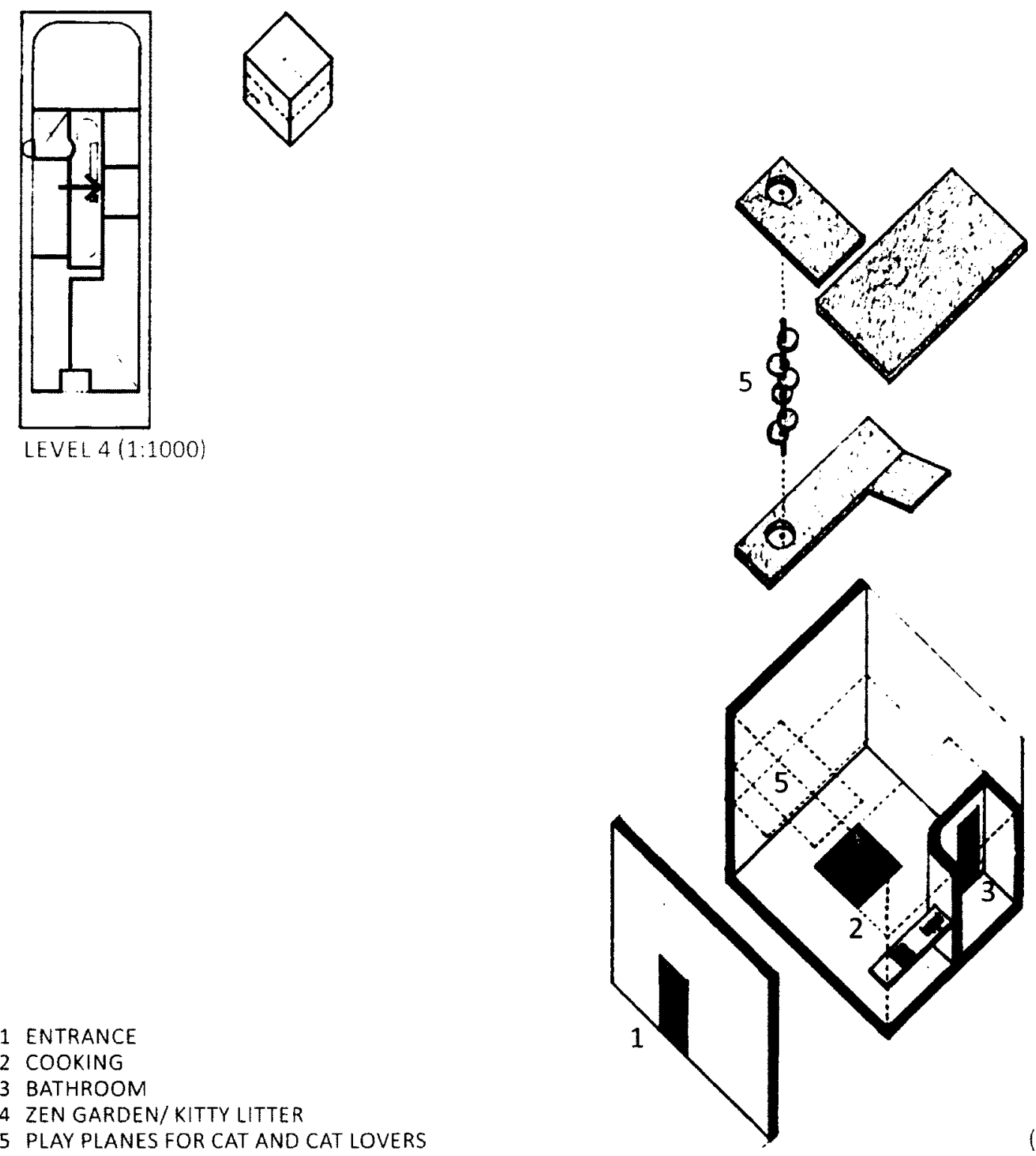

$(1: 200)$ 
UN T

HOM E F O R $\begin{array}{llllllll}S & L & P & E & D & R & O & O \\ L & O & V & E & R & S\end{array}$

IF YOU DON'T LIKE FLAT CEILINGS OR DROPPED CEILINGS THEN YOU CAN HAVE A SLOPED CEILING AND ROOFING TO BRING BACK THE PLAYING-IN-THEATTIC OR PITCHING-A-TENT ATMOSPHERE FROM YOUR CHILDHOOD. THE UNIT GIVES YOU, ON THE ONE HAND, AN INTIMATE PRIVATE RESTING SPACE, AND ON THE OTHER, A SPATIAL VERTICAL SURFACE TO EXHIBIT YOUR
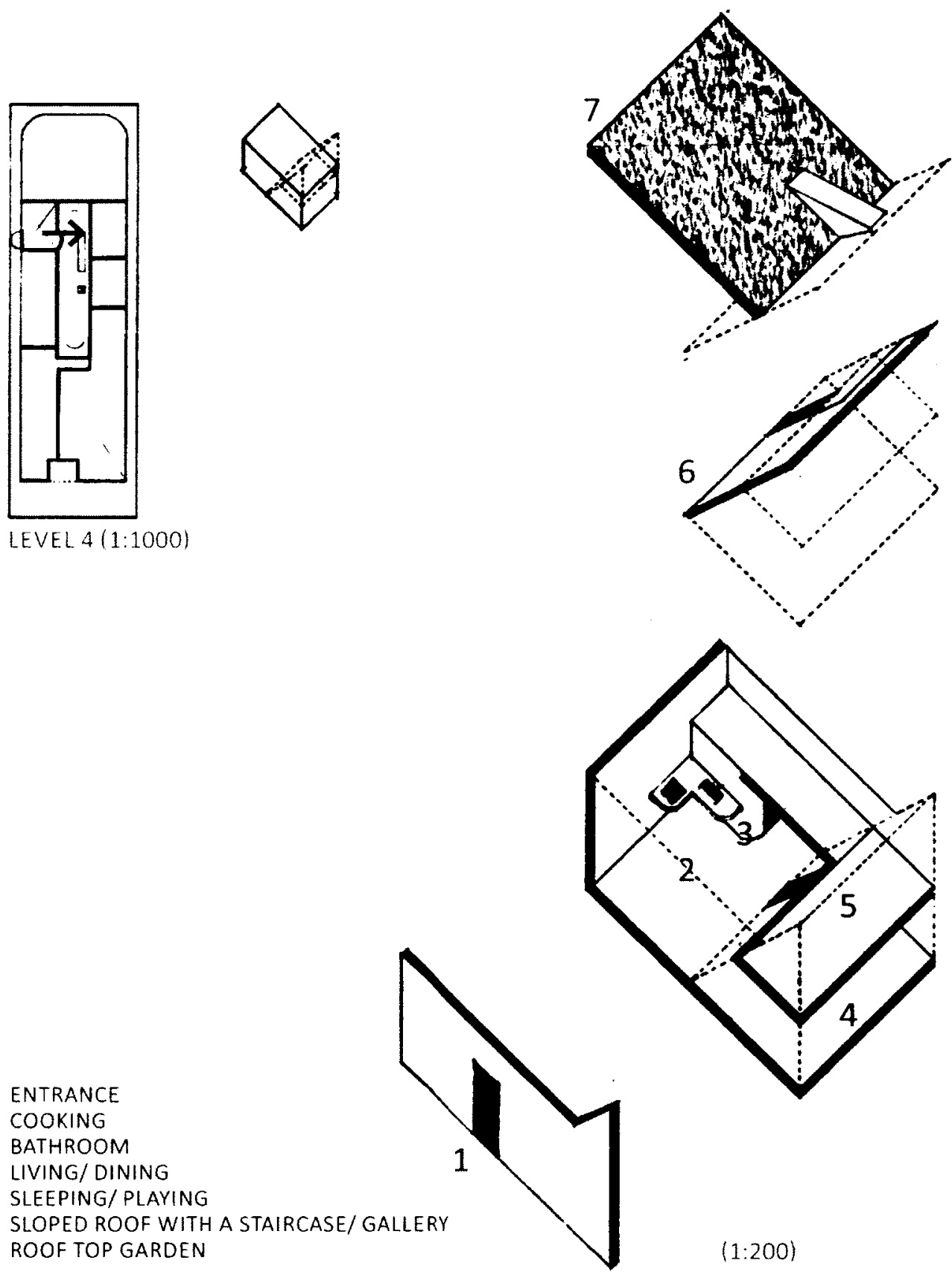
WORKS AND MEMORIES. 
\begin{tabular}{l|l}
$\mathbf{N}$ & $\mathbf{T} \mathbf{2} 3$
\end{tabular}

HO M E FOR

P R O - S O C I A L $\&$

A N T I-SOCIA L NE I G H B O UR S

WHETHER YOU ARE A SOCIALLY ENGAGING

INDIVIDUAL OR A SHY ONE,

THIS UNIT IS A MINIATURE

FORM OF THE HOUSE,

A COMMUNITY WITH A

CENTRAL CIRCULATION AND

GATHERING CORE. LAST BUT NOT THE LEAST, THE UNIT

IS AFFORDABLE AND CAN

ACCOMMODATE AN EXTRA

LARGE FAMILY AS WELL AS A

GROUP OF STUDENTS WHO

ENJOY SHARED LIVING. THE

NOISE LEVEL WOULD NOT

IMPACT THE REST OF THE

BUILDING AS IT IS ON THE

TOP LEVEL, AND AWAY FROM

OTHER FAMILY UNITS.
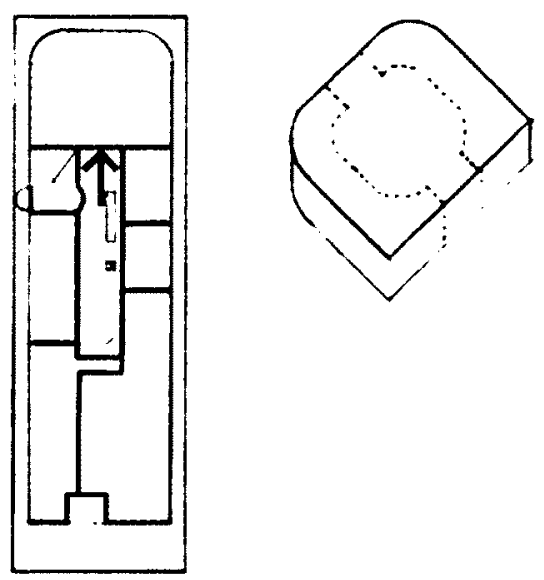

LEVEL $4(1: 1000)$

1 ENTRANCE

2 CLOSET

3 BATHROOM

4 COOKING

5 LIVING/DINING/GATHERING

6 BALCONY

7 BEDROOMS

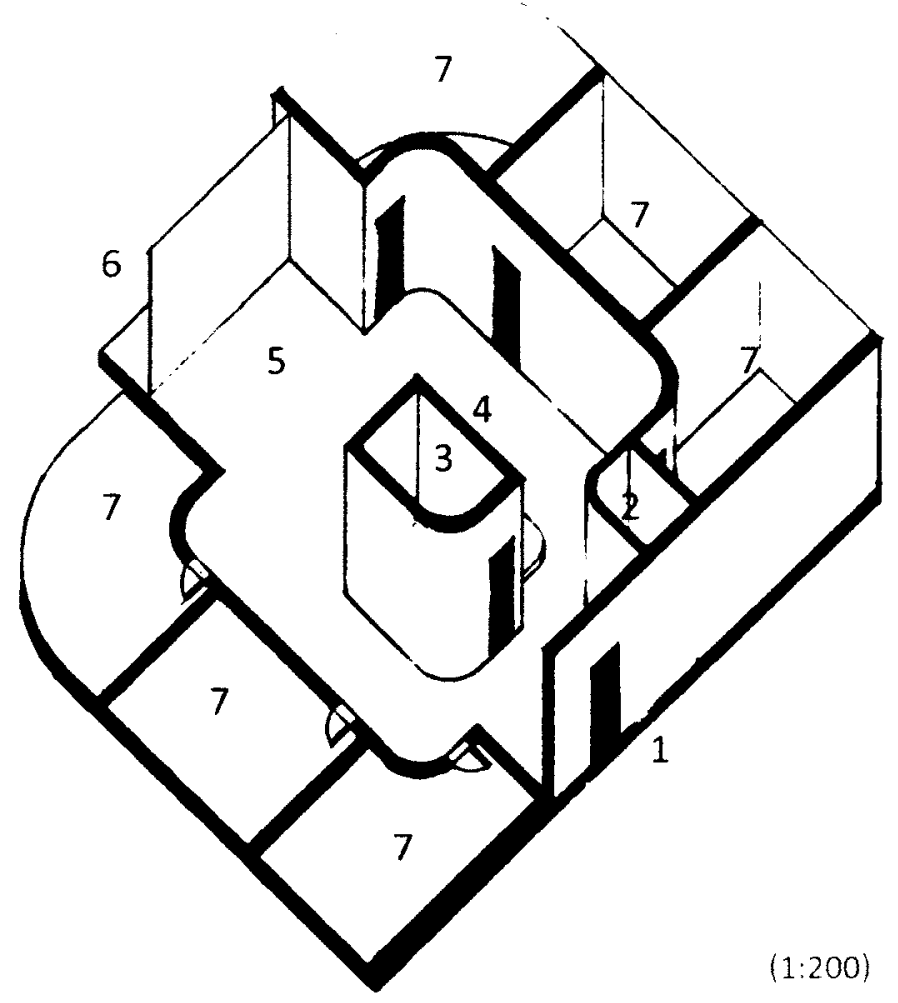




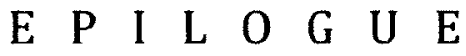

DINNER PARTY

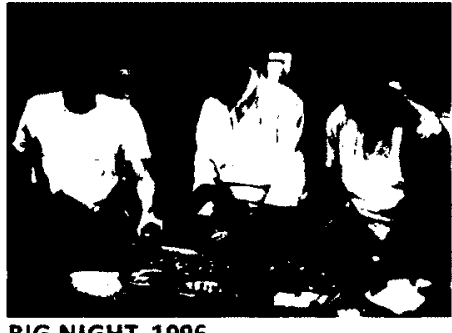

BIG NIGHT. 1996.
Thank you for your attention and participation in the HOUSE tour.

The night has fallen, and the curtain has drawn...

Yet the time is young...!

Let us celebrate our moment of Ma together.

You may sit again, or continue to sit, and meanwhile we can as well sing, swing, skip, stroll, skate...

You will be served with slow food, picked, prepared and presented by good hand and good heart.

The Big Night is all ours.

Remember to taste up and down, in and out, and all around, and there, more flavours are to be found.

Good dreams, good sense, and good vision can spin your life back into the kaleidoscope of brilliant colours.

It was my pleasure to host this event.

Thank you for your attention and support.

Stay well, until the next Visit.

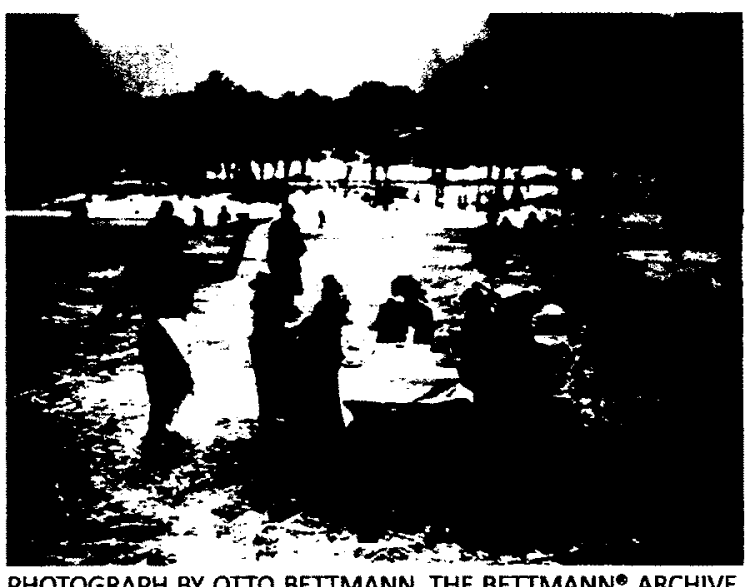

PHOTOGRAPH BY OTTO BETTMANN. THE BETTMANN* ARCHIVE, 
C O N C L U S I O N

The issues of: a) standardization in planning; b) building methodology aimed for profit over quality of performance; and c) lifestyles impacted by the high and low tides of the fast and vast running system questioned me to think about the very shintai relationship between the living body and built body. And I believe that the two actors, the living and built bodies, can come to a comfortable middle ground of shintai as one. By being aware of each body movement in accordance to the part of the built that comes in contact, the basics of actions can be amplified, turning the routines into a credited exercise. This simplifies housing planning and household gadgets back to corporeal dimensions and functions, without being reduced to just an open empty white box. By no means I meant to bring the digital and automatic system back to all manual, nor introducing inconveniences, it is only my intention to use our body and technological extensions in balance to achieve the best result in work, play, sleep and so on. Instead of thinking that we must live up to the external expectations, or expecting external forces to do everything for us, taking a step back and pause to think about it before rushing into automatic pre-programmed actions helps us regain senses and fitness. This way, buildings' transformation, both growth and decay, can accommodate innovations, new creations, as well as preserving the basics and traditions, not in separate directions as to one rushes forward and the other stays behind, but both coexisting on one time-line. 


\section{P O S T S C R I P T}

All the information I have given so far is nothing new but is what we already know or what we are familiar with, and that is precisely the point, where we tend to forget the basics and essentials. For building and living the present and future with memory of the past, we do not necessarily always need something new. The key to make better living is to take close look at the common sense and normal things around us and make best use of all. And only by first-hand experience of building moments can our senses and health be brought to fitter, happier and more productive level of conscious.

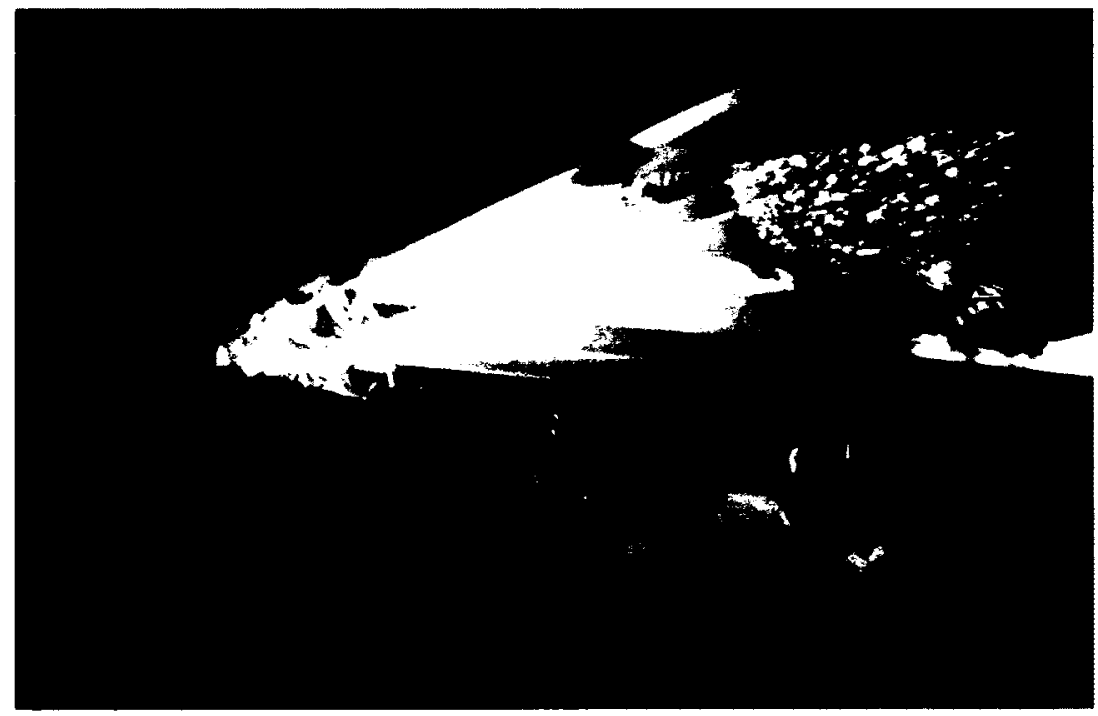




\section{B I B L I O G R A P H Y}

ALBERTO PEREZ-GOMEZ. BUILT UPON LOVE: ARCHITECTURAL LONGING AFIER ETHICS AND AESTHETICS. LONDON: THE IMT PRESS, 2006. PRINT.

CHERMAYEFF, SERGE, AND CHRISTOPHER ALEXANDER. COMMUNITY AND PRIVACY: TOWARD A NEW ARCHITECTURE OF HUMANISM. NEW YORK: DOUBLEDAY, 1965

FITCH, JAMES MARSTON. AMERICAN BUILDING: THE FORCES THAT SHAPE IT. NEW YORK: SCHOCKEN BOOKS. 1973.

FOSTER, HALL EDT. THE ANTI-AESTHETIC: ESSAYS ON POSTMODERN CULTURE. NEW YORK: THE NEW PRESS,1998

FRAMPTON, KENNETH.MOOERN ARCHITECTURE:ACRITICALHISTORY IONDON: THAMES \& HUDSON. 1992 FROMM, ERIC. ESCAPE FROM FREEDOM. LONDON: ROUTLEDGE

HONORE, CARL.IN PRAISE OF SLOW. TORONTO: KNOPF CANADA. 2004

JENCKS, CHARIES AND GEORGE BAIRD ED. MEANING IN ARCHITECTURE. NEW YORK - GEORGE BRAZIULR, INC., 1970.

MARCUS, CLARE C. HOUSE AS A MIRROR OF SELF: EXPLORING THE DEEPER MEANING OF HOME. CALIFORNIA: CONARI PRESS, 1995.

RADIOHEAD. FITTER HAPPIER.

RIESMAN, DAVID. ABUNDANCE FOR WHAT? NEW JERSEY: TRANSACTION PUBLISHERS, 1993

ROWE PETER G MODERNITY AND HOUSING. CAMBRIDGE:MIT PRESS, 1995.

RYBCZYNSKI WITOLO HOME:ASHORTHISTORY OF AN IDEA PENGUIN BOOKS CANADA LIMITED, 1986

SLESSOR, CATHERINE. CONCRETEREGIONALISM. LONDON: THAMES\& HUDSON, 2000

SOMMER, ROBERT. PERSONAL SPACE: THE BEHAVIOURAL BASIS OF DESIGN. NEW JERSEY: PRENTICE-HALLINC, 1969.

TZONIS, ALEXANDER. "PEAKS AND VALLFYS(BY ARCHITECTURE) IN THE FLAT (DIGITAL) WORLD" IN CULTURES OF DESIGN SYMPOSIUM BAUHAUS-UNIVERSTTAT WEIMAR, JUN 2006.

VIDLER, ANTHONY. THE ARCHITECTURAL UNCANNY: ESSAYS IN THE MODERN UNHOMEIY. LONDON: THE MIT PRESS, 1992.

WIUIAMS, RAYMOND. KEYWORDS: A VOCABULARY OF CULTUREAND SOCIETY. REVISED EDITION. NEW YORK: OXFORD UNIVERSTTY PRESS, 